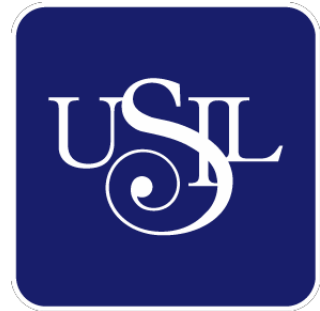

UNIVERSIDAD

SAN IGNACIO

DE LOYOLA

FACULTAD DE ARTES Y HUMANIDADES

Carrera de Arte y Diseño Empresarial

\title{
LA RECREACIÓN ICONOGRÁFICA DE LAS CULTURAS ANCESTRALES PERUANAS COMO PROPUESTA VISUAL PARA EL FORTALECIMIENTO DEL IMAGINARIO EN LOS JÓVENES DE 20 A 30 AÑOS DE EDAD
}

Tesis para optar el Título Profesional de Licenciado en Arte y Diseño Empresarial

JOSÉ LUIS PRÍNCIPE DE LAMA

Asesor:

Mtro. Rafael Vivanco Álvarez

Lima - Perú

2022 
A mis padres 


\section{Agradecimientos}

El presente trabajo de tesis expone un proyecto empresarial que se gestó cuando aún era estudiante de los últimos ciclos de la carrera de Arte y Diseño Empresarial de la Universidad San Ignacio de Loyola. Mi inclinación hacia la imagen corporativa y la ilustración fueron sustanciales para construir la marca que engloba todo el trabajo gráfico que se sustenta a continuación.

Desde los inicios del proyecto tuve el respaldo de mis padres, quienes a pesar de las diversas dificultades que se me presentaron en el camino, no dejaron de brindarme su apoyo y sus oportunos consejos, con los cuales no solo pude superar adversidades, sino también permitirme la apertura de un espíritu perseverante. Ello ha sido sustancial en favor de la visión trazada. A ellos, mi más profunda gratitud.

A mi primo y socio, Carlos Villanueva, con quien emprendí esta aventura empresarial. Gracias por haber confiado -y confiar al día de hoy- en mis aptitudes profesionales en el campo del arte y del diseño.

A mi asesor de tesis, Mg. Rafael Vivanco, quien habiendo seguido de cerca el desarrollo de la marca desde hace ya varios años, no dudó en ofrecerme su valiosa ayuda para el desarrollo del presente trabajo. 
LA RECREACIÓN ICONOGRÁFICA DE LAS CULTURAS ANCESTRALES PERUANAS COMO PROPUESTA VISUAL PARA EL FORTALECIMIENTO DEL IMAGINARIO EN LOS JÓVENES DE 20 A 30 AÑOS DE EDAD 


\section{INDICE}

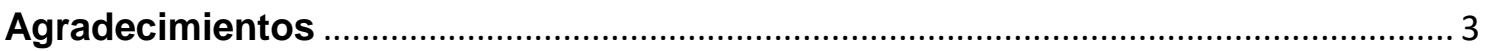

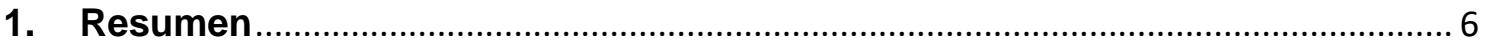

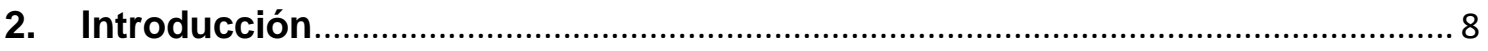

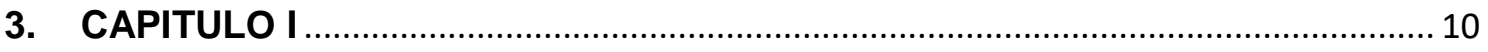

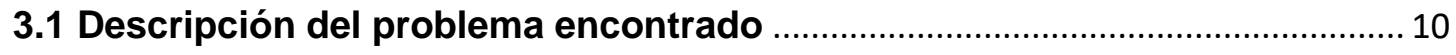

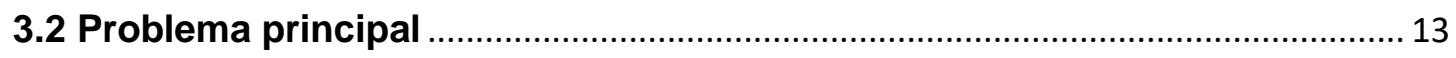

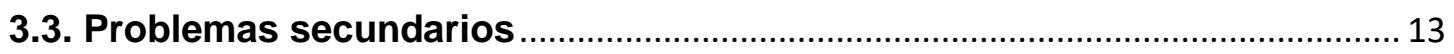

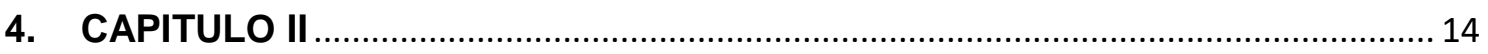

4.1 Justificación de la investigación ......................................................................... 14

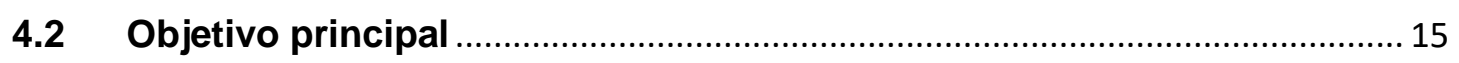

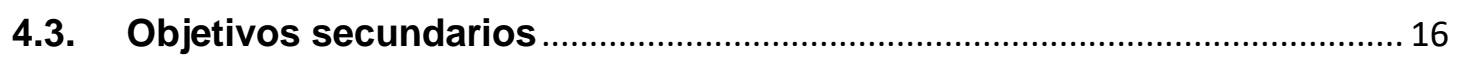

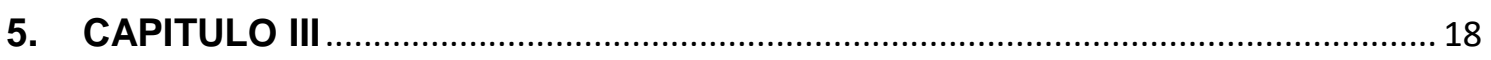

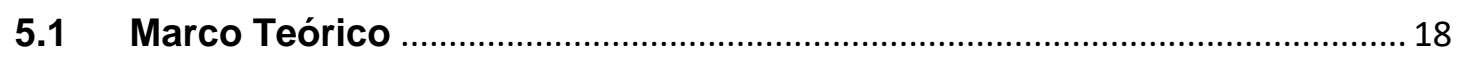

5.1.1 Cultura: algunas aproximaciones en su definición ................................... 18

5.1.2 Cultura visual, el reconocimiento de la imagen ...................................... 21

5.1.3 La iconografía, la ciencia de la imagen ................................................... 22

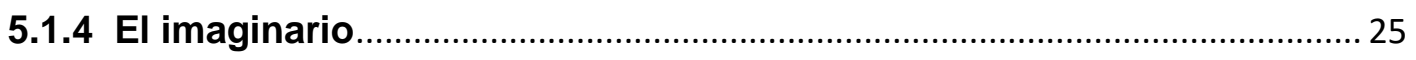

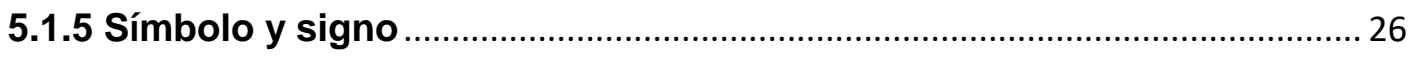

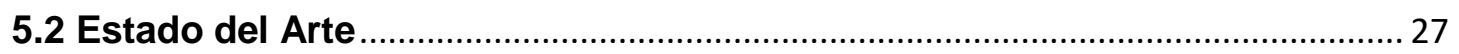

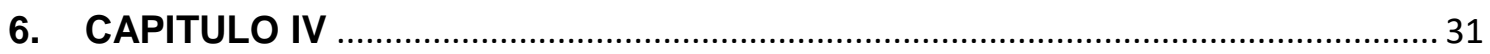

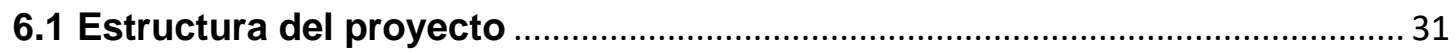

6.1.1 Concepto del proyecto: análisis conceptual y viabilidad........................... 31

6.1.2 Creación de la marca comercial .................................................................. 32

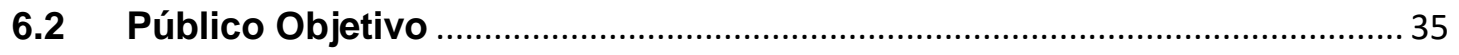

6.2.1 Actores involucrados en el problema ......................................................... 35

6.2.2 Fundamentación del público objetivo elegido ...................................... 40

6.2.3 Perfil del Publico objetivo …………………………………………….... 40

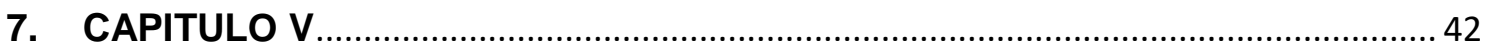

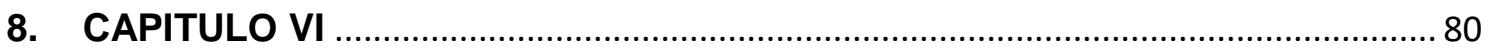

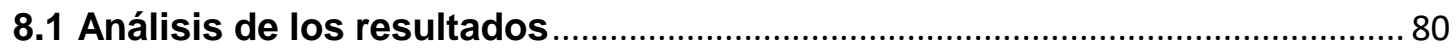

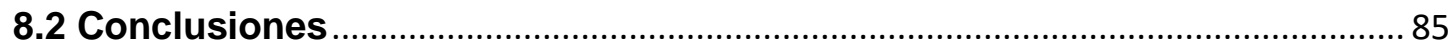

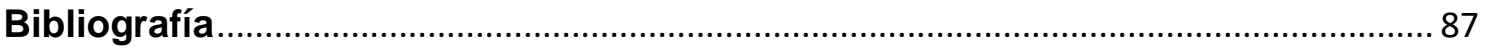




\section{Resumen}

Aún con la vasta riqueza cultural que el Perú posee, existen deficiencias educacionales y comunicativas que han permitido un debilitamiento de la cultura visual como configuradores del imaginario peruano, trayendo, en consecuencia, la inaccesibilidad y/o el desinterés hacia manifestaciones del patrimonio, ya sean materiales o inmateriales, que de una u otra manera, deberían estar orientadas a la construcción y al fortalecimiento de una identidad como Nación.

Dado que la cultura demanda de distintos modos y medios de comunicación para que éste pueda revitalizarse, recrearse, reinterpretarse y difundirse, la presente investigación da pie a un proyecto que, amparado en el arte y el diseño, propone nuevas retóricas visuales a fin de abordar el problema planteado. Las nuevas narrativas y las nuevas significaciones que puedan permitir vínculos simbólicos, cognitivos y relaciones de afecto y/o apropiación entre los intereses de un público joven y los objetos culturales que -debido a diversas razones- han permanecido ocultos e inadvertidos, son los principales objetivos del presente proyecto.

Palabras clave: Cultura visual, iconografía, patrimonio, imaginario, Perú, arte, diseño. 


\section{Abstract}

Even with the extensive cultural wealth that Peru has, there are educational and communicational deficiencies that have allowed a weakening of the visual culture as configurators of the Peruvian imaginary, bringing, consequently, the inaccessibility and / or the disinterest towards manifestations of the patrimony that of a or otherwise, they should be oriented towards the construction and strengthening of an identity as a Nation.

Given that culture demands different ways and means of communication so that it can be revitalized, recreated, reinterpreted and disseminated, this research gives rise to a project that, based on art and design, proposes new visual rhetoric in order to address the problem raised. New narratives and new meanings that can allow symbolic, cognitive links and relationships of affection and / or appropriation between the interests of a young audience and cultural objects that -for various reasons- have remained hidden and unnoticed, are the main objectives of the present project.

Keywords: Visual culture, iconography, heritage, imaginary, Peru, art, design 


\section{Introducción}

Con la llegada del Bicentenario, el Perú no solo predispone sus ánimos hacia un indudable escenario festivo, sino que también queda susceptible a la apertura de espacios de reflexión relacionados a la significación del evento. ¿Cómo nos vemos como país? Como nos relacionamos con su patrimonio y en qué medida influye en nuestra identidad? ¿Qué deseamos construir a futuro? 200 años como Nación libre e independiente nos induce a una atención que, evidentemente, no parte desde 1821, sino que se remonta a un pasado ancestral que se constituye como un aliciente de suma importancia con fines de consolidar nuestra imagen en el presente, y con ello, esbozar proyecciones hacia un futuro alentador.

Es en función a dicho legado, que la cultura inherente a la Nación se erige como uno de los pilares fundacionales de la imagen del país, los mismos que han hecho posible el discurso y la proyección comunicacional de diversas iniciativas, no solo a nivel individual sino también en ámbitos colectivos, como bien lo demuestran instituciones como PromPerú o la Marca Perú.

Ante las carencias educativas que vive el Perú en la actualidad, el desconocimiento de la iconografía relacionada al legado cultural peruano emerge como una de las tantas dificultades que el sistema educativo debe prestar atención, ya que ello conduce, inevitablemente, al desinterés y al debilitamiento de la cultura visual como configuradora de imaginarios visuales en la juventud. Ante dicha problemática, es de relevancia romper las barreras que impiden el acceso a la cultura y redireccionar los intereses visuales en los jóvenes, los mismos que, muy probablemente, encuentran familiarización con íconos de la cultura pop o de la cultura de masas insertas dentro del mainstream, pero que, en contraposición, perciben ajena la herencia cultural visual peruana que, por lo menos, debería ser reconocible a un nivel iconográfico por circunscribirse en los dominios de aquello que llamamos "cultura general".

El arte y el diseño han servido como medios de transmisión de ideas, emociones y modos de entender el mundo a través de las distintas etapas 
históricas que han contemplado el desarrollo del pensamiento humano, valiéndose de distintas funciones para tal fin: mágico-religiosa, narrativa, política, decorativa, pedagógica, memoria colectiva, etc. De la misma forma como lo hace el lenguaje, ambas disciplinas tienen la capacidad de construir realidades y como derivación de ello, de inducir -como agentes de cambiohacia la mejora de la calidad de vida de individuos y colectividades.

Frente a este escenario, las funciones de pedagogía y de memoria colectiva del arte y del diseño adquieren un matiz de relevancia. Si bien es cierto que el arte, a diferencia del diseño, ha desarrollado enfoques críticos, teóricos y hasta filosóficos con los cuales le ha permitido al artista una progresiva liberación con respecto a sus referentes para atender a la expresión de sus inquietudes más íntimas y profundas, el diseño adquiere más bien un patrón utilitarista o de practicidad que se ciñe a la solución de problemas específicos.

En ese sentido, la presente investigación expone la visualización de una problemática que de manera directa o indirecta afecta a la construcción de una realidad relacionada a los valores inherentes de la Nación. Con la finalidad de proponer soluciones visuales amparadas en la conjunción de arte y diseño, es que se plantea el presente proyecto. 


\section{CAPITULO I}

\subsection{Descripción del problema encontrado}

La educación, como derecho fundamental del ser humano ${ }^{1}$, tiene el papel de forjar y acuñar en los individuos todos los conocimientos y competencias necesarios con los cuales puedan acreditar la capacidad de enfrentar los retos de una sociedad cada vez más competitiva. En tal sentido, la educación no solo se constituye como un medio vital para el desarrollo social y económico, sino que resulta también sustancial para la facilitación de vías de acceso a la promoción y a la puesta en valor de todas aquellas manifestaciones culturales provenientes desde nuestro pasado ancestral hasta nuestros días, la cual ha provisto al país de una rica pluralidad cultural. Pese a que las políticas públicas educativas han conseguido, en buena forma, una educación inclusiva logrando altas tasas de escolaridad, el Perú manifiesta un problema de calidad de la enseñanza.

En la evaluación internacional dada por el Programa Internacional de Evaluación de Estudiantes (PISA). El puntaje peruano fue el menor de América Latina (alrededor de $20 \%$ por debajo del promedio de Chile, Argentina, Brasil y México), y muy inferior al de otros países de ingreso medio con un creciente logro educativo —como Tailandia-, con los cuales el Perú tendrá que competir. Únicamente alrededor de $5 \%$ de los estudiantes peruanos se desempeñan al nivel del promedio de los países de la Organización para la Cooperación y el Desarrollo Económico (OCDE). Ante dicho escenario se percibe un problema estructural, del que es de esperar que los accesos a los marcos cognitivos de la cultura, desde la escolaridad, se vean debilitados y consecuentemente, poco auspiciosos.

\footnotetext{
${ }^{1}$ La Declaración Universal de los Derechos del Hombre, adoptada por las Naciones Unidas, asevera en el artículo 26, inciso 1: "Toda persona tiene derecho a la educación. La educación tiene que ser gratuita, al menos en lo referente a la enseñanza elemental y fundamental. La enseñanza elemental es obligatoria. La enseñanza técnica y profesional debe ser generalizada; el acceso a los estudios superiores tiene que estar abierto a todos en plena igualdad de condiciones, en función del mérito".
} 
Frente a este problema que atañe a la institucionalidad educativa, es necesario tener en cuenta que también la institucionalidad concerniente a la cultura es responsable de los procesos de desarrollo y de las oportunidades relacionadas a las industrias creativas, culturales y turísticas como promotoras no solo de la generación de accesos a la empleabilidad, sino también de la creación de valor.

El Ministerio de cultura presenta también algunas dificultades, según se informa en los Indicadores UNESCO de la Cultura para el Desarrollo planteados a fines del año 2014, que dan cuenta de lo siguiente:

“(..) el país está a medio camino, es decir, tiene aún en agenda el fortalecimiento institucional cultural. Nos muestra también que se han registrado algunos esfuerzos de las autoridades nacionales para establecer políticas y mecanismos de promoción del sector y cumplir con las obligaciones y prioridades que se encuentran en las legislaciones nacionales". (UNESCO)

El informe también da cuenta de un necesario fortalecimiento de las acciones culturales debido a la limitada comprensión de los ciudadanos en cuanto a la implementación de las políticas públicas en cultura y los beneficios que estas podrían brindar a una colectividad:

"El Estado peruano tiene un Ministerio de Cultura desde el año 2010, desde entonces él o la responsable de la cartera ministerial tiene voz y voto en el Consejo de Ministros de Estado. En el Congreso de la República, existe una Comisión de Cultura y Patrimonio, en la cual se discuten los proyectos de ley del sector. Y a nivel de cada región -son 24 en el país, más la Provincia Constitucional del Callao- se cuenta con una Dirección Desconcentrada de Cultura, que depende del Ministerio de Cultura. Lo que está pendiente de fortalecer es la acción cultural municipal (a nivel provincial y distrital) y de los gobiernos regionales. Solo algunos de ellos deciden realizar proyectos o programas culturales y muy pocos son los que han establecido consejerías para la cultura o elevado a nivel de gerencia la administración municipal cultural. Esta situación podría deberse a la poca comprensión del ciudadano de lo que significa una política pública en 
cultura y de los beneficios que ésta podría traerle. Siendo así, no hay una ciudadanía alerta sobre sus derechos culturales". (UNESCO)

La problemática que se presenta en dominios educativos y culturales a nivel institucional es estructural, y se manifiesta como una antesala a lo que hace presuponer la presencia de deficiencias en cuanto a alfabetización visual y cultural, es decir, la desconexión y el desconocimiento de nuestro legado iconográfico se mostrarían como una problemática real. Frente a ello, emerge la siguiente pregunta: ¿Cuánto conocen los jóvenes acerca del imaginario peruano relacionado a nuestras culturas ancestrales?

Para responder a dicha pregunta, se efectuó un trabajo de campo consistente en el llenado de una encuesta de reconocimiento de 18 imágenes en las que, además de las imágenes propias de la cultura peruana, se incluían de otras culturas, además de personajes de películas y de videojuegos. Los personajes a identificar fueron los siguientes: Aia Paec, Pegaso, Naylamp, Thor, Kratos, Señor de Sipán, Amaru, Wiracocha, Darth Vader, Inti, Kon, Medusa, Centauro, Anubis, Supay, Señora de Cao, Dios Jaguar de la Estela de Raimondi y Raiden (Anexo 1). La encuesta fue dirigida a jóvenes de entre 20 y 30 años.

Los resultados fueron reveladores: de 100 entrevistados, solo el $10 \%$ pudo identificar a la principal deidad de la cultura Mochica, el dios Aia Paec; sin embargo, casi el 100\% reconoció a Raiden, el dios del rayo del videojuego Mortal Kombat. Solo el 25\% pudo identificar a Naylamp, el mítico fundador de la cultura Sicán, sin embargo un elevado $80 \%$ fue capaz de reconocer al dios de los muertos de la cultura egipcia, Anubis. De igual forma, casi el $100 \%$ pudo distinguir a la deidad escandinava Thor, personaje reformulado por Marvel; $y$ un porcentaje similar se dio en el reconocimiento de personajes propios de la mitología griega, tales como Pegaso o Medusa.

Con estos indicativos, se puede deducir que la globalización, la cultura popular $y$ el mainstream, sumado al aislamiento de las manifestaciones culturales autóctonas, impulsan el fenómeno de la aculturización. 


\subsection{Problema principal}

Se ha identificado el siguiente problema:

El debilitamiento de la cultura visual como configurador del imaginario peruano, ocasionando el desconocimiento del legado iconográfico en los jóvenes de 20 a 30 años de edad en el Perú.

\subsection{Problemas secundarios}

- Distanciamiento con las expresiones materiales e inmateriales constituyentes del patrimonio cultural del país, debido al debilitamiento de la cultura visual como configurador del imaginario peruano.

- Aparición de un escenario de indiferencia hacia todas aquellas expresiones que han conservado el legado patrimonial de las culturas ancestrales, transmitiéndolo generacionalmente hasta nuestros días. "Lo que no se comunica, no existe": los escenarios de insensibilidad o desinterés hacia las culturas vivas son probables como consecuencia del debilitamiento de la cultura visual como configurador del imaginario peruano.

- Progresivo desgaste de los componentes culturales que estructuran y construyen el concepto de identidad nacional. A falta de comunicación, arriba el desconocimiento; y con ello, la desavenencia del sentimiento de pertenencia hacia una colectividad histórico-cultural en el individuo. Lo que no se conoce, no se valora: los vínculos de identificación entre el ciudadano con su nación se desvanecerían como producto del debilitamiento de la cultura visual como configurador del imaginario peruano. 


\section{CAPITULO II}

\subsection{Justificación de la investigación}

El Perú es el resultado de la convergencia de las expresiones propias de pueblos originarios y culturas formadas que han habitado el territorio nacional a lo largo de la historia, la misma que data desde 3,000 años a. C con el surgimiento de la civilización más antigua de América (Caral) hasta la magnificencia del Tahuantinsuyo como el mayor imperio de la América precolombina. La valía que se desprende de un pasado que ha permitido la construcción de un patrimonio de lecturas polisémicas y su trascendencia en el tiempo hasta nuestros días con las expresiones de las culturas vivas, es uno de los alicientes a considerar para la justificación de la presente investigación. En esa dirección, Basadre asevera lo siguiente:

"Sólo aquello que tiene un futuro posee un pasado fecundo. Por eso para la Patria, que es totalidad en el espacio y continuidad en el tiempo, comunidad de destino y convivencia en el presente; el ayer vale si sus vibraciones repercuten aquí y se prolonga más allá... He aprendido que el Perú marcha dentro de una realidad multiétnica y una gran pluralidad de características y dentro de una trayectoria..." 2

Cabe resaltar que al hacer mención de la realidad multiétnica y la pluralidad inherente del Perú, Basadre también está insinuando que existe una naturaleza multicultural. Todas aquellas relaciones o nexos cognitivos con los que conviven los pueblos en un mismo espacio geográfico compartiendo o evitando características sociales, religiosas, culturales o de género han posibilitado la

\footnotetext{
2 J. BASADRE: La multitud. la ciudad y el campo en la historia del Perú. Lima 1980.
} 
emergencia de dicha multiculturalidad. Según menciona Amorós, el rescate de las expresiones provenientes en el fenómeno de la multiculturalidad debería ser entendido como riqueza a fines de contribuir con el desarrollo del país:

Una de las principales riquezas que encontramos en nuestro país es la existencia de muchas lenguas y culturas, las cuales se encuentran aún vigentes en su medio natal por lo cual todavía son capaces de contribuir al desarrollo del país con cada uno de sus aportes (Amorós, 2002, p. 17)

Tomando en consideración la rica herencia ancestral del país, y haciendo hincapié en la difusión de las manifestaciones extraídas desde la multiculturalidad como estímulos inequívocos del desarrollo del país en el corto, mediano y largo plazo, se propone una investigación en función a las tres instancias temporales (pasado, presente y futuro) a fin de hallar soluciones usando al arte y al diseño como agentes de cambio.

\subsection{Objetivo principal}

Comprometerse con el fortalecimiento de la institucionalidad cultural significa no solo tener una predisposición para el rescate, el reconocimiento, la valoración y la difusión de todas aquellas manifestaciones que han conformado, a través del tiempo, el patrimonio material e inmaterial del país, sino que su fin intrínseco permite el acceso a oportunidades orientadas al desarrollo, tanto individual como colectivo. En dicha dirección, el papel de la cultura en relación al desarrollo y a la gesta de oportunidades es ratificado por la UNESCO al señalar lo siguiente:

"En el Perú es necesario establecer una agenda pública orientada a la generación de información clave sobre el rol de la cultura en los procesos de desarrollo. Esto permitiría reconocer en la cultura una gran oportunidad para el país, contribuyendo a impulsar lineamientos, estrategias, políticas, programas y proyectos a nivel nacional. Por ahora, el resultado de la aplicación de los IUCD está ayudando a 
reconocer el papel de la cultura y la urgencia de incluirla en los diversos planes nacionales de desarrollo" (UNESCO)

Al señalar el debilitamiento de la cultura visual como configurador del imaginario peruano, lo que deriva en el desconocimiento del legado iconográfico en los jóvenes de 20 a 30 años de edad en el Perú; el objetivo principal del proyecto está orientado a contribuir a la puesta en marcha de la visibilización de manifestaciones específicas del patrimonio que, debido a diversas razones, han permanecido ocultas o inadvertidas para cierto público objetivo. Haciendo uso de una recreación o reformulación visual que será sustentada en un capitulo posterior en el presente estudio, se busca construir una predisposición emocional en el espectador una vez que se ha establecido el vínculo visual con la imagen.

Con el fin de despertar el interés del observador hacia los soportes materiales que portan las imágenes transformándolos en objetos de deseo, se busca la generación de valor y con ello, el fortalecimiento de los sentidos de pertenencia y de identidad agenciados mediante la propuesta gráfica.

El objetivo sustancial está orientado hacia la ampliación de los marcos cognitivos de la cultura visual y el imaginario peruano en cierto público objetivo, a la par de la creación de nuevas narrativas junto a sus correspondientes resignificaciones.

\subsection{Objetivos secundarios}

- Dar a conocer el distanciamiento con las expresiones materiales e inmateriales constituyentes del patrimonio cultural del país, debido al debilitamiento de la cultura visual como configurador del imaginario peruano.

- Evidenciar la aparición de un escenario de indiferencia hacia todas aquellas expresiones que han conservado el legado patrimonial de 
las culturas ancestrales, transmitiéndolo generacionalmente hasta nuestros días. "Lo que no se comunica, no existe": los escenarios de insensibilidad o desinterés hacia las culturas vivas son probables como consecuencia del debilitamiento de la cultura visual como configurador del imaginario peruano.

- Visibilizar el desgaste de los componentes culturales que estructuran y construyen el concepto de identidad nacional. A falta de comunicación, arriba el desconocimiento; y con ello, la desavenencia del sentimiento de pertenencia hacia una colectividad históricocultural en el individuo. Lo que no se conoce, no se valora: los vínculos de identificación entre el ciudadano con su nación se desvanecerían como producto del debilitamiento de la cultura visual como configurador del imaginario peruano. 


\section{CAPITULO III}

\subsection{Marco Teórico}

Con la finalidad de cumplir los objetivos trazados, el proyecto requiere de un compendio de antecedentes y consideraciones hipotéticas con las cuales se pueda lograr una profundización teórica que soporte 0 sustente los lineamientos del proyecto, dentro de los cuales se manifiestan con relevancia, conceptos tales como la cultura, la cultura visual, la iconografía o el imaginario, los mismos que se tratan a continuación.

\subsubsection{Cultura: algunas aproximaciones en su definición}

La palabra cultura tiene sus raíces etimológicas en el latín cultus, que a su vez, proviene del vocablo colere, que significa cultivar. Es entre el siglo XIII y el siglo XVI que el término pasó de designar el cultivo de terrenos a referirse a acciones concretas o especializadas, en un sentido similar al que, en la actualidad, se nomina a actividades tales como la agricultura o la piscicultura $^{3}$. A mediados del siglo XVIII, con el arribo del Siglo de las Luces, el término se emparenta - de manera figurada- con una definición que lo aleja de sus previas concepciones materiales: entendida como el "cultivo del espíritu", consigue preponderancia en los ámbitos académicos inherentes a la época. Con el transcurrir del tiempo, se fue asociando no solo con la formación de la mente y de sus capacidades intelectuales, sino también con la idea de progreso y de civilización. La definición de la palabra cultura ha logrado una notable complejidad semántica en la medida que ha sido

${ }^{3}$ Cuche, Dennys, "La Noción de Cultura En Las Ciencias Sociales" 
abordada por el estudio de intelectuales y pensadores desde sus respectivas disciplinas, tales como la filosofía, la sociología, la antropología, la ciencia, etc. Dicho interés académico produjo una polisemia de la que se pudo compilar, en 1952, hasta 164 significados de la palabra cultura en Culture: $A$ Critical Review of Concepts and Definition, cuyos autores, Alfred Kroeber y Clyde Kluckhohn, propusieron a su vez, lo siguiente:

«La cultura consiste en formas de comportamiento, explícitas o implícitas, adquiridas y transmitidas mediante símbolos y constituye el patrimonio singularizador de los grupos humanos, incluida su plasmación en objetos; el núcleo esencial de la cultura son las ideas tradicionales (es decir, históricamente generadas y seleccionadas) y, especialmente, los valores vinculados a ellas; los sistemas de culturas pueden ser considerados, por una parte, como productos de la acción, y por otra, como elementos condicionantes de la acción futura.»

Las definiciones posteriores para la palabra en cuestión le permitieron ampliar sus aristas cognitivas. Un año después, en 1953, el antropólogo, filósofo y etnólogo francés Claude Lévi-Strauss, propuso una comprensión de la cultura en función a una mirada pluralista, anticipando la valoración de la diversidad como uno de los ejes de la posmodernidad filosófica que se manifestaría un par de décadas después:

«...un fragmento de la humanidad que, desde el punto de vista de la investigación de que se trate y de la escala en que esa investigación se lleva a cabo, presenta diferencias significativas con respecto al resto de la humanidad...» 4

A pesar de las posibles dificultades epistemológicas que se puedan presentar, existe una convergencia de conceptos usados en su definición, tales como sociedad, usos, costumbres, valores, creencias, artes, letras, ciencias, temporalidad, entre otros- con los que es posible aproximarnos a

\footnotetext{
${ }^{4}$ Lévi-Strauss, Claude , "Antropología estructural".
} 
un consenso en la contemporaneidad. Es así que mientras la Real Academia de la Lengua Española la define como "el conjunto de modos de vida y costumbres, conocimientos y grado de desarrollo artístico, científico, industrial, en una época, grupo social, etc", la UNESCO la describe de una manera más detallada, sin prescindir de las mencionadas concepciones:

«...la cultura puede considerarse actualmente como el conjunto de los rasgos distintivos, espirituales y materiales, intelectuales y afectivos que caracterizan a una sociedad o un grupo social. Ella engloba, además de las artes y las letras, los modos de vida, los derechos fundamentales al ser humano, los sistemas de valores, las tradiciones y las creencias y que la cultura da al hombre la capacidad de reflexionar sobre sí mismo. Es ella la que hace de nosotros seres específicamente humanos, racionales, críticos y éticamente comprometidos. A través de ella discernimos los valores y efectuamos opciones. A través de ella el hombre se expresa, toma conciencia de sí mismo, se reconoce como un proyecto inacabado, pone en cuestión sus propias realizaciones, busca incansablemente nuevas significaciones, y crea obras que lo trascienden.»

Entendiéndola desde las Ciencias de la Complejidad, la definición del término demandaría de enfoques inter y multidisciplinarios, participando disciplinas tales como: Antropología, Sociología, Semiótica, Historia del Arte o los Estudios Culturales. Desde este modelo paradigmático, se tiene una nueva comprensión de la cultura como un fenómeno emergente dentro de un particular sistema social. Si bien es cierto que una colectividad se estructura en función a individuos, ninguno de estos estaría dado a la cultura de manera aislada, sino que su surgimiento se debe a la interacción entre los individuos y las instituciones.

Así como el lenguaje construye realidades, el arte y el diseño hacen lo propio; y estos últimos ejercen también un valor preponderante en la construcción de lo que por cultura se ha tratado de definir sucintamente en 
los párrafos anteriores. Dado que la propuesta de soluciones a la problemática planteada en la presente investigación se circunscribe casi de manera exclusiva al ámbito visual, se procederá a delimitar los dominios de la palabra cultura hacia una intersección con lo que provee la sensibilidad propia de la vista. ¿Qué es la cultura visual?

\subsubsection{Cultura visual, el reconocimiento de la imagen}

El ser humano, con el devenir de la historia, ha sofisticado sus procesos cognitivos con fines de agudizar sus accesos y aproximaciones hacia un concepto que le ha resultado de sumo interés y valía: la verdad. Alineado a tal cometido, ya desde la filosofía clásica griega, conceptos como intuición, sensibilidad y/o razón se han visto envueltos en una intensa dialéctica a lo largo de la historia del pensamiento humano. El empirismo, en oposición al racionalismo cartesiano, fue la primera corriente filosófica que dio primacía a la experiencia sensible hacia la comprensión del mundo. A pesar de que ambas corrientes parecerían haber hallado un punto de posible comunión con el idealismo trascendental de Kant; en la contemporaneidad, los procesos cognitivos a partir de los sentidos han presentado serias dificultades con la presencia de los postulados de la Posmodernidad. Aun así, es inevitable asentir la relevancia de la sensibilidad fenoménica, la misma que le ha permitido al ser humano definir posturas particulares en sus modos de entender el mundo. Dentro de dicho marco cognitivo, el sentido de la vista es el que se ha visto largamente favorecido, y por consiguiente, ha influido sobremanera en el desarrollo y el devenir de la cultura. ¿De qué hablamos cuando nos referimos a cultura visual?

La cultura visual se ciñe a todas aquellas manifestaciones culturales afectas al sentido de la vista, tales como la pintura, la escultura, la arquitectura, la fotografía, el cine, el comic, el grafiti, la danza, el teatro, etc. No solo se refiere a la familiaridad o el reconocimiento de un conjunto de imágenes $u$ objetos específicos distintivos de una u otra cultura, sino también a factores interpretativos con los cuales acceder a una mejor comprensión de los mismos. Para acceder al nivel interpretativo se requiere, evidentemente, de 
una mínima cercanía o predisposición académica con la cual traer a colación los conocimientos provenientes de disciplinas tales como la semiótica, la sociología, la antropología, la historia del arte, los estudios culturales, etc.

Se tiene en cuenta, además, que la cultura visual, como agente de alfabetización visual, se hace preponderante en el mundo contemporáneo, donde las nuevas tecnologías han permitido el acceso a un flujo de imágenes nunca antes experimentado, reformulando de manera continua la relación entre el espectador y la imagen, permitiendo una vorágine polisémica. En esa dirección, Deleuze y Gauttari mencionan, en función a su propuesta ontológica como estructura y prefiguración rizomática, que el papel de la cultura visual "no cesaría de conectar eslabones semióticos, organizaciones de poder, circunstancias relacionadas con las artes, las ciencias, las luchas sociales".

Dentro de los ámbitos conceptuales de la cultura visual, una de las disciplinas que se encarga del estudio de las imágenes es la iconografía, desde la cual se han formulado distintas metodologías.

\subsubsection{La iconografía, la ciencia de la imagen}

La iconografía se constituye como un método descriptivo mediante el cual se decodifican los temas que se representan en imágenes u obras artísticas, abarcando el estudio de la simbología, la alegoría, los personajes, los atributos, y las relaciones entre éstos. La iconografía resulta siendo una ciencia fundamental cuando de descubrir los significados de la imagen o de la obra de arte se trata.

EI DRAE expone hasta 5 concepciones sustanciales:

1. f. Conjunto de imágenes, retratos o representaciones plásticas, especialmente e un mismo tema o con características comunes.

2. f. Representación o imagen de un personaje o de una realidad determinado.

3. f. Sistema de imágenes simbólicas.

4. f. Arte de la imagen o la representación plástica. 
5. f. Estudio de las imágenes o representaciones plásticas en el arte.

Teniendo en cuenta que el DRAE recoge la existencia de la palabra latina iconographia que procede de la griega єкovoүpapía (eikonographía), dichos términos no tenían el mismo sentido al que en la actualidad se usa la palabra iconografía, al menos, en ámbitos académicos; sin embargo, tenía una significación aproximada o parecida: descripción de imágenes, retratos, cuadros, estatuas o monumentos, y especialmente en función al arte del mundo antiguo. Según Castiñeiras (1998; 12), la iconografía consta de dos vocablos de origen griego: eikón (imagen) y graphein (descripción). La iconografía se trata, por lo tanto, de la descripción de imágenes.

El historiador de Arte Fritz Saxl -referente de preponderancia en la constitución del Instituto Warburg- se refiere a las imágenes dotándoles de un poder y un uso significativos en un lugar y tiempo específicos, ejerciendo un influjo de consideración en la sociedad que les cobija y trayendo consigo inevitables afecciones en el devenir y el desarrollo de la cultura. Sin embargo, son susceptibles a la fragilidad y pueden caer en desuso o en el olvido. Aun así, son capaces de reaparecer a pesar de siglos de ausencia. En dicho ínterin las imágenes pueden debilitarse, alterarse o trastocarse, manifestando procesos de adaptación o resistencia, derivando en posibles resignificaciones. En tal sentido, la iconografía ha propuesto, además, métodos para abordar la óptima comprensión de la imagen y de sus significados profundos, con los cuales se vincula con terrenos propios de la iconología.

Erwin Panofsky ubica a la iconografía dentro del desarrollo de la Historia del Arte y además, marcando diferencias con la formalidad: "es la rama de la Historia del Arte que se ocupa del asunto o significación de las obras de arte, en contraposición a su forma" ${ }^{5}$. El método propuesto por Panoksky para abordar el estudio de las imágenes consta de tres niveles, los cuales se explican de manera sucinta a continuación:

\footnotetext{
${ }^{5}$ Panofsky, Erwin, "El significado de las Artes Visuales".
} 
a. Nivel Pre iconográfico: se delimita únicamente a la instancia sensorial y a la descripción de atributos propios de la formalidad y la cromática.

b. Nivel Iconográfico: Instancia en la que se reconoce personajes, atributos, alegorías y simbolismos. Se requiere de una familiaridad 0 cierto grado de cultura visual para tal fin.

c. Nivel Iconológico: instancia en la que se demanda de una interpretación para llegar a los significados profundos de la imagen, para lo cual se requiere conocimientos específicos relacionados, tales como la biografía del autor o autores, sus influencias, sus pensamientos, el contexto, etc.

Con fines de ilustrar el método, se propone el siguiente ejercicio, a partir de la representación del personaje expuesto en la figura 1.

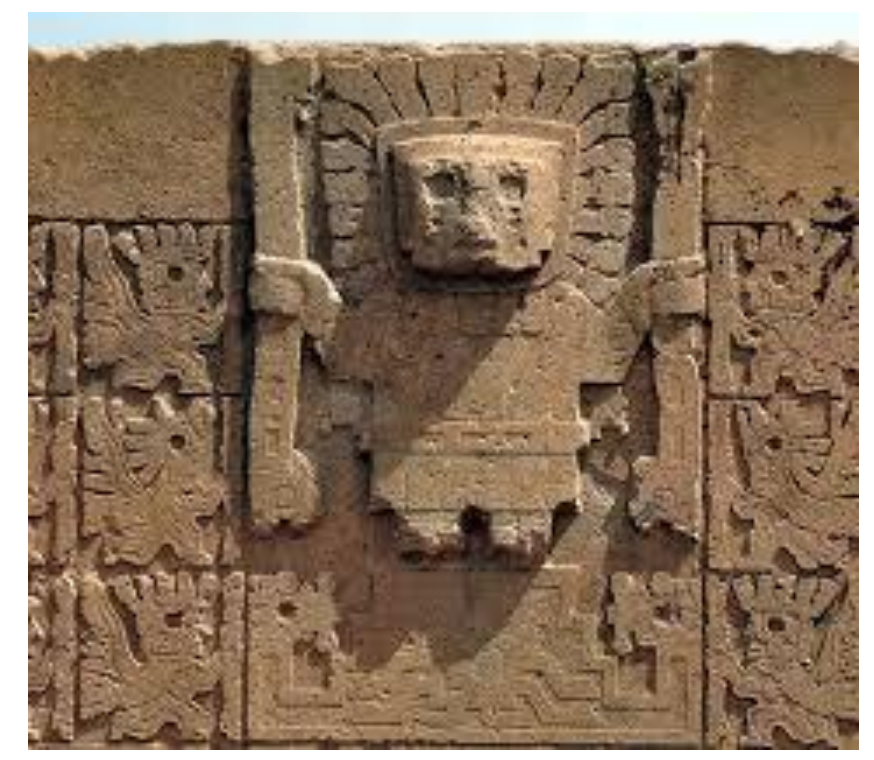

Fig. 1. Dios Wiracocha. Detalle de la Portada de Sol, Tiahuanaco, Bolivia.

a. Nivel Pre iconográfico: Se muestra a una figura de características antropomorfas que, exponiéndose en posición frontal, luce dos bastones o báculos (uno en cada mano). Está esculpido a alto relieve sobre una estructura lítica. Aparece de color grisáceo de manera uniforme. 
b. Nivel Iconográfico: Es la representación del dios Wiracocha, (también llamado el dios de los báculos o dios de las varas) esculpida en la estructura lítica conocida como Puerta del Sol, propia de la cultura Tiahuanaco.

c. Nivel Iconológico: Es la deidad más destacada dentro de la cosmovisión andina, cuya esencia como divinidad creador y hacedora del universo se mantuvo inalterable desde las culturas pre-incas (Se le ha relacionado con representaciones en Chavín en los tejidos Carhua en Paracas; en ceramios Nazca, en Pucará y en Tiahuanaco, prolongándose hasta dominios de los Wari) hasta el Tahuantinsuyo. Existen versiones míticas recogidas por cronistas que lo relacionan con el agua como elemento primordial y -debido a un tránsito posterior- con el fuego, como elemento solar; de la misma forma que lo vinculan a dos instancias o momentos de la creación: la oscuridad y la claridad. En la representación lítica del dios en la Puerta del Sol, se encuentran 48 figuras en bajo relieve representando seres alados y hombres arrodillados, además de la presencia de los llamados "trompeteros" debajo de los seres alados. Existen teorías que afirman que estos trompeteros marcan los movimientos solares, por lo que la puerta del sol sería un calendario solar.

\subsubsection{El imaginario}

Proveniente del latín imaginarius, la palabra imaginario hace referencia a todas aquellas proyecciones mentales que, independientes a los estímulos fenoménicos del exterior, se elucubran intrínsecamente en la imaginación.

Edgar Morín ${ }^{6}$ propone que los imaginarios se han construido como un recurso cultural usado por el Homo Sapiens, en el que pone en contraposición su mundo subjetivo (aquel construido como producto de su

\footnotetext{
${ }^{6}$ Edgar Morin, El paradigma perdido. Ensayo de bioantropología, Barcelona, Kairós, 2000, pp.113-173.
} 
evocar imaginativo) frente al mundo susceptible a la sensibilidad, es decir, al mundo fenoménico u objetivo. Dado que los cimientos antropológicos de la cultura se enmarcan en lo simbólico y lo imaginario, afirma Morín, que el Homo Sapiens es un Homo Demens. Es así que en el origen de la cultura, el Homo Sapiens estaría predispuesto a un componente de irracionalidad, no solo para formular sus particulares modos de entender el mundo, sino también para afrontar su destino, con lo cual daría pie a una proyección que impulsaría sus imaginarios.

Dado que los imaginarios son expresiones representacionales, éstos están sujetos al análisis de la realidad, y por tanto a ámbitos perceptivos y cognitivos.

Para Vitta, la representación es un elemento medidor entre el pensamiento y la realidad, lo que genera imaginarios:

"el imaginario puede entenderse como una especie de retícula a través de la cual contemplamos las cosas"..."conforma un agitado magma de expectativas, voluntades, miedos, aspiraciones, creencias y convicciones ampliamente compartidas que empujan la conciencia individual y colectiva- con una fuerza explosiva e inconsciente hasta sus límites, orientando en gran medida nuestro comportamiento"

\subsubsection{Símbolo y signo}

El símbolo es la representación sensorial de otra realidad, con la que expone una relación convencional socialmente aceptada. El símbolo es una sugerencia espiritual, por lo que su apariencia en el mundo sensible es secundaria; se asemeja a la abstracción propia de las ideas.

Por otro lado, el signo es un grafismo que contiene un valor semántico, por sí sólo o en unión de otros. Establece el nexo de unión entre el mundo conceptual y lingüístico y el mundo de la expresión gráfica a manera de convención. El estudio de los signos se lleva a cabo mediante la semiótica.

Hegel usa unos ejemplos para ilustrar la diferencia y la relación entre símbolo y signo: 
"En el mero signo la conexión mutua que existe entre el significado y su expresión es sólo un vínculo totalmente arbitrario...Otro ejemplo de estos signos son los colores, que se usan en las escarapelas 0 banderas (...), tales colores no contienen por lo demás en sí mismos ninguna cualidad que sea común con su significado, por ejemplo, la nación por ellos representada..."

"Muy distinto es el caso, en efecto, cuando un signo debe ser símbolo. El león, por ejemplo, es símbolo del coraje, el triángulo, de la trinidad. En consecuencia, estos tipos de símbolos tienen la presencia sensible, real ya en su propia existencia de ese significado, para cuya representación y expresión son usados...." ${ }^{7}$

\subsection{Estado del Arte}

A continuación se listan algunos proyectos gráficos que han hecho uso de elementos iconográficos destinados a configurar imaginarios apelando a conceptos, retoricas y categorías estéticas distintas. Los dos primeros se desarrollan en Perú, y el tercero, en Boivia.

\section{Cherman}

German Quino Ganoza, cuyo nombre artístico es Cherman, hace uso de la ironía, del sarcasmo, del sentido del humor y del espíritu crítico para retratar personajes icónicos de la historia y de la cultura popular del Perú. Para tal fin, recure a la ilustración vectorial.

Con claras influencias del Pop Art, su estilo grafico es el resultando del redibujo de las representaciones de los rostros de dichos personajes mediante la aplicación de trazos limpios, concisos y definidos bajo una cromática que usualmente se delimita a los colores negro, blanco y rojo. De la misma forma que, con frecuencia, se da licencia para la aplicación de distorsiones y

\footnotetext{
${ }^{7}$ Hegel, "Estética, Libro Tercero: La forma del arte simbólico".
} 
añadiduras de elementos fantásticos ajenas a los retratos, las frases relacionadas a éstos, que usualmente complementan al discurso gráfico, son también susceptibles a dicha distorsión. La retórica y el mensaje visual inducen al público objetivo a una autocrítica en función a nuestro rol como ciudadanos pertenecientes a una sociedad y hacia la construcción de una identidad y a un sentido de pertenencia a la misma. La figura 2 muestra un ejemplo de ello.

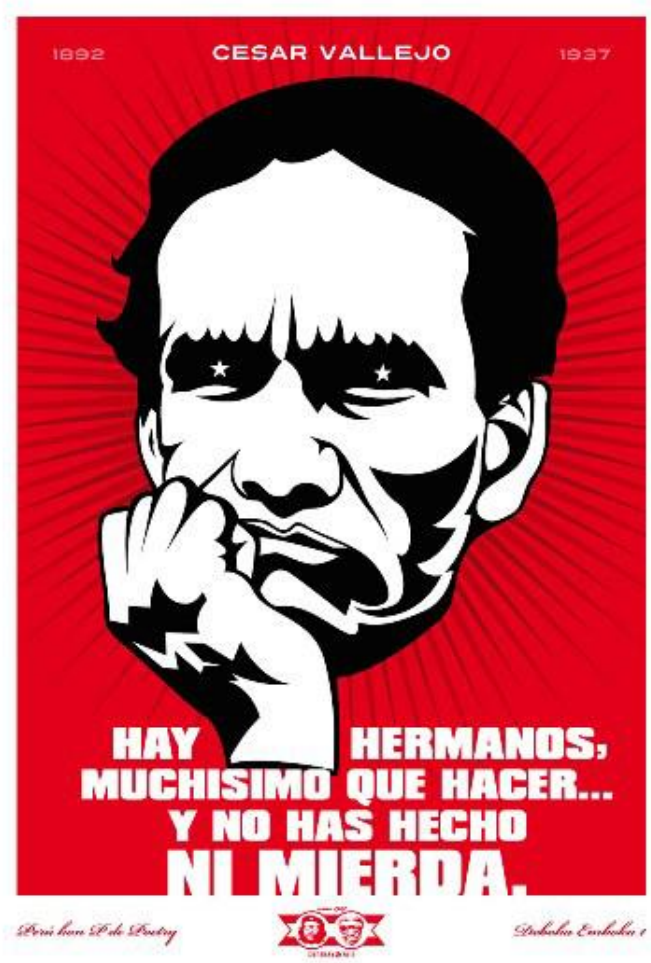

Fig.2. Cherman, César Vallejo, afiche

Se muestra la representación ilustrada del poeta Cesar Vallejo en función a una foto suya -quizás la más popular del poeta- en la que la propuesta gráfica propone no solo una reinterpretación de la expresividad en función a la inclusión de elementos fantásticos ornamentales (estrellas en las pupilas y el aura radiante detrás de la cabeza), sino que a la frase de Vallejo "hay hermanos muchísimo que hacer" se le aplica una extensión en la que apelando a la sátira y al lenguaje soez propio del habla popular- se manifiesta una evidente denuncia, criticando la inacción, la pereza, la negligencia o la indolencia del ciudadano peruano promedio: "y no has hecho ni mierda". 


\section{Cuy Arts}

Haciendo uso de ilustraciones vectoriales, el estilo gráfico de la marca Cuy Arts tiene una propuesta visual enmarcada en la categoría estética de lo cómico. En la vida cotidiana se advierte, a través de particulares gestos, expresiones, actitudes, posturas o manifestaciones materiales o inmateriales en individuos 0 colectividades, una relación inesperada, insospechada, contradictoria y/o espontanea de ideas que son capaces de generar el efecto de la risa en el espectador. En dicho contexto se manifiesta la comicidad, sin embargo, no es sino hasta que exista una voluntad creadora detrás de una obra con la finalidad de volcar dicho efecto que se puede apelar a la categoría estética de lo cómico, de lo contrario, solo se circunscribiría al marco de la cotidianidad.

Dicha categoría estética está presente en Cuy Arts y para tal fin, hace uso de temas relacionados a la cultura peruana, donde los principales exponentes son sus habitantes en su relación con las manifestaciones propias del contexto natural y cultural al que pertenece. La figura 3 expresa lo dicho: se aprecia la representación de un hombre andino y una llama sobre una balsa de totora, presumiblemente navegando sobre el lago Titicaca. La llama procede a comer, alegremente, el material del que está hecha la balsa -la totora-, mientras que el hombre la contempla con una pasividad disconforme al tiempo que brota un chorro de agua proveniente del agujero causado en el medio de la embarcación.

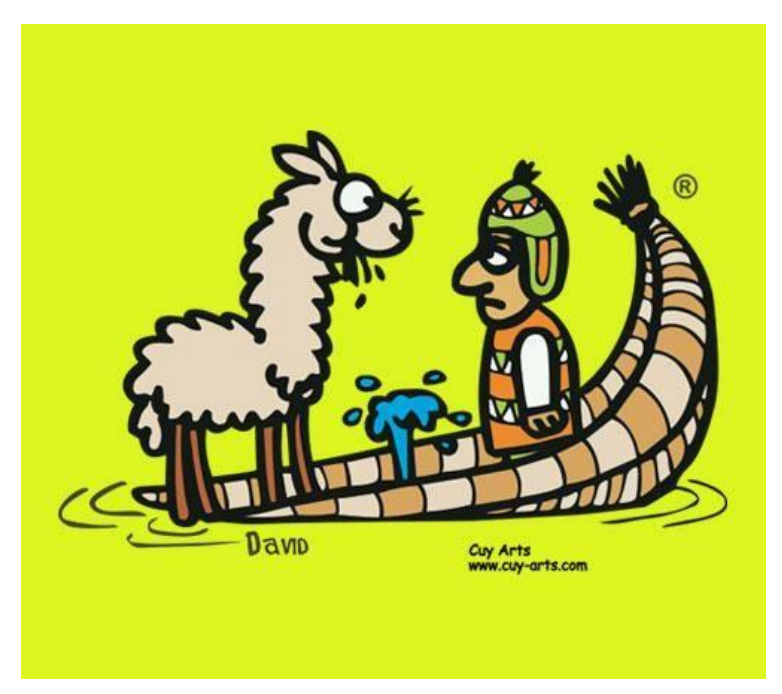

Fig.3. Cuy Arts, Totora hundiéndose, ilustración vectorial 


\section{Pumakatari}

A nivel internacional, se cita el proyecto Pumakatari, que es un sistema de buses de transporte de la ciudad de La Paz, Bolivia, cuyo primer nombre fue La Paz Bus. Pumakatari se concibe a partir del trabajo de identidad, imagen e información dirigido por Blanca Acosta, Hugo Aseff y Pablo Gallardo. Se recurrió a la ilustración digital para la representación de la iconografía de la cerámica ceremonial de la cultura Tiwanacota del periodo clásico para la construcción de la imagen de la red vial. En función a la reformulación de las expresiones visuales propias de dicha cultura, se construyó toda la imagen y la identidad de la marca. El proyecto abarcó también toda la señalética, además del diseño del interior y del exterior del bus junto a los mapas de las rutas implicadas. La figura 4 muestra el diseño visual del exterior del bus con la aplicación de la iconografía.

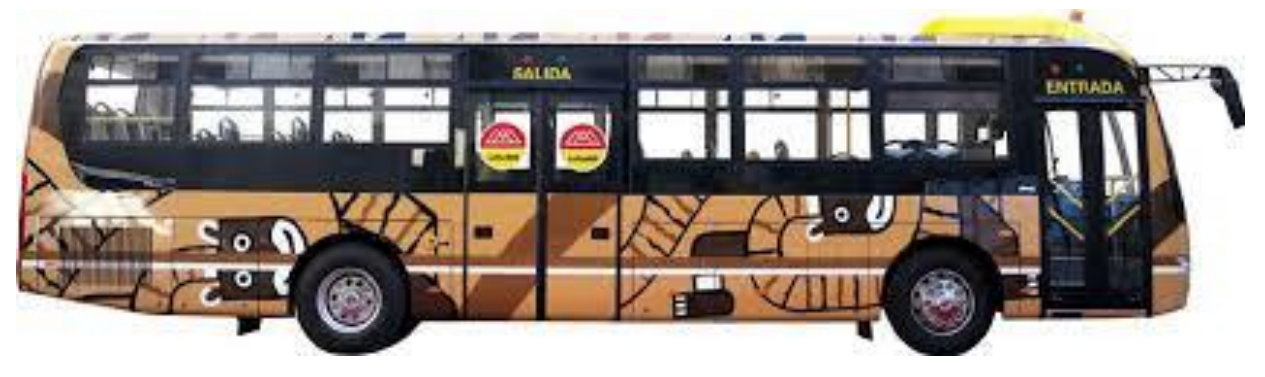

Fig. 4. Pumakatari, aplicación de diseño en bus 


\section{CAPITULO IV}

\subsection{Estructura del proyecto}

\subsubsection{Concepto del proyecto: análisis conceptual y viabilidad}

Dado que el presente proyecto apela, en esencia, a la preponderancia de la imagen, es necesario resaltar la relevancia que ésta ha adquirido en la presente era, donde la tecnología aplicada a los medios digitales ha cambiado incluso la formalidad, el contenido y la significación de la comunicación. Según Simone, R (2001), estos medios de comunicación han adentrado a la humanidad a una "Tercera Fase" -según adscribe- que permite la emergencia de nuevos procedimientos lógico-cognitivos en función de la universalidad de la imagen. Dentro del marco de las múltiples inteligencias $^{8}$, la inteligencia visual se ve favorecida a la posibilidad de un constante desarrollo en comparación al declive de la inteligencia lingüísticoverbal. En este sentido, la imagen se erige como un dispositivo de transmisión de información que se repotencia con las posibilidades inherentes a la era de la información, permitiendo, además, la ampliación de marcos epistemológicos.

El proyecto considera a la imagen como el medio idóneo para cumplir con los objetivos expuestos anteriormente. Se apuesta por la reinterpretación de la iconografía con la finalidad de despertar el interés del público objetivo, haciendo uso de herramientas propias del arte, del diseño gráfico, del diseño tipográfico y/o la ilustración. Con ello, se busca contribuir a la difusión y al fortalecimiento del imaginario visual de dichas culturas.

\footnotetext{
8 "Las múltiples inteligencias», fue una teoría expuesta por el psicólogo y neurólogo Howard Gardner. Esta propuesta rompe el paradigma tradicional de inteligencia como única y general, señalando su condición de pluralidad.
} 
Todas las ideas resultantes del quehacer previamente descrito producirán un registro de imágenes, narrativas y resignificaciones, las mismas que, ante la necesidad de la búsqueda de la generación de valor, requerirían de un concepto que uniformice y unifique el proyecto, para lo cual se decide por la creación de una marca comercial

\subsubsection{Creación de la marca comercial}

Con fines de crear una unidad bajo la cual se pueda sintetizar un conjunto de atributos, que pueden ser no solo perceptuales sino también conceptuales, que represente la esencia, el discurso y la personalidad del proyecto, se opta por la creación de una marca comercial. La marca, como compendio de una idea y la proyección de una imagen capaz de diferenciarse de sus competidores y de generar vínculos emotivos con sus consumidores, también predispone a estos últimos hacia una relación económica en función a los productos o servicios que la marca ofrece.

"Una marca es la sensación visceral que alguien siente hacia un producto, servicio o compañía" - Marty Neumeier

Habiendo establecido en los apartados posteriores la problemática, las dificultades y los objetivos del proyecto, la marca definirá sus lineamientos conceptuales en función a una premisa básica: el rescate de toda manifestación cultural propia del patrimonio cultural peruano que haya permanecido oculta, ignorada o inadvertida a la percepción del público objetivo a definir. Debido a dicha desconexión, el carácter de reserva o de discreción subyacente en dichas manifestaciones se establece como una noción de relevancia a partir de la cual se sustenta la argumentación conceptual y visual de la marca. Es así que partiendo de las definiciones acarreadas de la problemáticas dadas como sustento de la investigación (tales como cultura, cultura visual, iconografía, imaginario), se toma en consideración conceptos tales como lo enigmático, lo arcano, lo misterioso, lo místico o lo mágico, entre otros, a fin de aportar al proyecto matices que 
permitan definir el temperamento, carácter o el sentido de diferenciación inherente a la marca, el mismo que definirá, sustancialmente su imagen. Los conceptos relacionados a los objetivos del proyecto, tales como el fortalecimiento de los vínculos con el patrimonio, la identidad nacional y el espíritu reivindicativo, son considerados también como elementos esenciales a tomar en cuenta con fines de la construcción de los elementos de diseño destinados a la proyección de la imagen, tales como la definición del nombre de la marca, del logotipo, del slogan, y la posterior producción de recursos destinados a la comunicación.

\section{Nombre de Marca: Looch}

Teniendo en cuenta los objetivos de difusión cultural del proyecto, se considera un nombre que pueda sintetizar a la producción gráfica inherente al proyecto, que se conceptualice como un signo de identidad nacional, que apele a la naturaleza mestiza del país y que promueva una reivindicación frente a la problemática previamente descrita en el presente estudio.

A pesar de presentar una complejidad semántica, la palabra cholo engloba las ideas descritas. Siendo un término usado en países andinos y centroamericanos, su connotación encuentra diversos matices y significaciones según el contexto y la realidad social en cada uno de éstos. Si bien es cierto que en el Perú el término cholo se usó por un tiempo considerable con ánimos peyorativos, discriminatorios y/o racistas; actualmente se usa cada vez más frecuentemente como un signo de identidad nacional.

La personificación, la naturaleza mestiza, la identidad y los intereses reivindicativos del proyecto se consolidan entonces en la palabra Cholo. Sin embargo, la palabra en sí carece de la cuota de creatividad como para que se consolide como el nombre que llevará el proyecto. Es debido a ello que se opta por al uso de un anagrama a partir del término: Looch. 
A pesar las probables dificultades de pronunciación que se puedan presentar, tenemos un nombre que enmarca los conceptos descritos, apela al misterio, a lo arcano, a la intriga, a lo lúdico; es breve y de fácil recordación.

\section{Definición del slogan: "Cultura \& Contracultura"}

Si bien es cierto que el objetivo de la marca busca la conexión y promoción de todas aquellas manifestaciones visuales circunscritas en los ámbitos culturales, es necesario precisar que la producción gráfica basada en la alteración, el eclecticismo, o la reinterpretación de la iconografía, da pie a dificultades epistemológicas con las cuales se cuestionaría su pertenencia a lo que por cultura -en términos académicos- se conoce. En ese sentido, cabe preguntarse si la propuesta gráfica de la marca pertenece a instancias culturales 0 en todo caso, contraculturales. ¿Qué se entiende por contracultura?

Para entender los fenómenos contraculturales, es necesario asentir 0 reconocer la diversidad o la pluralidad del pensamiento humano en función a sus intereses particulares, ya sean sociales, políticos, religiosos, etc. Desde una mirada Hegeliana, la dialéctica, como forjadora y constructora de la historia, se ha manifestado también en ámbitos artísticos y culturales; es así que Los fenómenos de apropiación, resistencia, adaptación o sincretismo en el marco de la cultura han permitido la emergencia, casi de manera espontánea, de la contracultura, por lo que esta es tan antigua como la cultura misma. La contracultura no se opone necesariamente a la cultura, sino que, más bien, ejerce reacción en la manera en que esta se distribuye o imparte. Según Rentería, Carlos (2000), "La contracultura propone otra visión de la cultura».

La producción gráfica que le daría sentido la marca tomaría entonces información genuina de la cultura misma y en función a una predisposición poietica, sus propuestas iconográficas transitarían hasta los dominios de la 
contracultura. Es así que el slogan de la marca se sustenta desde un enfoque epistemológico y dialectico de ambos conceptos.

Más allá de las consideraciones conceptuales, el slogan es breve, de fácil recordación y posee contundencia fonética.

\subsection{Público Objetivo}

\subsubsection{Actores involucrados en el problema}

En este apartado se hace mención de los principales actores o entidades relacionados al proyecto. Para tal fin se consideran instituciones 0 grupos de personas cuyos intereses comunes se ven circunscritos en los dominios del arte, la educación, la cultura y la producción.

En lo que refiere a instituciones, se consideran las siguientes: UNESCO, Ministerio de Cultura, Ministerio de Educación, PromPerú, Marca Perú, y la Comisión Especial Multipartidaria Conmemorativa del Bicentenario de la Independencia del Perú.

En cuanto a las colectividades consideradas como actores, se considera, sustancialmente al grupo de jóvenes comprendido entre los 20 y 30 años.

A continuación se expone una breve descripción de cada uno de ellos, en función a los objetivos trazados en el presente estudio.

\section{UNESCO}

La UNESCO (Organización de las Naciones Unidas para la Educación, la Ciencia y la Cultura) es una entidad especializada creada el 16 de noviembre de 1945 por las Naciones Unidas, sin embargo, tiene sus orígenes tres años antes, cuando la restauración de los sistemas educativos era considerada un objetivo primordial para los países 
aliados en un escenario de post-guerra. En el marco de sus imperativos pacifistas, la UNESCO se orienta al desarrollo de las actividades culturales que estimulen la creación y la promoción y difusión del patrimonio, poniendo énfasis en apoyar la alfabetización. Dicha visión encuentra puntos en común con los intereses propuestos en el presente proyecto en función al desborde de la problemática relacionada al empobrecimiento del imaginario, lo que inevitablemente conduce no solo a una analfabetismo como tal, es decir, a la incapacidad de leer y escribir, sino también a un analfabetismo visual.

Es relevante rescatar que desde el enfoque epistemológico de la UNESCO, la cultura tiene un papel preponderante en el establecimiento de la paz y en el desarrollo sostenible de los pueblos:

"La UNESCO trata de establecer la paz mediante la cooperación internacional en materia de educación, ciencia y cultura. Los programas de la UNESCO contribuyen al logro de los objetivos de desarrollo sostenible definidos en el Programa 2030, aprobado por la Asamblea General de las Naciones Unidas en 2015". ${ }^{9}$

\section{Ministerio de Cultura}

El Ministerio de Cultura es responsable de todos los aspectos culturales del país. Sus campos de acción sobre los que ejerce sus competencias, funciones y atribuciones, son las siguientes, según información sustraída de su página web ${ }^{10}$ :

- Patrimonio cultural de la nación, material e inmaterial

- $\quad$ Creación cultural contemporánea y artes vivas

- Gestión cultural e industrias culturales

- Pluralidad étnica y cultural de la nación

\footnotetext{
${ }^{9}$ Definición de la UNESCO en su página web

${ }^{10} \mathrm{http}: / /$ www.cultura.gob.pe/es/informacioninstitucional/quienessomos
} 
Tomando en consideración los objetivos del proyecto, se destacan, entre las funciones principales del Ministerio de Cultura, la formulación, la ejecución y el establecimiento de estrategias de comunicación y promoción cultural; así como el fomento de todas aquellas expresiones artísticas que contribuyan al crecimiento y desarrollo del país en ámbitos culturales. Acorde a estos preceptos, se busca la constante construcción de una identidad cultural que, tal como se expuso el capítulo 2, está expuesta a un progresivo desgaste debido al debilitamiento de la cultura visual como configurador del imaginario peruano. Cabe subrayar que la visión del Ministerio de Cultura también considera -de la misma forma que lo hace la UNESCO- al desarrollo sostenible como el resultado de las políticas de integración y de fortalecimiento cultural: "Perú, país milenario que vive, reconoce, valora y construye su diversidad cultural, como base de su integración y desarrollo sostenible".

\section{Ministerio de Educación}

El Ministerio de Educación (MINEDU) es el sector del Poder Ejecutivo encargado de la educación en la nación.

Dada la relación entre educación, comunicación y cultura, según se ha citado previamente en el presente documento, es que se justifica la inclusión del MINEDU como un actor de relevancia, ya que sus objetivos hacen hincapié en el aprendizaje de calidad como impulsador del crecimiento o mejora de aspectos intelectuales o morales, es decir, como catalizador del progreso de las comunidades; de manera análoga a los vínculos de la cultura como gestor de oportunidades y propulsor del desarrollo. Acorde a ello, según la web de la institución, asevera lo siguiente:

"Nuestros objetivos son generar oportunidades y resultados educativos de igual calidad para todos; garantizar que estudiantes e instituciones educativas logren aprendizajes pertinentes y de calidad; lograr una educación superior de calidad como factor favorable para 
el desarrollo y la competitividad nacional, así como promover una sociedad que educa a sus ciudadanos y los compromete con su comunidad. En el ámbito docente fortalecemos capacidades para que los maestros ejerzan profesionalmente la docencia".

\section{PromPerú}

La Comisión de Promoción del Perú para la Exportación y el Turismo (PromPerú) es una entidad dependiente del Ministerio de Comercio Exterior y Turismo del Perú. Según la información extraída de su web institucional se encarga de formular, aprobar, ejecutar y evaluar las estrategias y planes de promoción de bienes y servicios exportables, así como de turismo interno y receptivo, promoviendo y difundiendo la imagen del Perú en materia turística y de exportaciones, de conformidad con las políticas, estrategias y objetivos sectoriales. Su misión busca la promoción de la imagen del país, sus destinos turísticos y sus productos de exportación con valor agregado, contribuyendo al desarrollo sostenible y descentralizado del país.

\section{La Marca Perú}

La Marca Perú, cuyo logotipo se muestra en la figura 5, es una estrategia de marketing que, alineada al concepto de Marca País, se encarga de construir un valor intangible en función a la reputación e imagen del Perú, rescatando los factores positivos de diversos ámbitos, ya sea: el turismo, la cultura, la biodiversidad, los deportes, las empresas, los organismos públicos, etc. 
Fig. 5. Logotipo de la Marca Perú

Según la definición dada en el marco institucional de la marca Perú, ésta es "una herramienta que busca impulsar el turismo y las exportaciones. Para atraer inversiones, transmite con eficacia la propuesta de valor de nuestro país". Dado el interés de creación de valor en la imagen del país, es que la propuesta del proyecto -según los objetivos previamente descritos- busca una contribución hacia tal fin. La promoción de una percepción favorable del país desde miradas extranjeras es una meta en común, por lo que incluso se haría necesario concretar la licencia de uso, acorde a la siguiente aseveración extraída de su web institucional: "ser licenciatario de la Marca Perú es unirse al esfuerzo para promover la imagen positiva de nuestro país a nivel nacional e internacional".

\section{Comisión Especial Multipartidaria Conmemorativa del Bicentenario de la Independencia del Perú}

El objetivo de la Comisión Especial Multipartidaria Conmemorativa del Bicentenario de la Independencia del Perú es afianzar la democracia y fortalecer los ideales de la construcción de la República del Perú en el contexto de la conmemoración del bicentenario de la independencia nacional.

Dentro de sus objetivos, se menciona a la promoción de la identificación, el diseño, la implementación, la restauración y la conservación del patrimonio cultural y arquitectónico. Dada la confinidad con las metas culturales del proyecto, es que la comisión se cita como uno de los actores a considerar dentro del proyecto.

A continuación se describe a los actores relacionados a colectividades 0 grupo de personas:

Público joven (20-30 años), NSE: C+, B

\section{Educadores / maestros}




\subsubsection{Fundamentación del público objetivo elegido}

El público objetivo, -o target- son las personas o las instituciones a las cuales irá dirigida la marca; es decir, son los grupos interesados en el producto que la marca ofrece, por lo que, según sus preferencias, son proclives a llegar a tratos comerciales en función a campañas de publicidad y marketing promovidas por la marca.

Entre los actores descritos en el apartado anterior, el producto artístico y grafico que promoverá el proyecto estará destinado a despertar el interés visual del segmento comprendido por la juventud comprendida en el rango de 20 a 30 años, entre ambos sexos, en el Perú.

\subsubsection{Perfil del Publico objetivo}

\section{Características sociodemográficas:}

-Sexo: Masculino y femenino

-Edad: Se considera a un público joven entre el rango de los 20-30 años

-Nivel de estudios: Secundaria, técnica, superior

-Estado civil: Soltero principalmente

-Ubicación: Todo el Perú

\section{Características socioeconómicas:}

-Nivel Socioeconómico (NSE): C+, B.

-Ingresos: entre el sueldo mínimo (S/.850) y S/.3,000

-Gastos:

\section{Características Psicográficas:}

- Personalidad: extrovertidos, expresivos, curiosos, comunicativos, creativos, inconformes. 
- Estilo de vida: Lleva una vida bohemia; toma diversiones los fines de semana, asiste a actividades y eventos culturales, tiene conciencia por el medio ambiente, le gusta participar de experiencias nuevas; hace activismo social, político y cultural.

- Sistema de valores: Identificación con el arte y la cultura, con un particular gusto por las expresiones llamadas contraculturales tales como el arte urbano, los grafitis, los tatuajes, los comics, etc.

- Tendencia política: inclinación hacia políticas de izquierdas: colectivismo / socialismo / inclusión social / pluralismo / progresismo / rechazo al status quo.

- Identificación con los valores culturales de la nación.

- Ambientalismo y ecologismo

- Cosmovisión: espiritualidad, panteísmo, New Age, chamanismo, cultos andinos, deísmo, ocultismo. 


\section{CAPITULO V}

\subsection{Análisis del Diseño}

El presente capitulo aborda todo lo concerniente al proyecto en cuanto a su expresión visual; es decir, ya habiendo identificado el concepto bajo el cual se tomará posición frente a la problemática y sus vías de solución en función a las características evaluadas en el público objetivo, se procede a la construcción de todos aquellos elementos visuales que formarán parte de la imagen corporativa de la marca.

\section{Diseño del logotipo}

La Fig.6 muestra el diseño del logotipo, cuyo sustento se expone a continuación:

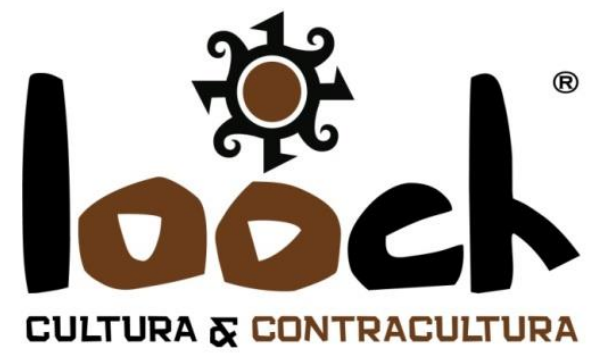

Fig.6. logotipo de la marca Looch

\section{Concepto}

Se hace uso de la representación de un Inti, la deidad más significativa dentro de la mitología inca. Se construye a partir de una combinación de formas angulosas y rectas. El sol actúa compositivamente con respecto a las verticales que se levantan de las letras "l" y "h" para dar la impresión de centralismo y de apertura frente al bastión que representan las letras. 


\section{Tipografía}

La tipografía no cuenta con formas geométricas definidas por el que se deja de lado el concepto de modernidad para apelar a lo rústico y/o el trabajo artesanal. Se transmite la idea de las estructuras líticas que predominaron en tiempos precolombinos e incaicos, tales como Sacsayhuamán o Machu Picchu.

\section{Cromática}

Color ocre rojo: Su utilización se debe a la gama de colores usada en la cerámica precolombina e incaica, donde predominaban los colores rojo, ocre, crema y negro. El rojo ocre seleccionado actúa sobre el centro de la representación del Inti y sobre las dos letras "o" aprovechando la similitud formal entre dichos elementos.

Color negro: Se hace uso del color neutro negro para reforzar las ideas de lo enigmático, lo arcano y/o el misticismo inherentes a la marca.

El anexo 2 muestra los valores en RGB y CMYK del logotipo en su versión original, así como en sus versiones en negativo. Además se muestra el área visible del mismo.

\section{Diseño de Papelería}

El diseño de identidad corporativa contempla el diseño de las siguientes piezas gráficas: hoja membretada, sobre A4, tarjetas personales y carpeta.

La figura 7 muestra el diseño de la tarjeta personal. La tira se desarrolla sobre un fondo con un degradado que va del beige hasta el marrón oscuro ubicándose el logotipo en su versión original en el extremo superior izquierdo. Los datos personales junto con los respectivos datos (cargo, teléfono móvil y fijo, dirección de correo y dirección de oficina) se colocan 
sobre el lado derecho de la tarjeta. De manera contrastada, la retira expone el logotipo en su versión negativa en dorado, de manera centrada sobre el fondo junto con la dirección web.
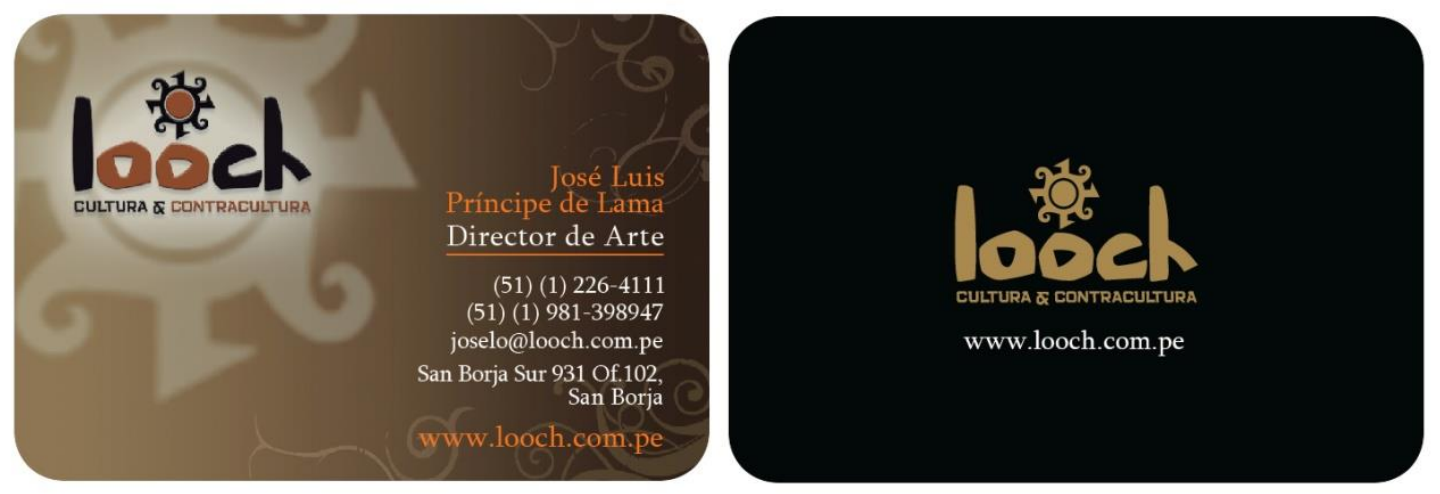

Fig. 7. Diseño de tarjetas personales de la marca Looch

\subsection{Diseño de la Comunicación}

En la presente sección se describirán los medios de comunicación para llegar al público objetivo, definiendo el discurso o estilo visual con los cuales se lograrán establecer los vínculos perceptivos a fin de lograr despertar el interés. Asimismo, se sustentarán las estrategias a emplear, mediante las cuales se logrará una perduración del mensaje con el tiempo. Se definirán también los medios a utilizar: impresos, digitales, audiovisuales, interactivos, etc, así como las etapas de comunicación del proyecto.

\section{Comunicación}

Siendo la imagen el bastión sustancial bajo el cual se erige el presente proyecto, se hace necesaria la definición de una retórica o un plan discursivo bajo los cuales se transmitirá la información visual. La UNESCO, en su Informe de Indicadores de Cultura para el Desarrollo establece una relación estrecha entre la cultura y la comunicación: 
"La comunicación es el intercambio de ideas, conocimientos, mensajes e información. La cultura y la comunicación están estrechamente interrelacionados. La cultura requiere diversas formas de comunicación para prosperar, crear, ser re-creada y compartida. Al mismo tiempo, la cultura da forma a una gran parte de los contenidos y las formas de comunicación. Juntos, la cultura y la comunicación tienen la capacidad de producir y difundir una gran riqueza de información, conocimientos, ideas y contenidos, contribuyendo a la expansión de las opciones de las personas en llevar la vida que valoren, creando así entornos propicios para el desarrollo centrado en las personas". (UNESCO)

Al hacer hincapié en las formas de comunicación para que la cultura pueda prosperar, crear y recrear, se hace énfasis en la naturaleza dinámica de la cultura, lo cual le permite, con el paso del tiempo, construir nuevas narrativas y con ello, la posibilidad de accesos a despliegues polisémicos. El proyecto tendrá entonces, como core business, la producción de ideas expresadas en un lenguaje visual que apela a la formulación de recreaciones iconográficas de ciertos objetos o temas culturales a fin de lograr una predisposición emotiva del público objetivo frente a una nueva estética y sus correspondientes resignificaciones.

\section{Técnicas artísticas y gráficas para la comunicación}

¿Cómo se va a transmitir dichas historias? Ante dicha interrogante, es necesario definir los recursos y técnicas gráficas que se harán necesarios para formular el cometido de la marca. El diseño, la ilustración, el estilo grafico y la serigrafía son los temas a tratar en este apartado.

\section{Diseño e ilustración}

La palabra diseño tiene sus orígenes en el término italiano disegno, el mismo que guarda sus raíces etimológicas en la palabra designio, que a su vez proviene del término signare, cuya significación alude a "lo que està por venir". Fue en el contexto del Renacimiento que el arquitecto, escultor, pintor y 
considerado uno de los primeros historiadores de Arte, Giorgio Vasari, acuña al disegno como una prefiguración o una cosa mentale desde la cual proviene la reflexión primigenia que sirve de base y que impulsa la realización de las ideas. En ese sentido, el disegno apela a la imaginación o a la inventiva propia del ingenio como dador de soluciones, El requerimiento intelectual para tal fin fue lo que Vasari destacó con el fin de elevar a la pintura, la escultura y la arquitectura al plano de artes liberales.

Es de relevancia subrayar que, el disegno, como antesala para el para que lo cual se demandaría de habilidades relacionadas al conocimiento de la anatomía, perspectiva matemática o la geometría, para lo cual las ideas se concretan haciendo uso del Dibujo. No en vano, Alberti plantea una relación entre el carácter de prefiguración o de antesala del disegno con la ejecución del dibujo: "Futuri operis delineario" (las líneas delinean el futuro).

Por otro lado, la palabra ilustración proviene del latin illustrare, que significa alumbrar, iluminar, purificar, exponer a la luz.

La voz ilustrar deriva del latìn illustrare, éste, de lustrare, (..) Su significado más extendido es el de "instruir", proporcionar cultura a alguien, conocimientos o información sobre cierta cosa (..) y también dar idea (una idea), descubrir, revelar; dar luz al entendimiento; difundir la ciencia o el saber, instruir, civilizar. ${ }^{11}$

En lo que respeta al acto de la ilustración como un recurso del arte y del diseño gráfico, se inicia con un concepto prefigurado -un disegno- en la mente del artista. La información que se revela o se expone hacia la experiencia sensible - en función al interés del artista de dar luz, clarificar o visibilizar los conceptos prefigurados- quedaría presta para la interpretación de los receptores enmarcada dentro del lenguaje visual, confirmando, de esta manera, la semántica primigenia del término illustrare.

\footnotetext{
11 Martínez Moro, J. La ilustración como categoría: una teoría unificada sobre arte y conocimiento. Ediciones Trea, Gijòn, pp. 57-58
} 
El proyecto hará uso de las herramientas propias tanto del diseño como de la ilustración. El diseño aplicado obedecerá se constituirá como un ejercicio intelectual adoptando la forma de una prefiguración conceptual dirigida hacia la solución de los problemas identificados. El diseño, de esta forma se agenciará como una propuesta de cambio. El recurso de la ilustración, por su parte, propondrá el lenguaje o el modo en que el arte se expresará con corrección y eficacia, a fin de "dar luz" a las ideas preconcebidas, deleitando, persuadiendo o conmoviendo al espectador.

\section{Estilo gráfico}

Al abordar cada tema, ya sea un personaje, una escenificación o una simbología, se permitirá una intervención creativa sobre éstos haciendo uso de diversos recurso gráficos con fines de lograr una composición que, además de lograr la reformulación visual, mantenga la prevalencia del concepto en su esencia original, según los fines de difusión que se establecen como objetivos del presente estudio.

Para tal fin, se hará uso de formas figurativas, tales como representaciones antropo, zoo y fitomorfas; así como las correspondientes a otras manifestaciones inanimadas de la naturaleza. El uso de abstracciones será también un componente sustancial en el trabajo gráfico, ya sean éstas expresadas como formas orgánicas, geométricas, o incluso asociadas a iconografías de culturas particulares. Se dará preponderancia al trabajo de los detalles.

La propuesta ilustrada de la marca, acorde a su discurso conceptual, apela a una retórica predispuesta a la evocación de conceptos relacionados al hieratismo, al misterio, a la expresividad, a la fuerza, a la mística, al dramatismo o a la magia, entre otros. Se pretende una aproximación a la categoría estética del sublime, marcando distancias con lo relacionado a lo bello, lo cómico o lo grotesco. Se evita también aproximaciones a lo kitsh, a lo camp o a lo naif. El discurso gráfico contempla, además, el uso de elementos tipográficos de distintas fuentes y familias acordes al discurso propuesto. 
Es sustancial el mencionar que, dado a que el proyecto usará la técnica de la serigrafía para plasmar los trabajos ilustrados en prendas de vestir principalmente, el estilo grafico quedará definido, en buena manera, a las limitaciones propias de la técnica.

\section{La serigrafía}

La serigrafía es un método de impresión en el que, haciendo uso de una malla tensada sobre un marco, (usualmente fabricado de madera o aluminio), se logra transferir tinta hacia otra superficie, permitiendo la impresión sobre esta última. La tinta sobre la malla solo logra traspasar sobre aquellas zonas donde no sido bloqueado su paso en áreas en las que se ha aplicado una emulsión o barniz. Cada malla deja el paso de un único color, por lo que es necesario tener consideraciones de cantidad de colores en función a los costos de producción. Este condicionamiento técnico definirá, de manera significativa, el estilo gráfico de las ilustraciones.

\section{Recreación y resignificación de imágenes culturales}

Habiendo definido los recursos conceptuales y técnicos para hacer uso de la recreación de elementos culturales como configuradores del imaginario, a continuación se analiza el proceso creativo a seguir a partir de un elemento simbólico de los pueblos indígenas de los Andes: la Chacana, la cual se expone en la figura 8

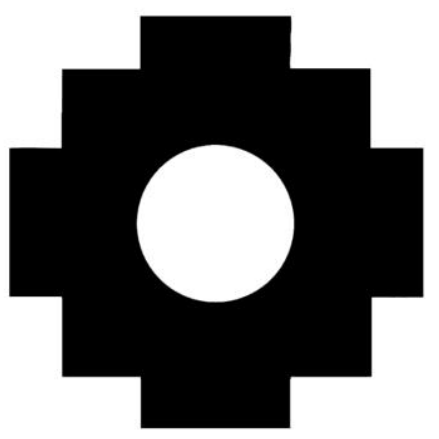

Fig.8. Representación de la Chacana 
1. En primera instancia se demanda la comprensión del tema a un nivel iconográfico, por lo que se recurre al método iconográfico de Panofsky

Nivel pre iconográfico: se muestra una figura geométrica de color negro sobre fondo blanco que, a manera de cruz, presenta simetría vertical y horizontal. Los extremos de la cruz se conectan con sus contiguos mediante una estructura escalonada. Un círculo de color blanco cala en el centro la composición.

Nivel iconográfico. Se trata de la Chacana, también conocida como cruz andina o cruz escalonada. Siendo un símbolo milenario de los pueblos andinos, el entendimiento y la interpretación que éstos tenían -y tienen aún- de su entorno natural y cultural, es decir, su cosmovisión, ha quedado representada en la Chacana.

Nivel iconológico: La Chacana es la representación de una idea que posee múltiples interpretaciones. El término Chacana proviene de las palabras quechuas chaka y hanan que significan "el puente a lo alto". Es bajo la idea de un vínculo escalonado hacia lo elevado que la Chacana sintetiza la comunicación de mundos simultáneos o paralelos entre los habitantes espirituales o fenoménicos que habitan en ellos. Dicho entendimiento, expresado en la simbología de la Chacana, es el que ha permitido al hombre del andino conservar su conexión y su inherente relación con el cosmos.

2. Siguiendo los lineamientos estéticos y conceptuales previamente descritos para la producción de imágenes, para la recreación del tema se formulan los siguientes propuestas:

- Dotar de dinamismo a la condición estática del símbolo dada por su inherente geometría. 
- Agudizar la sensación arcana del símbolo cubriendo su superficie con texturas envejecidas, dramatizando su antigüedad.

- Incluir elementos propios de la iconografía andina en favor de la estimulación del imaginario.

- Incluir elementos gráficos propios de la cultura popular, de la globalización y del mainstream, con el fin de generar conexiones visuales con el público objetivo.

La reformulación gráfica del tema queda expuesta en la figura 9 y la descripción de los elementos constitutivos de la misma se muestra en la figura 10. 


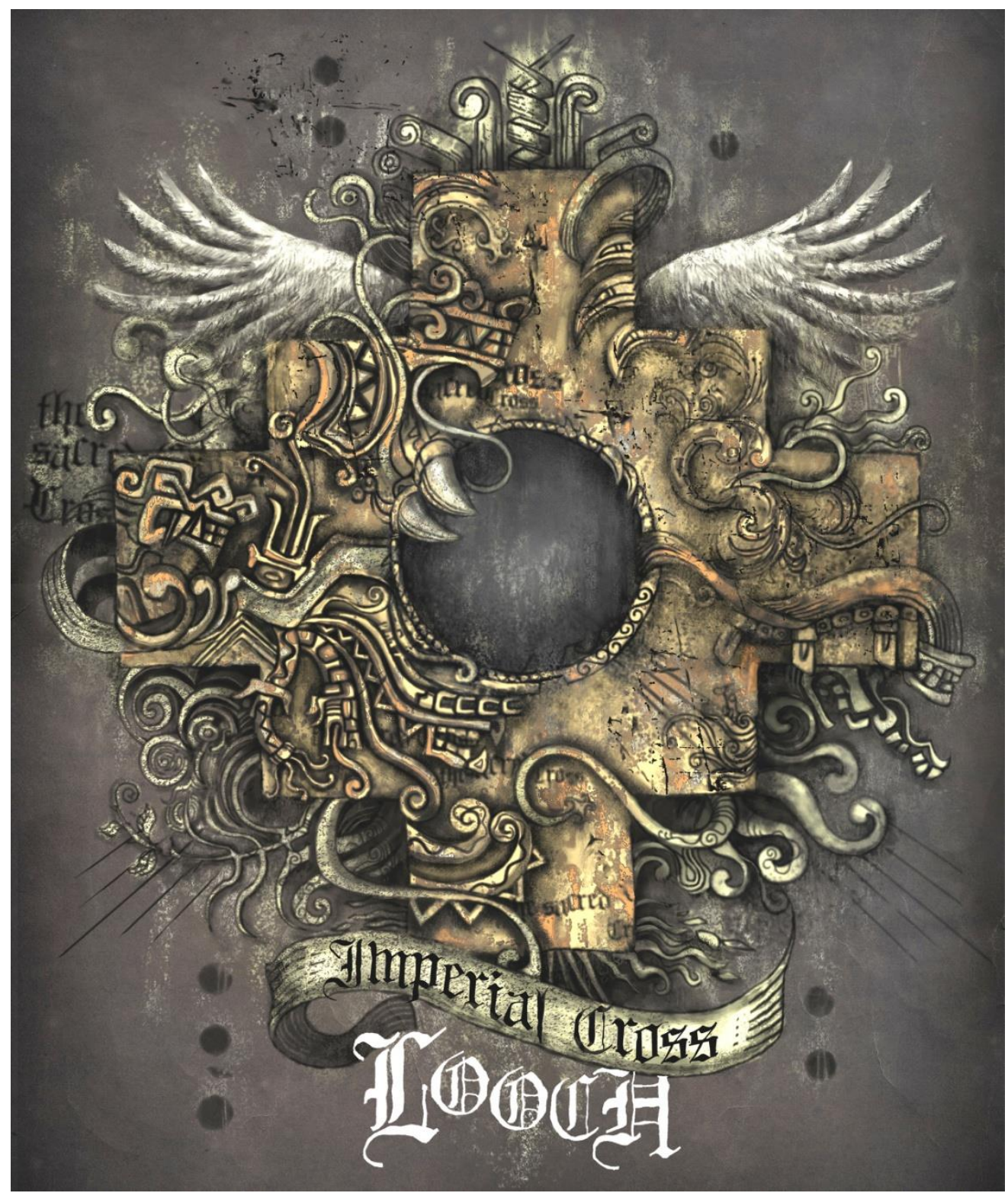

Fig. 9. Looch, Imperial Cross, ilustración digital 


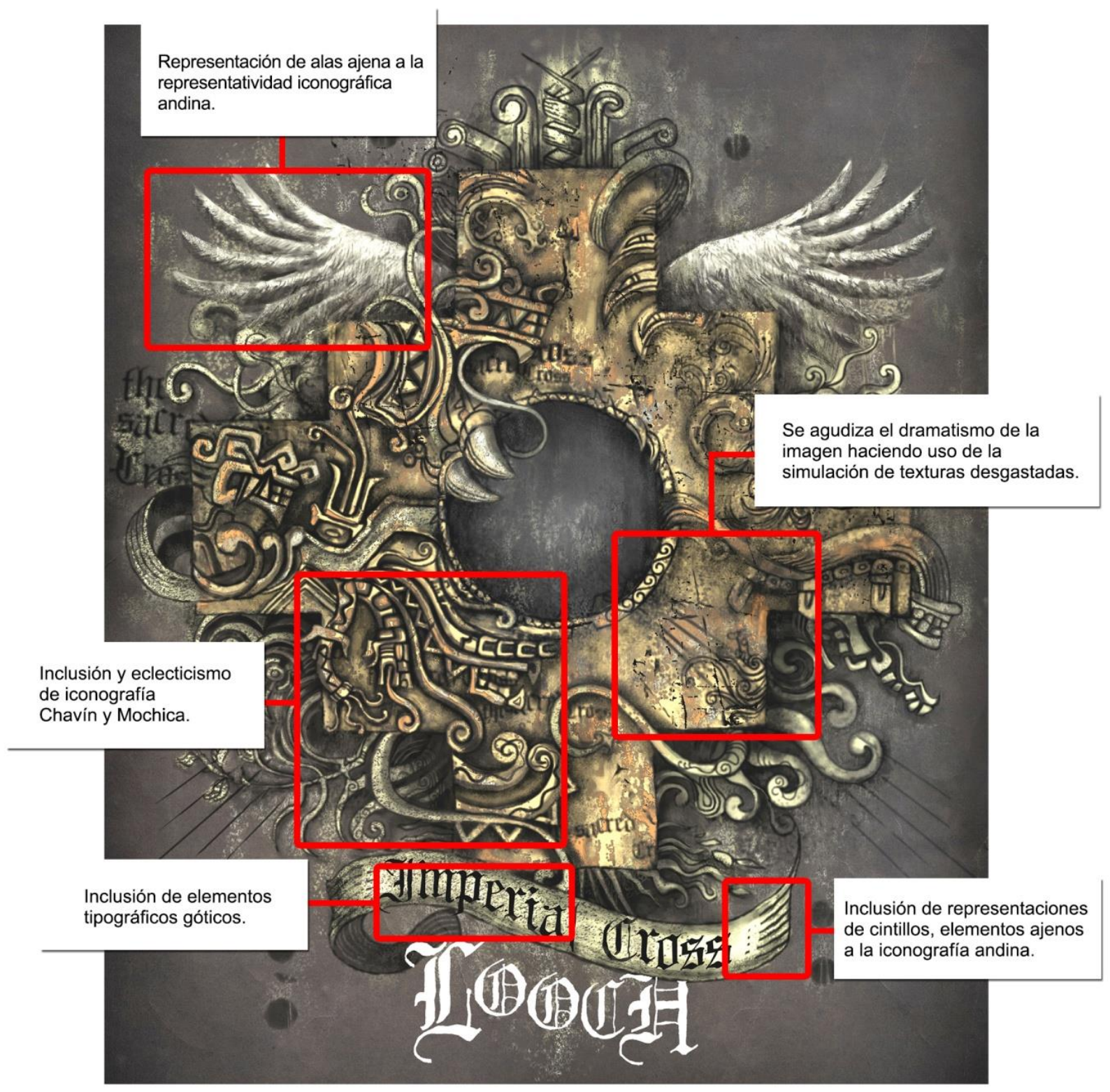

Fig. 10. Análisis visual del diseño Imperial Cross 
Habiendo concluido la fase de diseño, el próximo paso es la preparación técnica de la imagen para su impresión. La figura 11 muestra los 6 cuadros necesarios para llevar a cabo la producción serigráfica del diseño Imperial Cross sobre una tela de color gris oscuro. Los cuadros 1, 2, 3, 4 y 5 se usan para la tinta plastisol, mientras que el cuadro 6 (el que lleva el texto "LOOCH") se usa para la aplicación de un flock blanco.

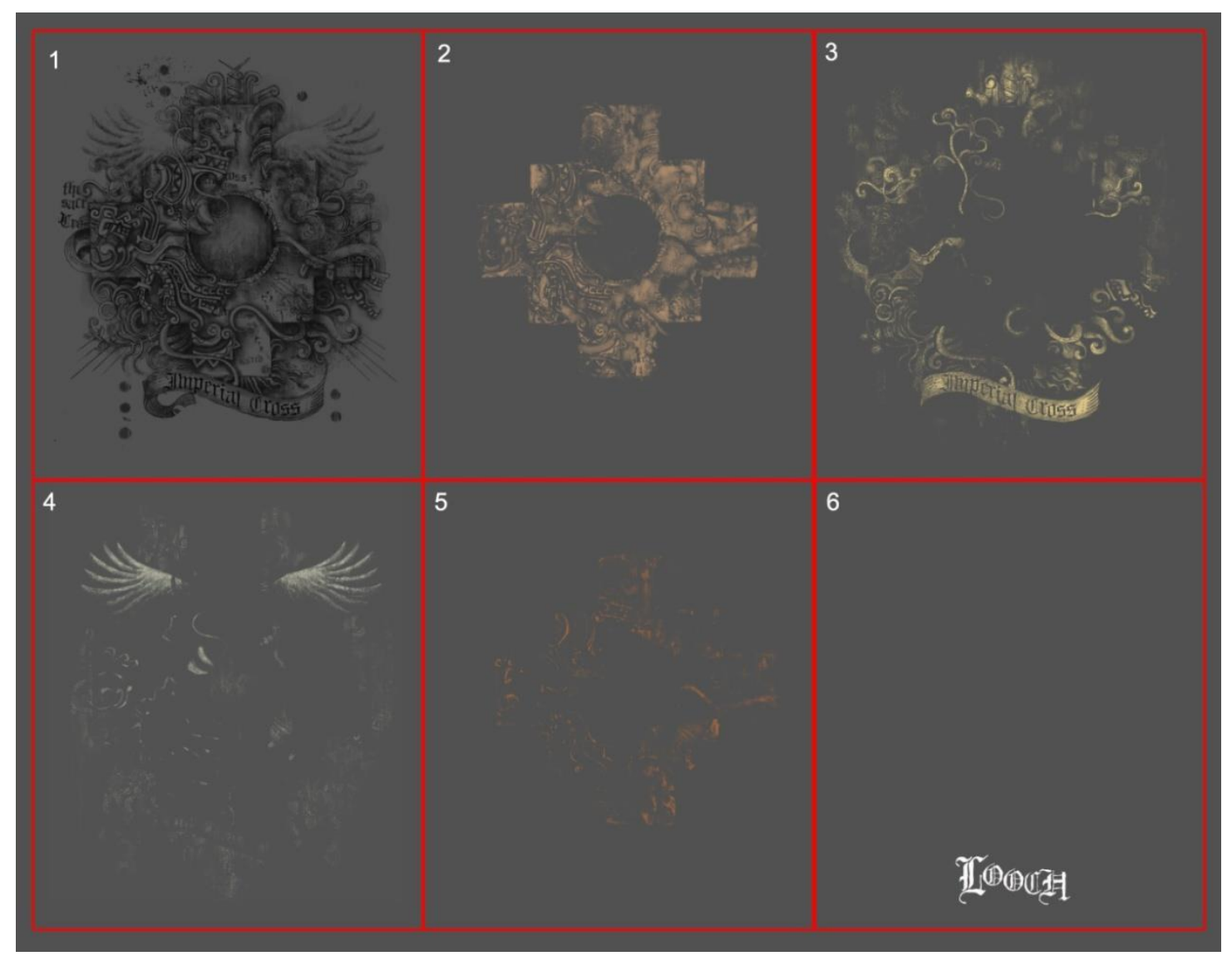

Fig. 11. Separación de colores para el diseño Imperial Cross

Luego que se resuelven los requisitos técnicos de la serigrafía, se procede a la aplicación de los diseños en los materiales o soportes que admite la marca, siendo los productos textiles (polos y poleras) los principales.

La figura 12 muestra la impresión del diseño Imperial Cross en un polo color arena y en una polera color gris claro 100\% algodón, ambos para público masculino. 


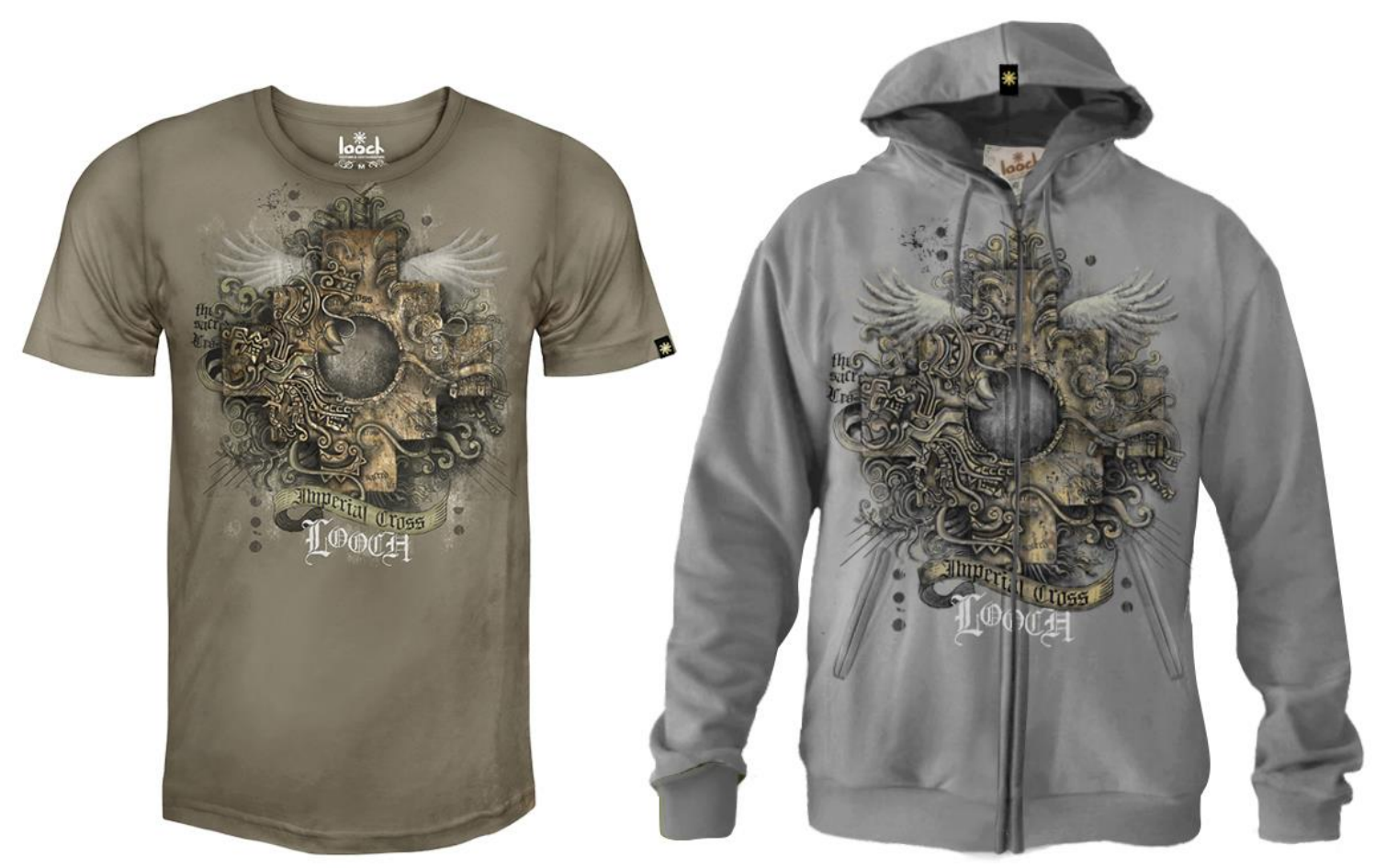

Fig. 12. Polo y polera marca Looch estampados con el diseño Imperial Cross

La prenda viene acompañada de un hangtag contraplacado y troquelado (Fig.13). En la retira se expone la imagen y en la retira se hace una breve descripción textual del mismo, junto con su correspondiente traducción en inglés.

Cruz Imperial

"La Chacana o Cruz Andina es un símbolo originario de los pueblos de los andes centrales con más de 4 mil años de antigüedad. Ha estado vinculada a interpretaciones religiosas, astronómicas, culturales y políticas, las cuales han influenciado en la concepción e imagen del mundo que tuvieron y tienen los pueblos andinos. Su composición geométrica y su simbolismo establecen la síntesis de la iconología andina, representando, principalmente, la intrínseca relación que tiene el ser humano con el cosmos". 


\section{Imperial Cross}

"The Chacana or Andean Cross is a symbol with more than 4000 years old and originally from the people of the Central Andes. It has been source of religious, astronomical, cultural, and political interpretations that have influenced in the world-view people from the Andes had, and still has. Its geometrical composition and symbolism reveal the Andean iconography synthesis, specially, the inherent relation between the human being and the Cosmos."
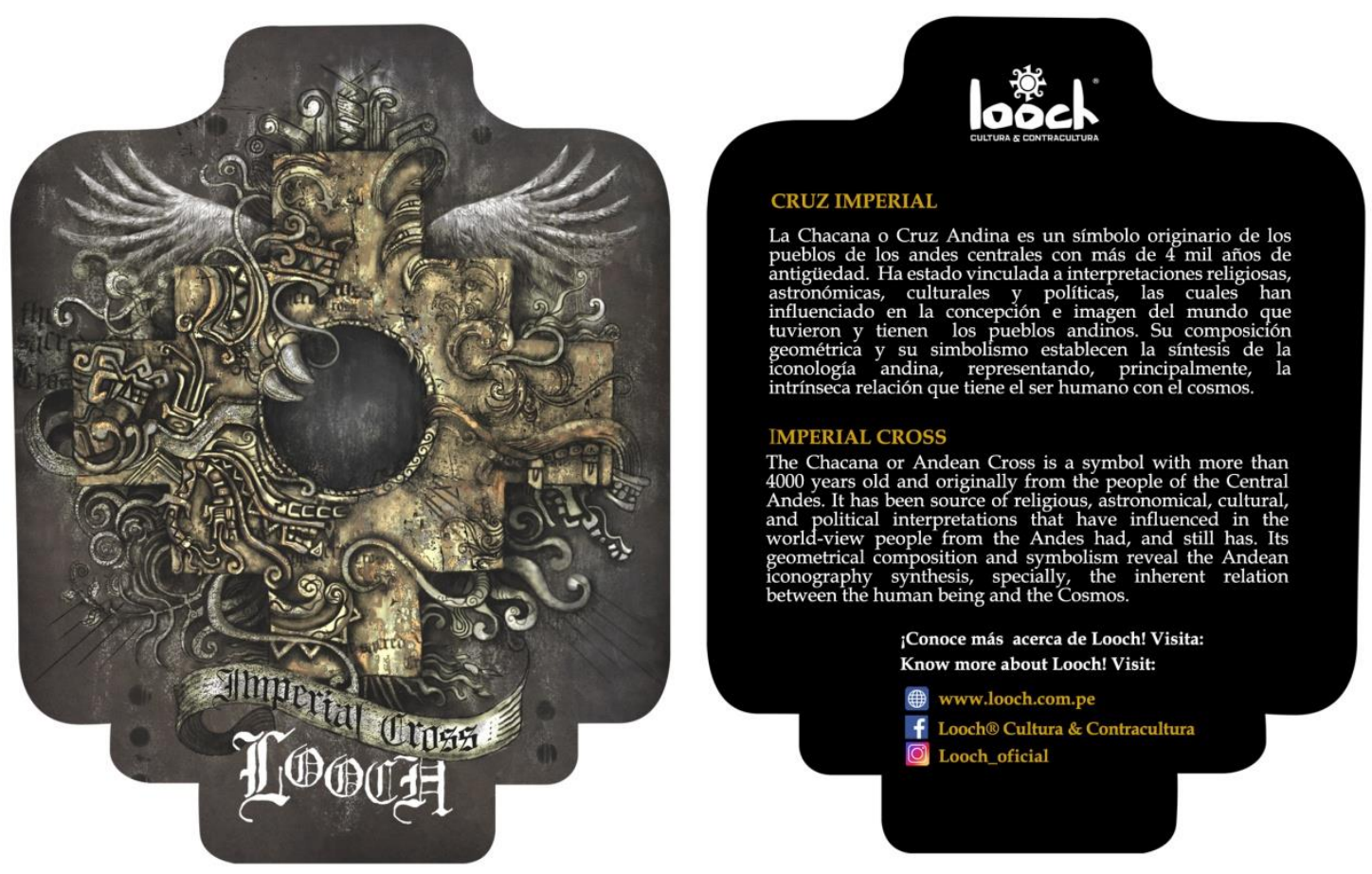

Fig. 13. Hangtag descriptivo(tira y retira) del diseño Imperial Cross

Como cierre se coloca en el hangtag una invitación para que el consumidor siga a la marca tanto en su web como en las redes sociales Facebook e Instagram.

La imagen recreada podrá ser reproducida en diversos soportes, teniendo en cuenta las consideraciones técnicas de éstos (ya sea el tamaño, el material o los costos involucrados). Fácilmente la imagen se puede reproducir en otros productos de vestir tales como bermudas o sandalias; así como en accesorios como cases de teléfonos, o en aplicación para elementos decorativos tales 
como posters o cuadros. La figura 14 muestra un ejemplo de aplicación para uso decorativo en que la imagen de la Chacana ha sido tallada en madera en alto relieve. El anexo 3 expone otras imágenes de la marca que también han sido talladas sobre madera.

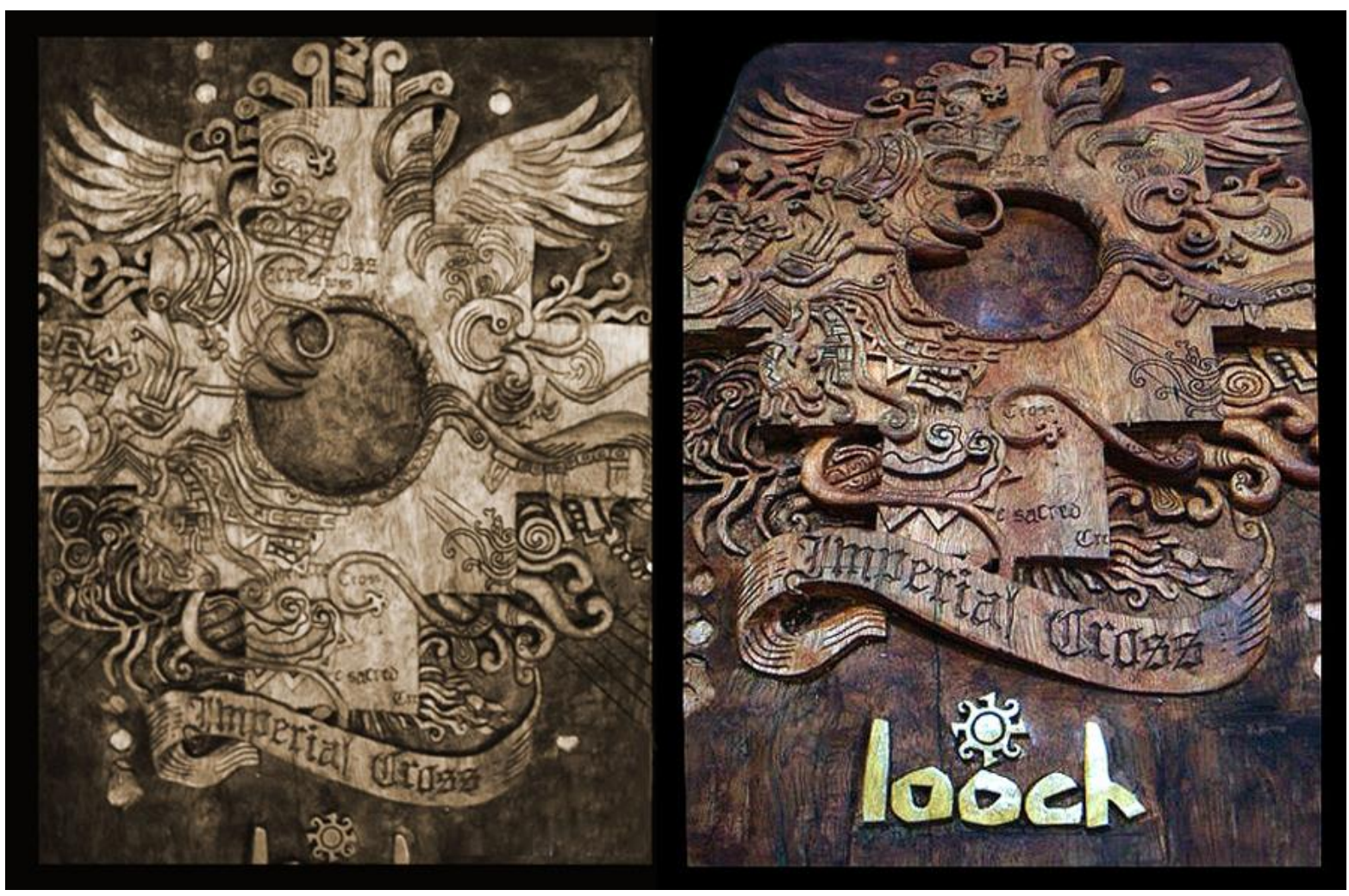

Fig. 14. Tallado en madera del diseño Imperial Cross

Este proceso, que parte necesariamente desde el entendimiento iconográfico de los temas hasta su producción en distintos soportes materiales, se repite, de manera metódica, en la creación de cada propuesta ilustrada de la marca. La figura 15 muestra otro ejemplo, en que, partiendo del tema de la cabeza clava Chavín, se ha concluido en una producción que involucra, además de las prendas de vestir y un tallado, una representación en 3D del diseño, quedando abierta la posibilidad de generar experiencias animadas. 


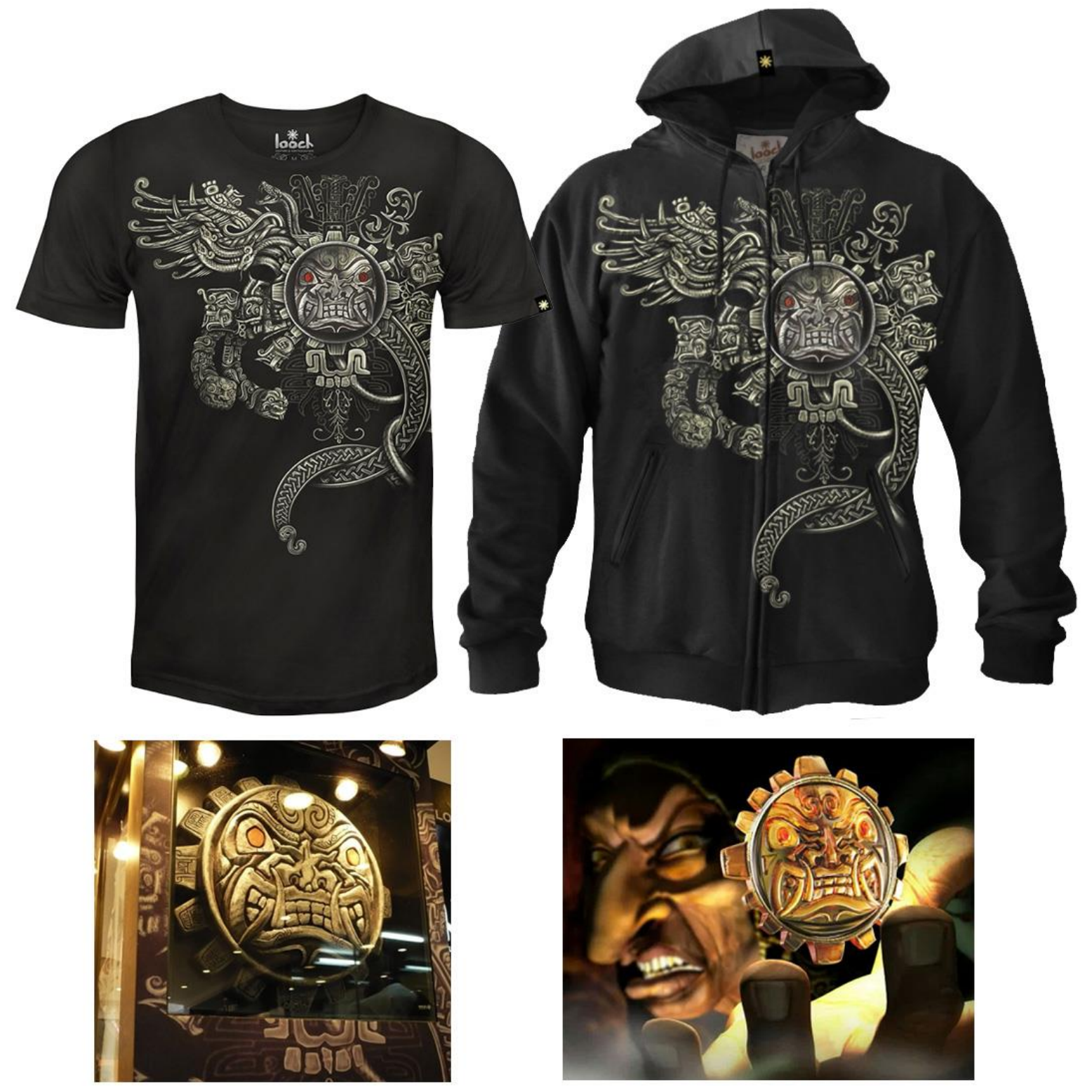

Fig. 15. Aplicación del diseño Centinelas Chavín en polo, polera, tallado y animación 3D

\section{Producción de imágenes}

La marca afianza un valor que se fundamenta en el quehacer relacionado a las imágenes propias de la iconografía ancestral peruana por lo que se constituye como un estudio abocado a tal fin, residiendo en dicha instancia su core business. Las imágenes a producir deben evocar a las impresiones, emociones o evocaciones previamente estipuladas con el propósito de generar una predisposición y conexión con su público objetivo. La puesta en valor irá en función al crecimiento de su patrimonio, es decir, a la generación de sus activos 
intangibles dados por los conceptos o ideas expresados en el lenguaje gráfico denotado por las ilustraciones. La figura 16 muestra cuatro diseños en los que los temas tratados son: el lanzón monolítico Chavín, una ceremonia de ingesta de la bebida Ayahuasca, el monstruo mitológico andino Amaru y la gobernante Mochica conocida como la Señora de Cao. Los Anexos 4, 5 y 6 muestran, de igual forma, propuestas ilustradas con temas diversos acordes a los lineamientos de la marca.
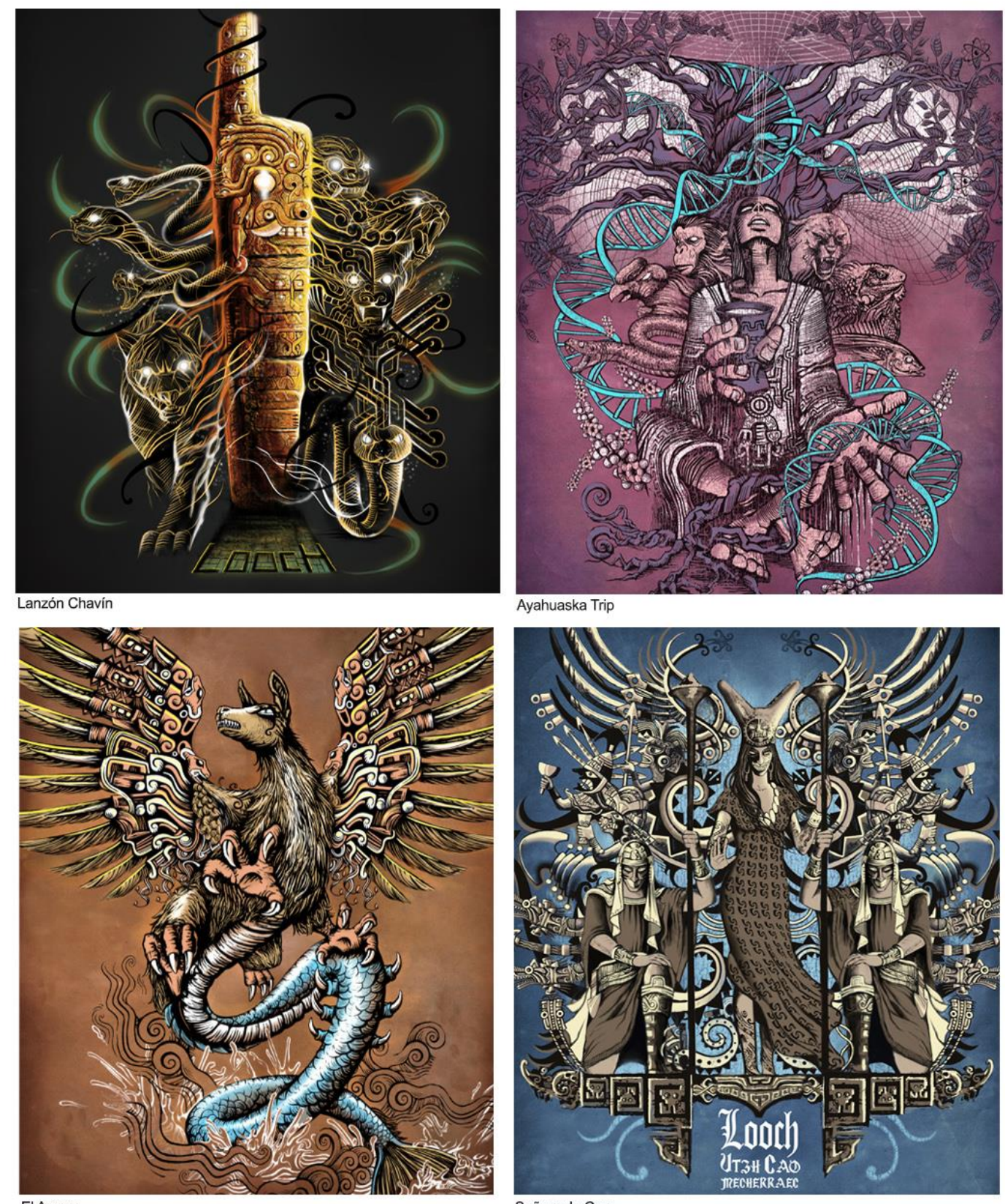

Ayahuaska Trip

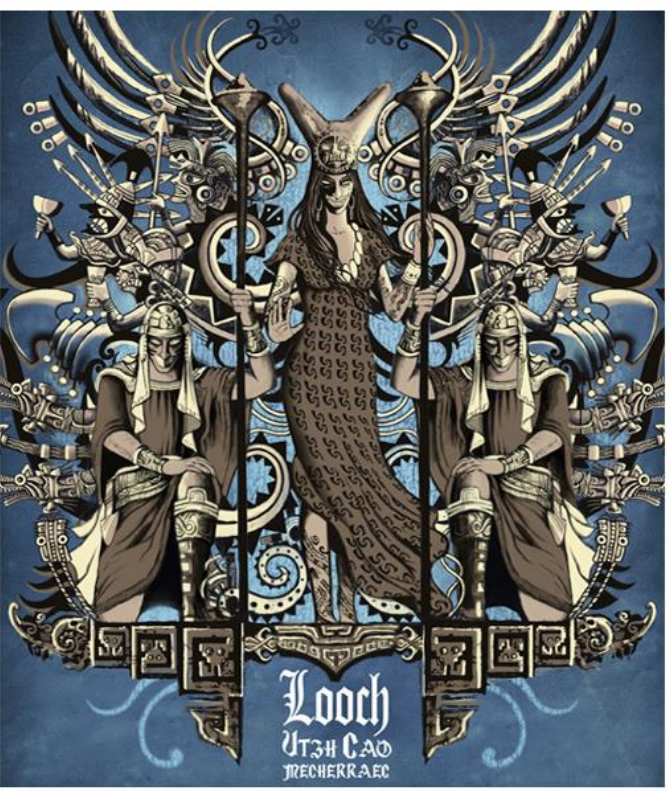

Señora de Cao

Fig. 16a. Lanzón Chavín. Fig16b. Ayahuaska Trip. Fig 16c. El Amaru. Fig16d. Señora de Cao 


\section{Uso de la marca Perú}

Acorde a los objetivos y lineamientos conceptuales del proyecto, el plan de comunicación contempla la obtención de la licencia de uso de la marca Perú, más aun teniendo en cuenta que "ser licenciatario de la Marca Perú es unirse al esfuerzo para promover la imagen positiva de nuestro país a nivel nacional e internacional". Para tal efecto, las imágenes de la marca deben ceñirse a las disposiciones visuales establecidas en el manual de uso de la marca Perú. La figura 17 muestra un ejemplo de ello: la sección inferior de la imagen muestra tanto al logotipo de la marca Perú como a los elementos geométricos que sirven de soporte visual y compositivo, acorde a la imagen de la misma.

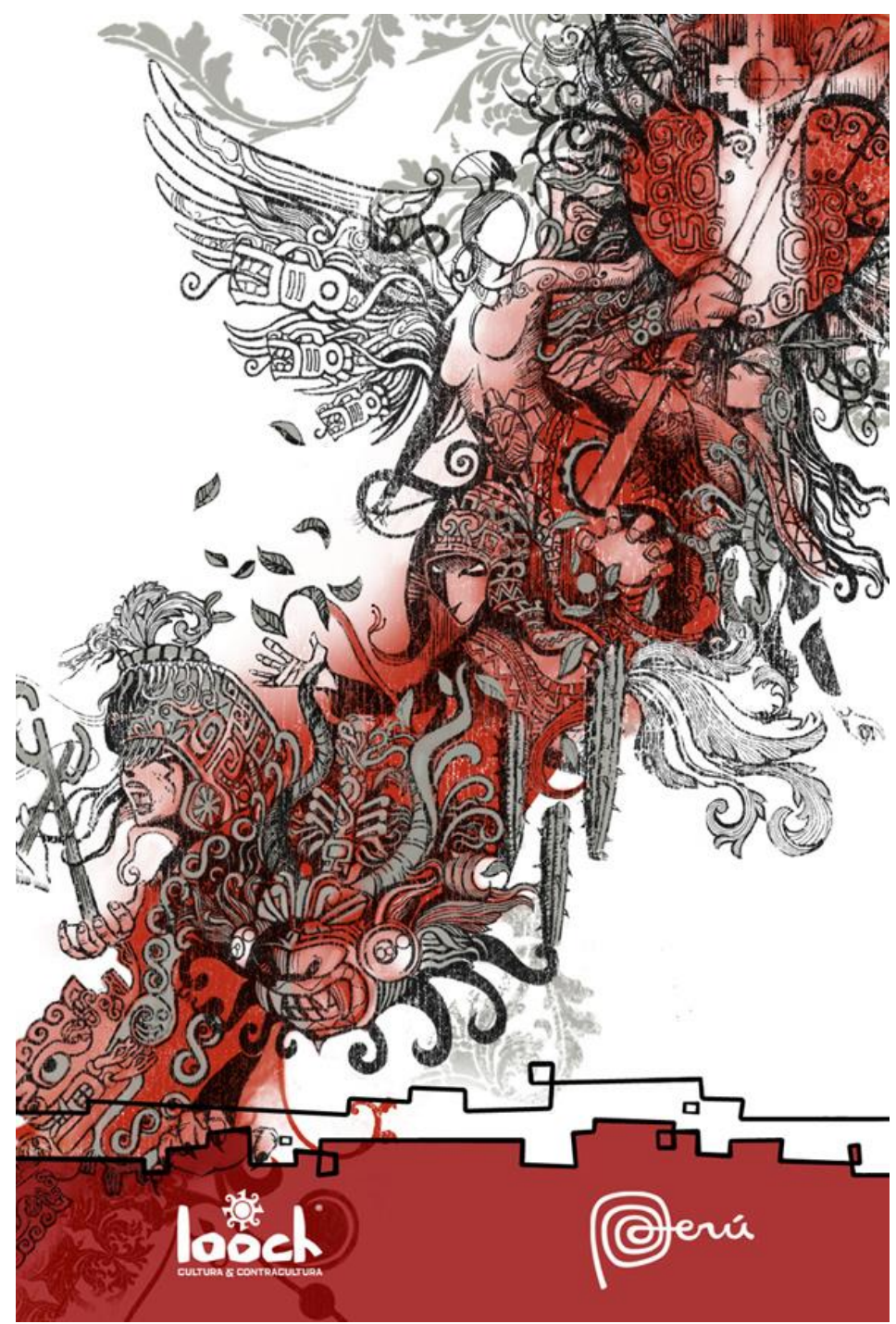

Fig. 17. Aplicación de la Marca Perú al diseño La Franja 


\section{Puntos de venta}

Para la colocación del producto en el mercado se procedió a la instalación de puntos de venta en el formato de módulos de $2 \times 2.5$ metros en distintos centros comerciales en Lima y provincias. El diseño de los módulos obedece no solo a los criterios de la marca sino también a los lineamientos estéticos y pragmáticos que exige cada centro comercial. Algunos de estos módulos se muestran en la figura 18 (Real Plaza Arequipa, Real Plaza Centro Cívico, Real Plaza Chiclayo, Plaza Norte). Asimismo, se trabajaron modalidades de consignación y venta con distribuidores a nivel nacional (Figura 19).

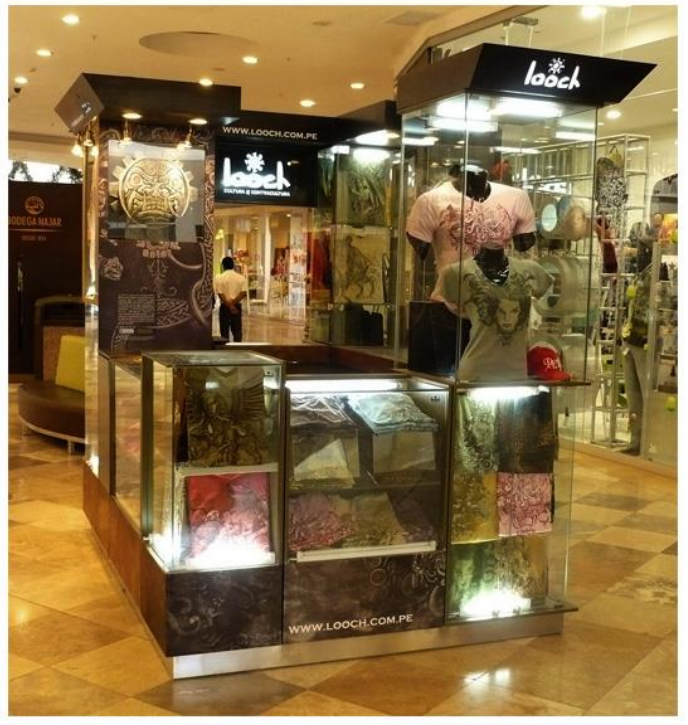

Real Plaza Arequipa

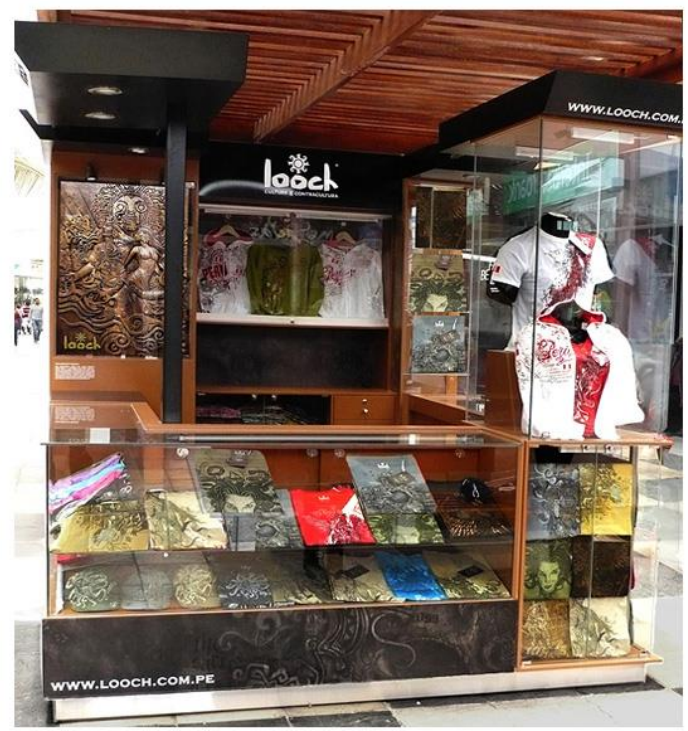

Real Plaza Chiclayo

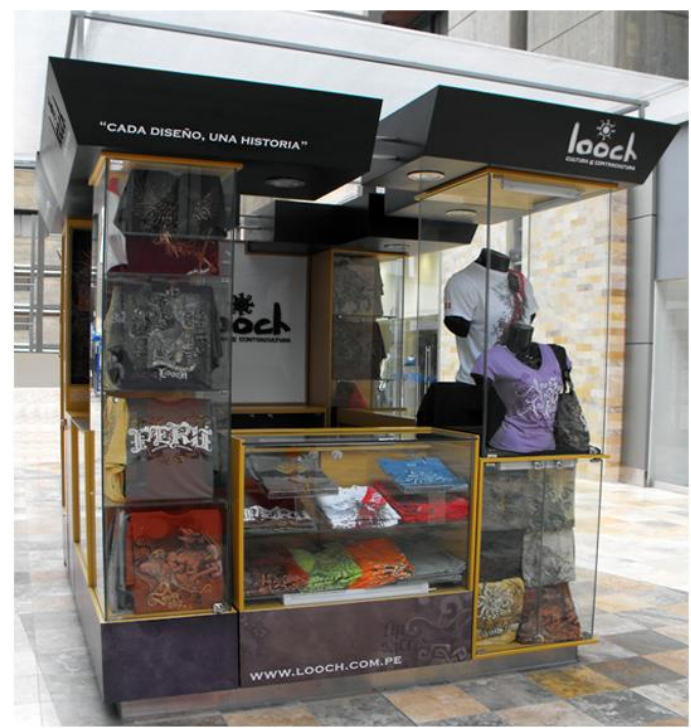

Real Plaza Centro Cívico

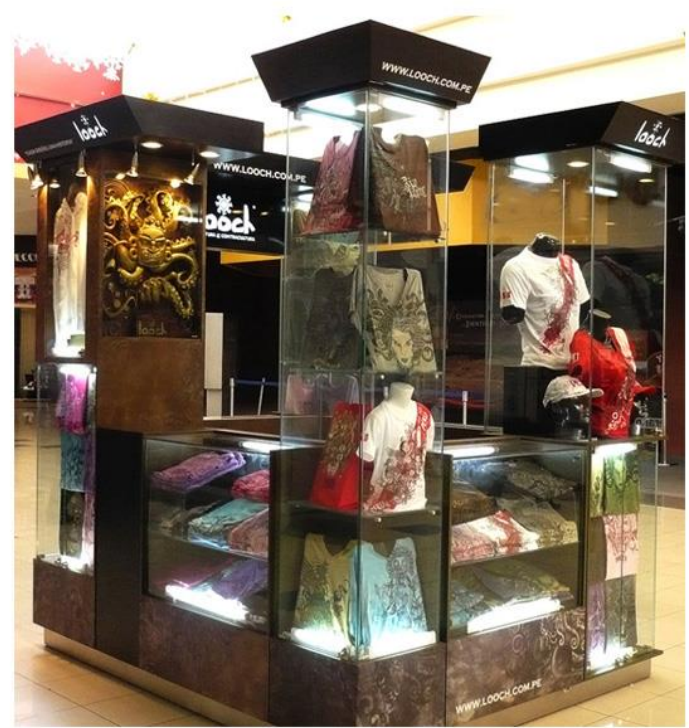

Plaza Norte 
Fig. 18. Puntos de venta de Looch en centros comerciales

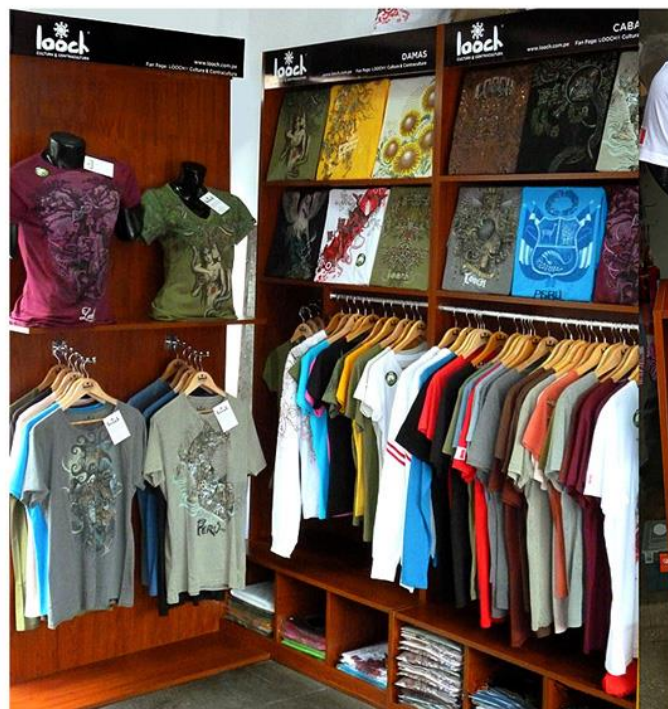

Av. Benavides, Surco

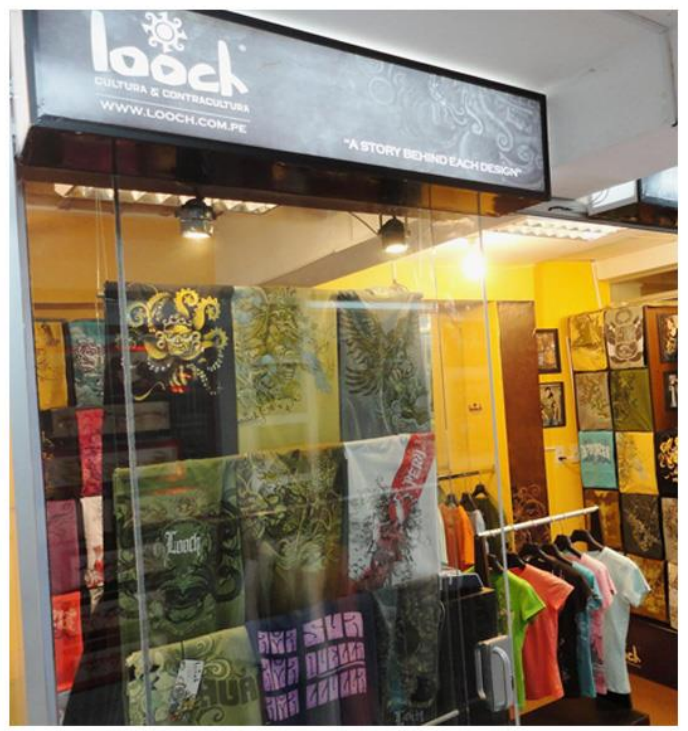

San Blas, Cusco

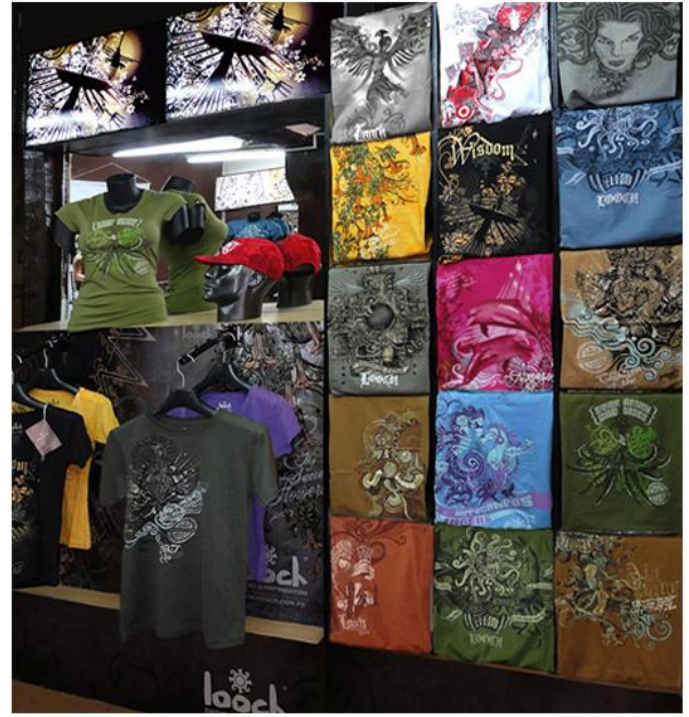

Av. Ricardo Palma, Miraflores

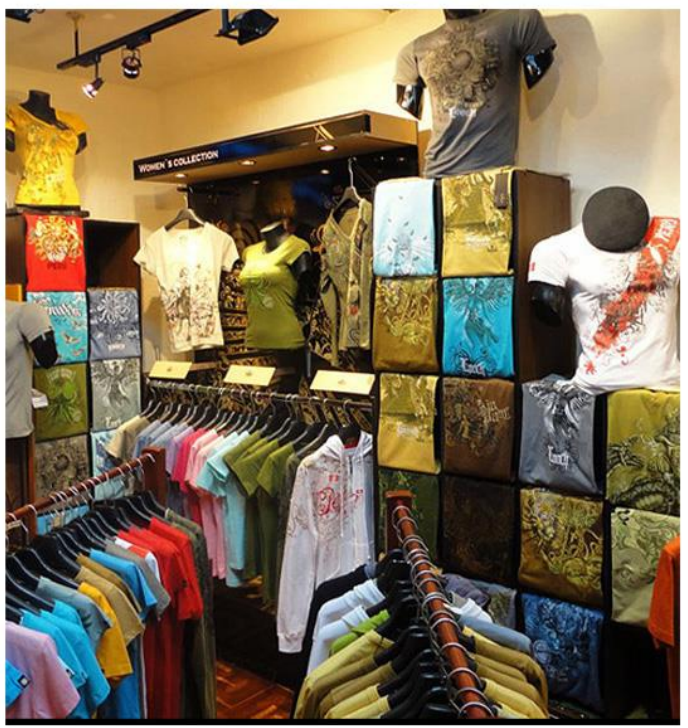

Procuradores, Cusco

Fig. 19. Distribuidores de Looch

\section{Presencia en redes sociales}

El desarrollo de la tecnología ha permitido no solo un gran despliegue de los medios de información, sino que también ha afectado la dimensión cultural de las sociedades. Dado que la tecnología se desarrolla de manera transversal con el fenómeno de la globalización afectando a la cultura de masas, es que 
aparece el término especializado media culture para referirse a aquel espectro en el que el uso de la tecnología modula, construye y define el devenir de la cultura. En tal sentido, las redes sociales se han convertido, en el lapso de pocos años, en un fenómeno global cuyo potencial de comunicación ha de ser aprovechado para los propósitos de la marca. Las redes sociales a considerar, debido a su impacto visual y a su popularización son las siguientes: Facebook (Fig.20), Pinterest (Fig. 21) e Instagram (Fig. 22)

\section{Facebook}

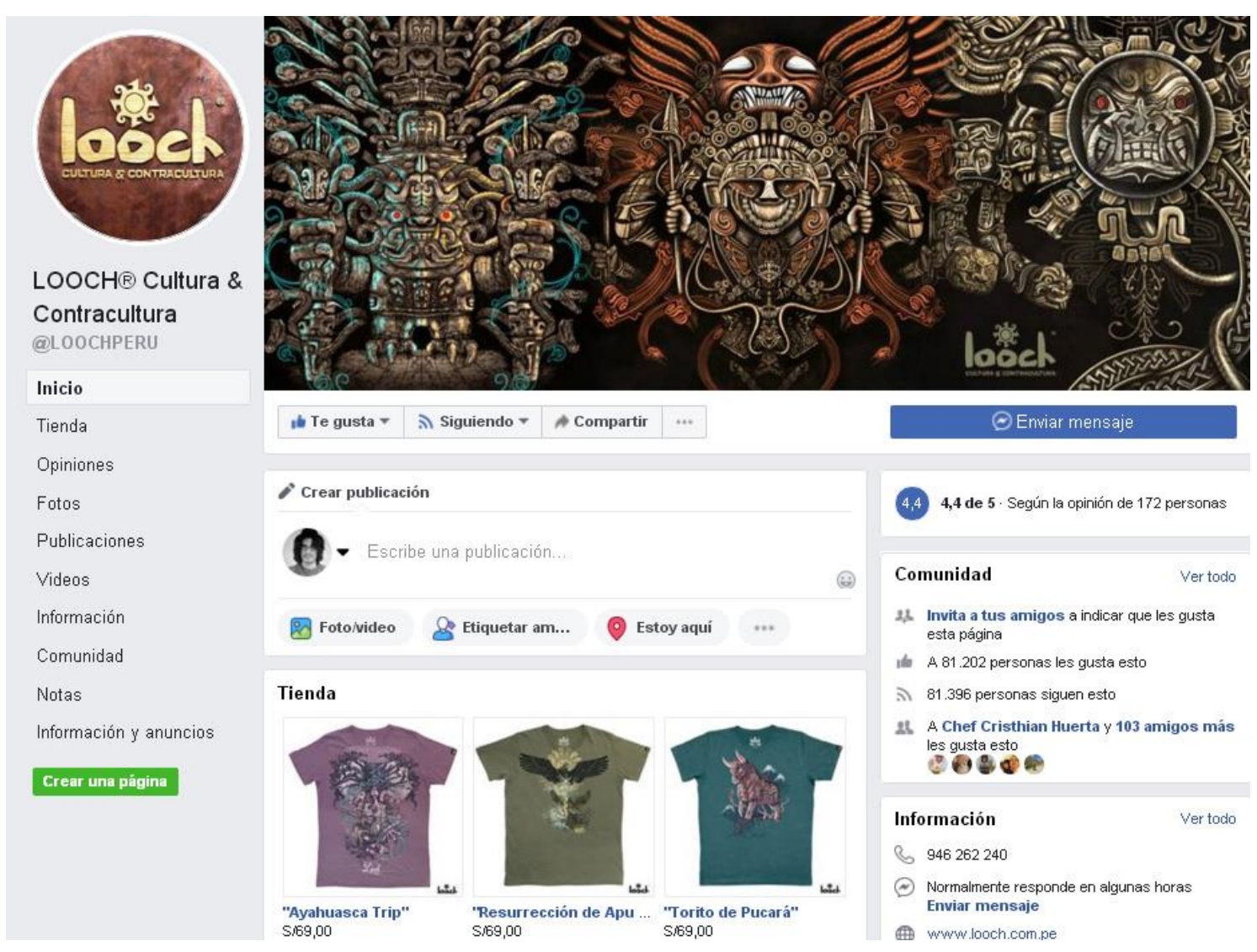

Fig. 20. FanPage de Looch en Facebook 


\section{Pinterest}

ค Q Buscar

\section{Looch}

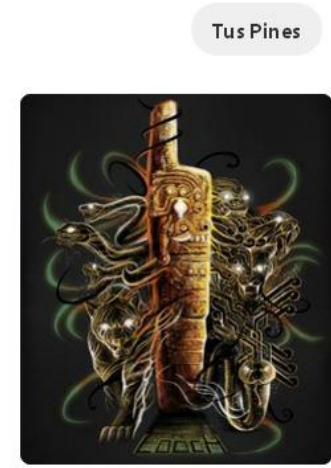

Lanzón Chavín. Looch.

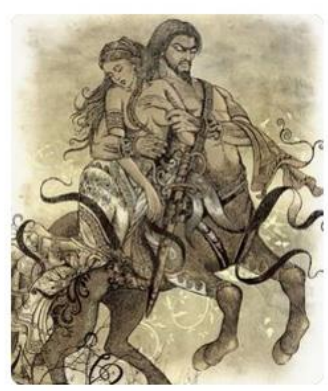

Rapto de Deyanira . Looch

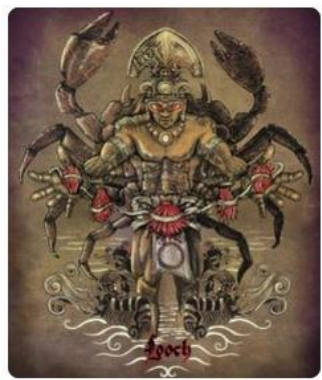

Lang Nam. Looch.

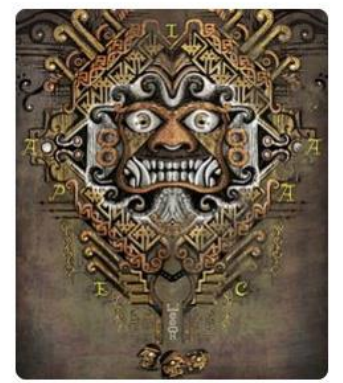

Aia Paec. Looch.

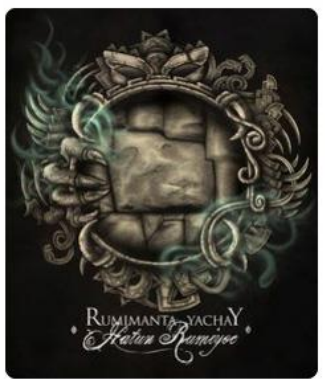

Rumimanta Yachay . Looch.

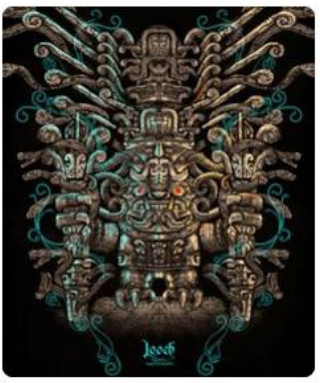

Etela Chavin. Looch
Inicio ${ }^{\bullet}$ Siguiendo

loct) Looch : $\div$
H $\#$ Organizar

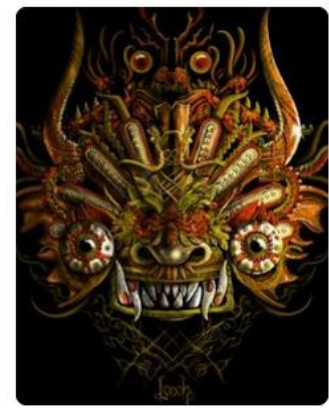

Supay. Looch.

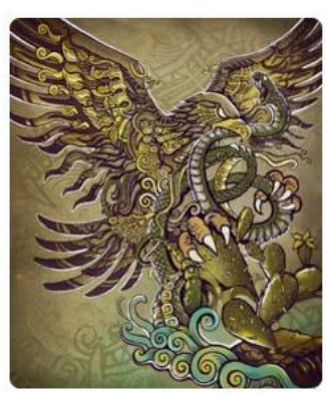

Tenochtitlán. Looch

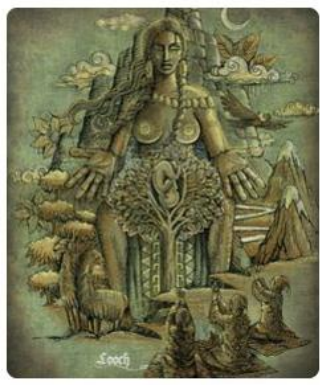

Madre Tierra. Looch.

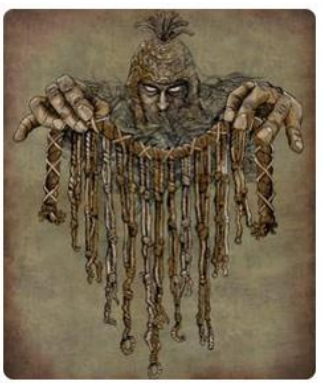

Quipu. Looch.

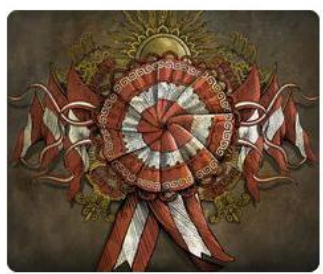

Ecarapela . Looch.

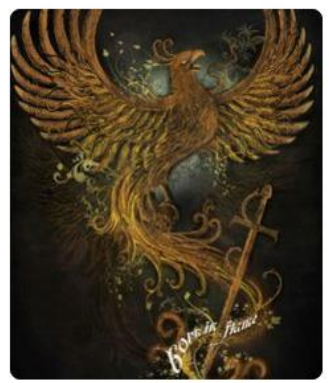

Phoenix. Looch.

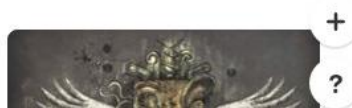

Fig. 21. Pinterest de Looch 
Instagram

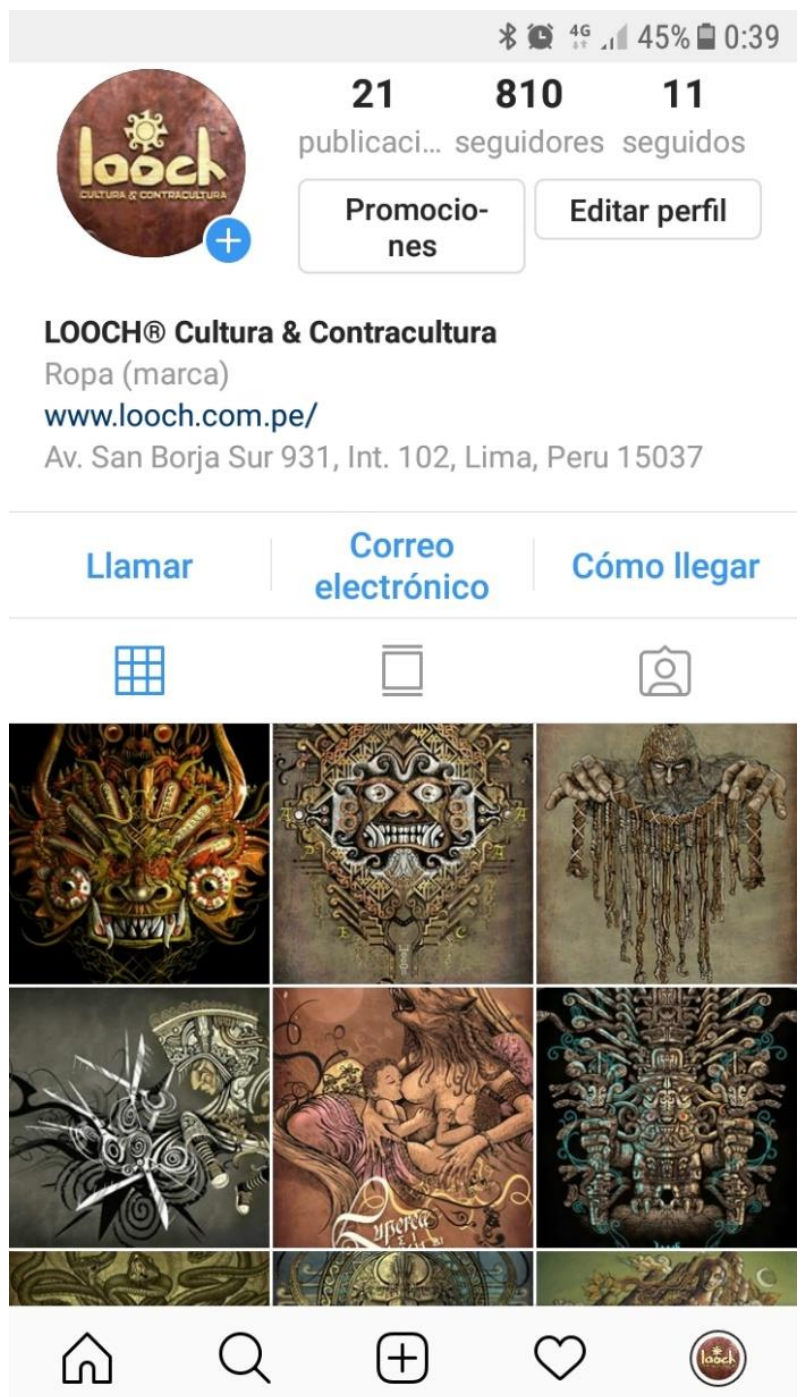

Fig. 22. Instagram de Looch

\section{Publicidad impresa}

La publicidad impresa tiene fines diversos, acordes a los objetivos particulares de las campañas que la produce, tales como: estimular el incremento de ventas, mejorar la imagen corporativa, lanzar nuevos productos, dirigir campañas promocionales, etc. Para la comunicación se hará uso de volantes, dípticos, trípticos, brochures, banners, posters, jalavistas, etc. Estas se 
colocaran en puntos de venta, canales de distribución, franquiciados, ferias, etc. Los elementos gráficos necesarios para el desarrollo de las piezas publicitarias son: fotografías de los productos, fotografías de modelos (hombres y mujeres) e imágenes de las ilustraciones. A continuación se exponen algunas de estas piezas: díptico informativo (Fig. 23), brochure a modo de catálogo (Fig. 24) publicidad para revista (Fig. 25), banners y afiches (Fig. 26), entre otros.

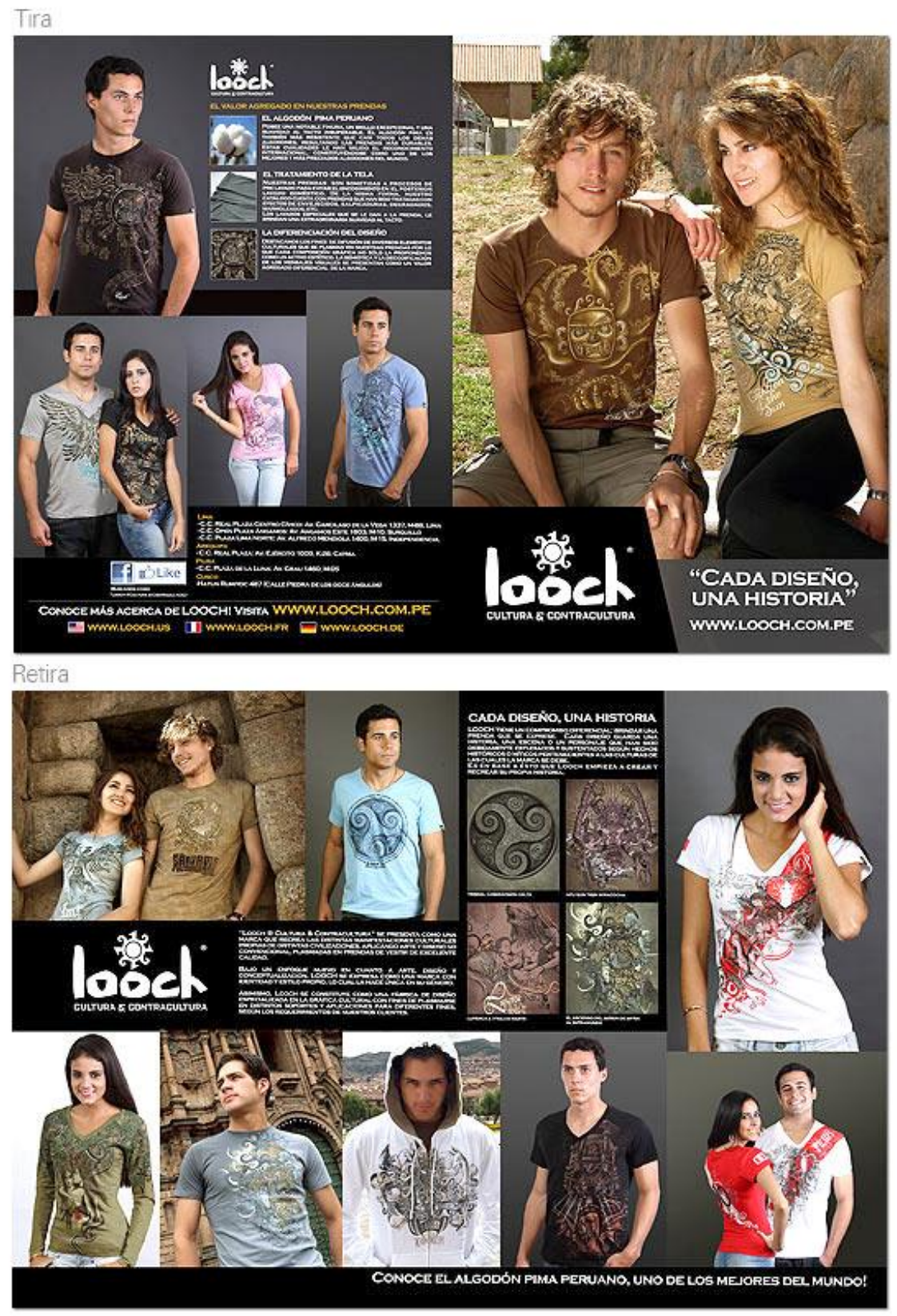

Fig. 23. Díptico publicitario (tira y retira) de Looch 

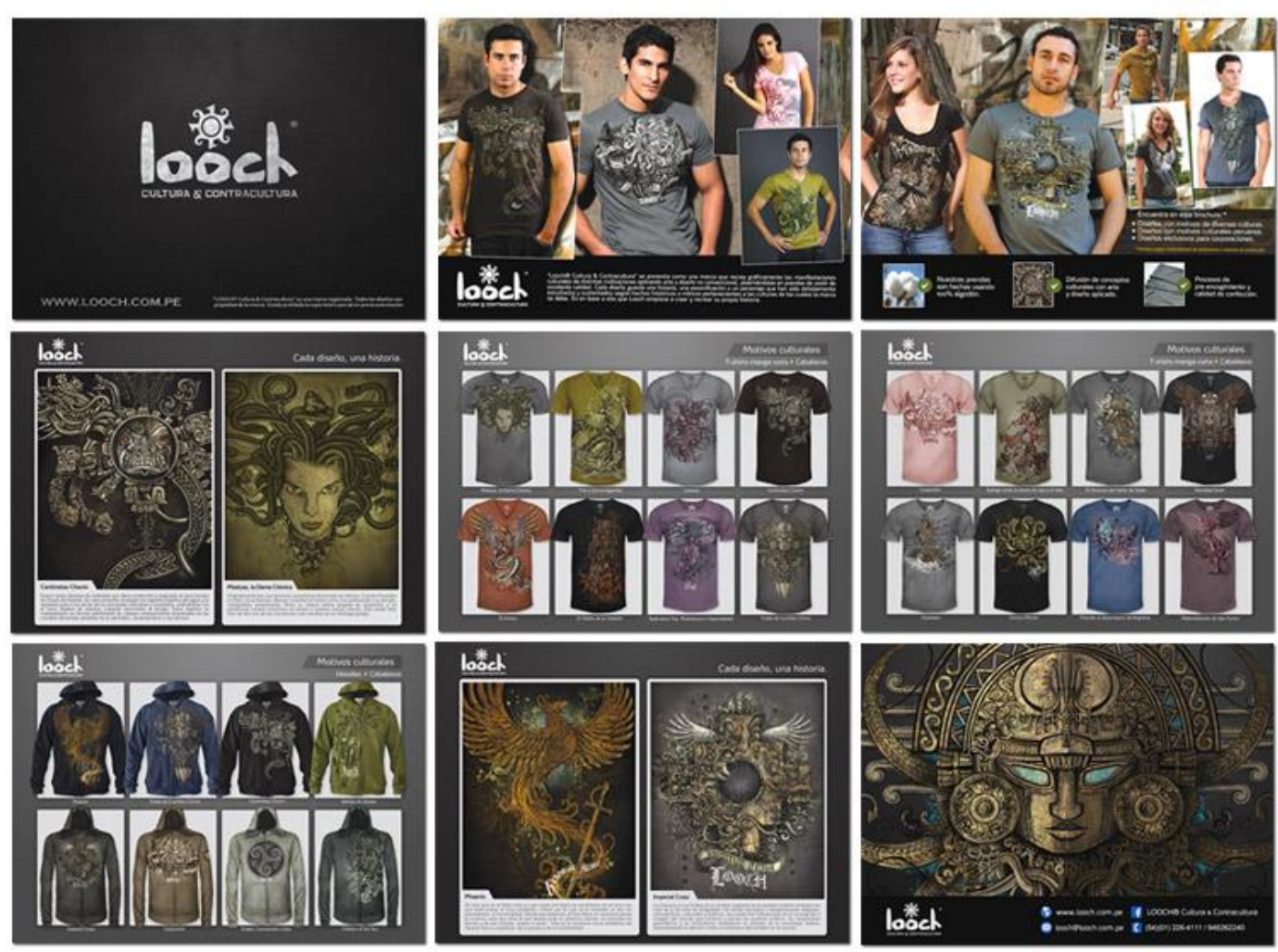

Fig. 24. Vista parcial de brochure a modo de catálogo de Looch

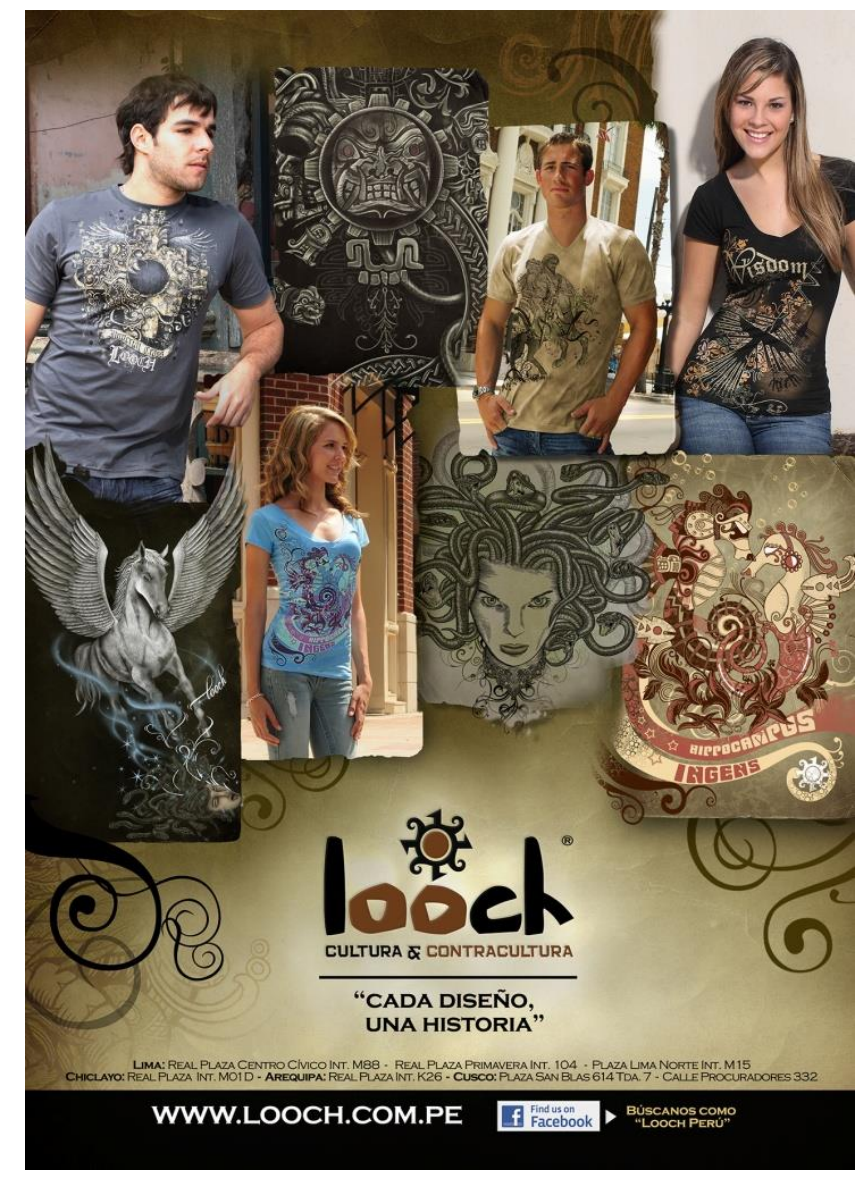

Fig.25. Anuncio de revista de Looch 

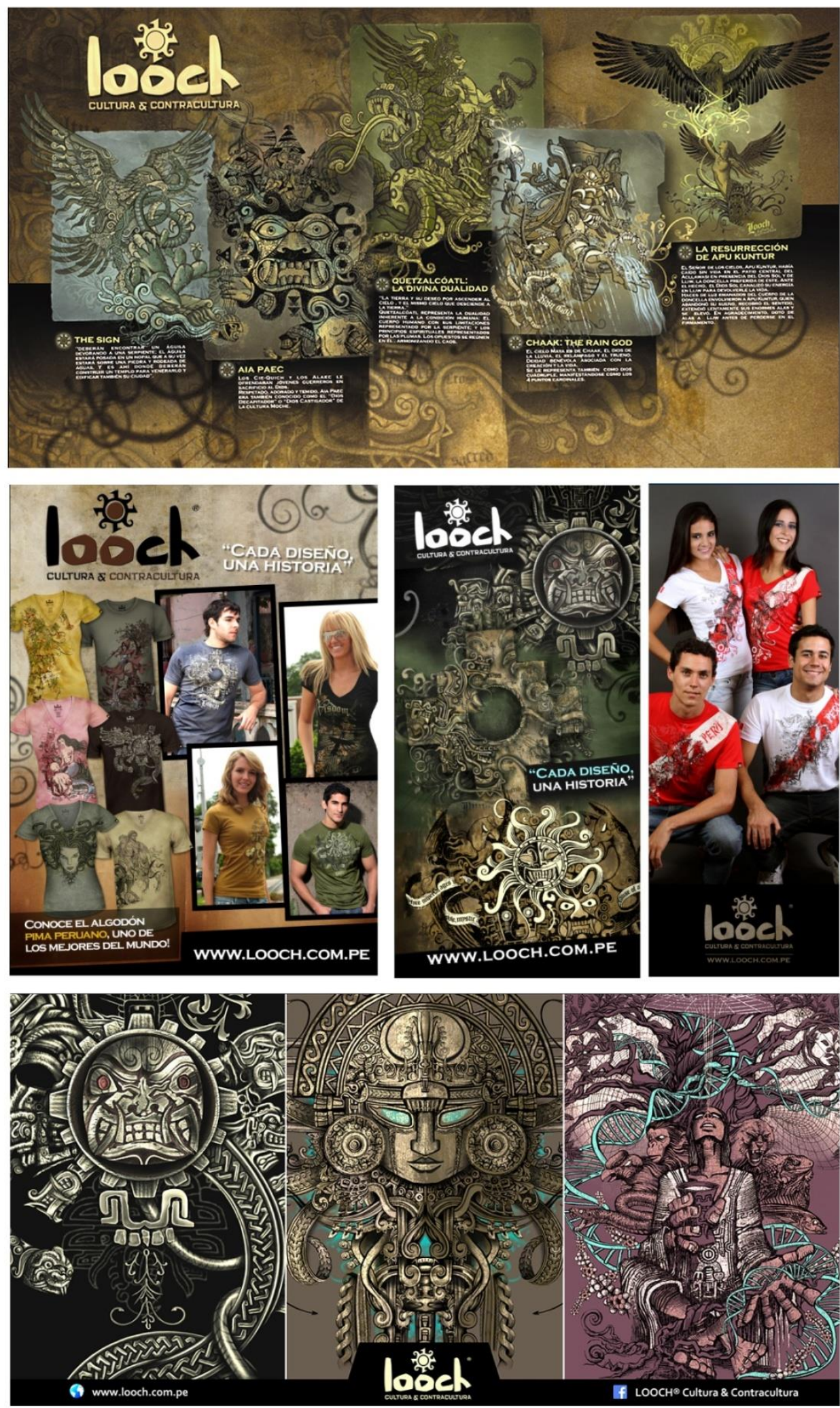

Fig.26. Banners y afiches publicitarios de Looch 


\section{Publicidad digital}

A mediados de la década de los 90, la publicidad digital empezó a ser tomada en consideración. Con la creciente demanda de construcción de páginas web, no solo como medios informativos, sino también como estrategias de imagen corporativa y de publicidad para instituciones y corporaciones, los recursos relacionados no tardaron en aparecer. Los banners digitales, los pop-ups, las búsquedas pagadas y la inversión monetaria a cambio de clics fueron hasta finales del siglo pasado los recursos más usados. La mejora y la afinación de los medios permitieron la consideración y el desarrollo de anuncios de menor intromisión y además, usando la segmentación del público objetivo. Posteriormente, hizo su aparición la publicidad nativa y las redes sociales.

\section{E-mailing marketing}

Dentro de las múltiples posibilidades que ofrece la publicidad en medios digitales, los e mailing masivos han sido uno de los recursos publicitarios mas usados, sin embargo, resulta siendo invasivo, pudiendo generar molestia en los receptores. El e-mailing marketing, a diferencia del emailing masivo, es enviado en función a una CMR (Customer Relationship Management, o Gestión de las relaciones con clientes), desde la cual se seleccionan a clientes fidelizados o clientes potenciales de una base de datos. Este tipo de mailing es usado por Looch, acorde a la información de clientes proveniente de una base de datos. La información enviada en el mailing toma en consideración el perfil y los intereses de dichos clientes para ponerlos al tanto de información actualizada, novedades, promociones y campañas de descuento que ofrece la marca. La figura 27 muestra un mailing de formato vertical, en el que se expone una campaña de descuento del $30 \%$ en productos seleccionados. La plataforma usada para mandar dichos e-mailings fue MailChimp. 

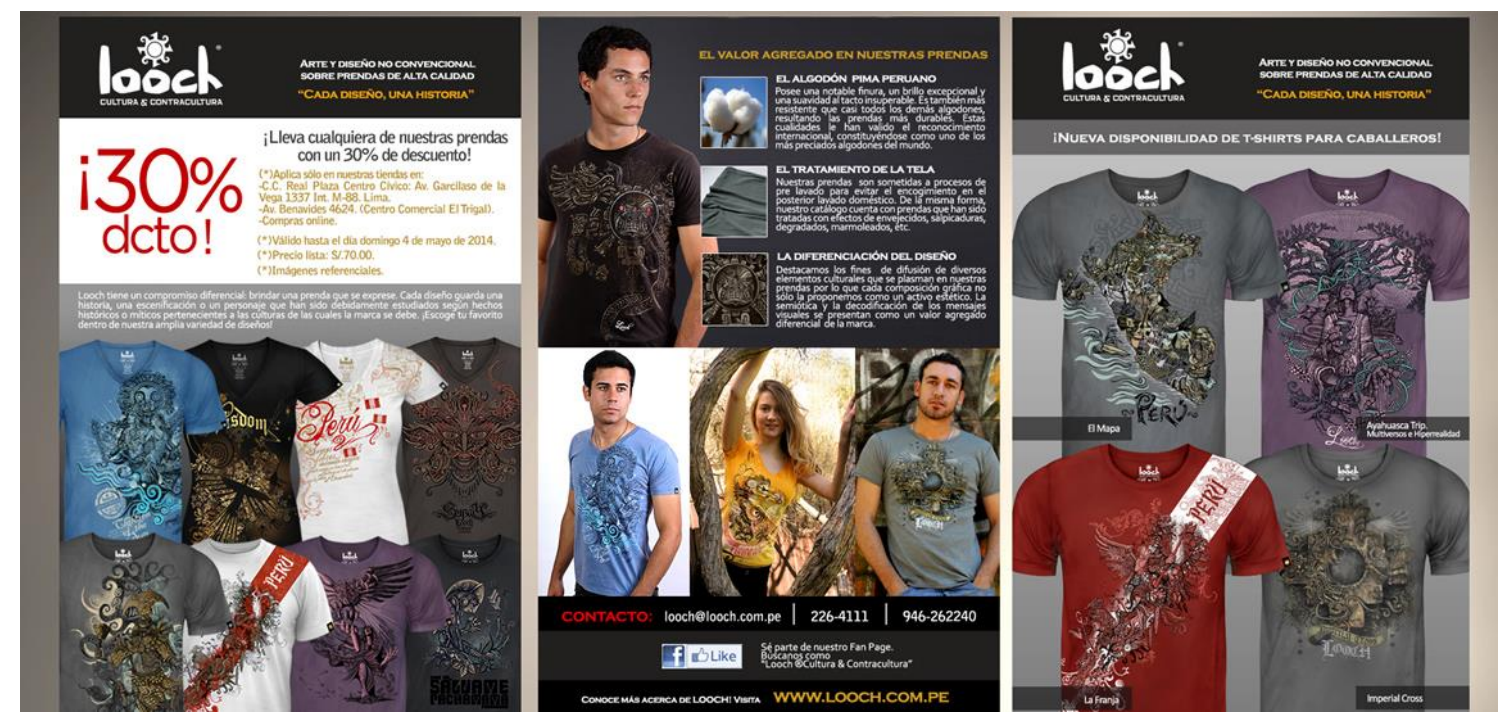

Fig. 27. E-mailings publicitarios de Looch según el formato de MailChimp

\section{Plataformas de comercio electrónico}

Las transacciones de compra y venta de productos y servicios haciendo uso de internet $u$ otras redes informáticas, es conocido como ecommerce. Esta modalidad de comercio ha experimentado un crecimiento considerable desde que hizo su aparición a mediados de la década de los 90, permitiendo la innovación tecnológica en cuanto a transferencia de fondos, el marketing digital, las transacciones en línea, los sistemas administrables para administración de stock, o la sistematización y automatización de datos, entre otros. Con ello, las modelos tradicionales de concretar negocios han ampliado sus límites convencionales, permitiendo incluso beneficios tanto para las empresas como para los usuarios, tales como reducir costos, minimizar los tiempos de entrega o facilitar la comunicación con los clientes.

En ese sentido, la marca hará uso no solo de canales de venta físicos (tiendas en centros comerciales $y /$ canales de distribuidores) para hacer llegar el producto a su público sino que el auge del e-commerce le permite una oportunidad para expandir su mercado y generar nuevos vínculos comerciales.

Las plataformas a considerar para exponer los productos a su precio lista fueron Mercado Libre (Fig. 28) y Linio (Fig. 29), mientras que se usó la 
plataforma Cuponidad (Fig. 30) para brindar a la clientela altos descuentos en los productos con la finalidad de generar tráfico y publicidad a la marca.

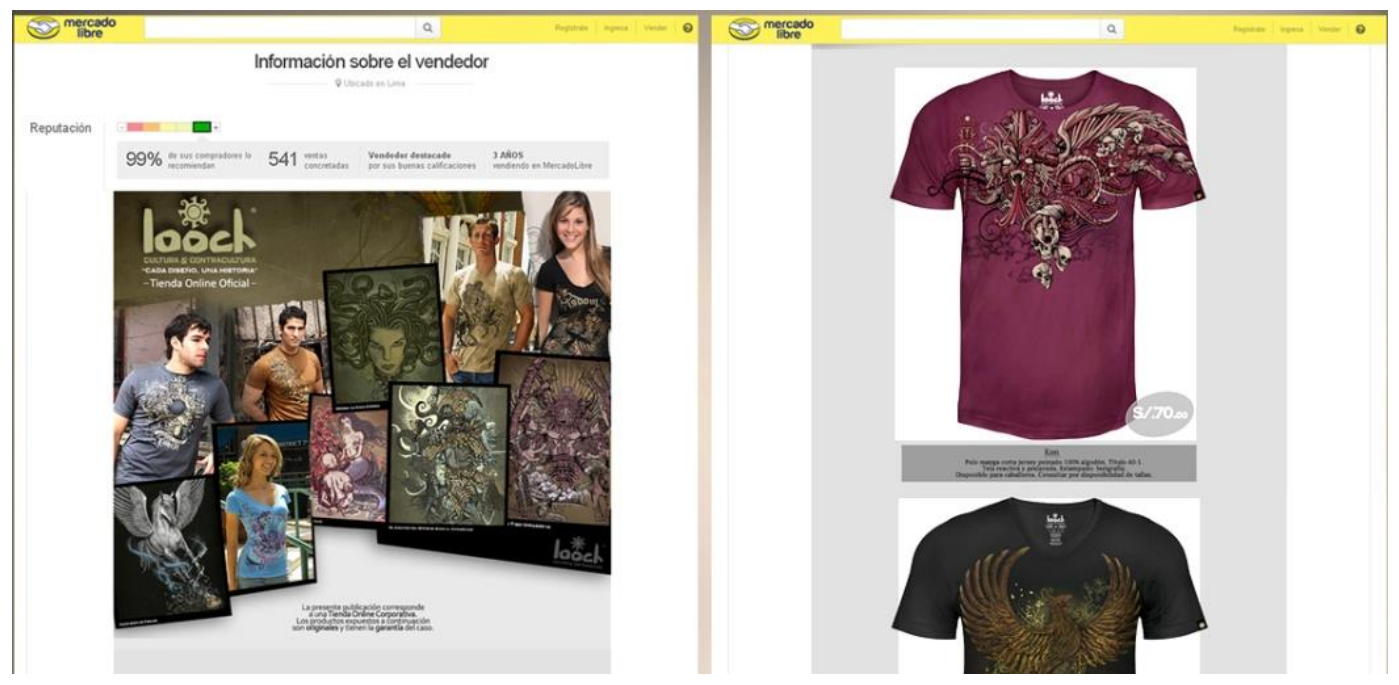

Fig. 28. Presencia de Looch en Mercado Libre

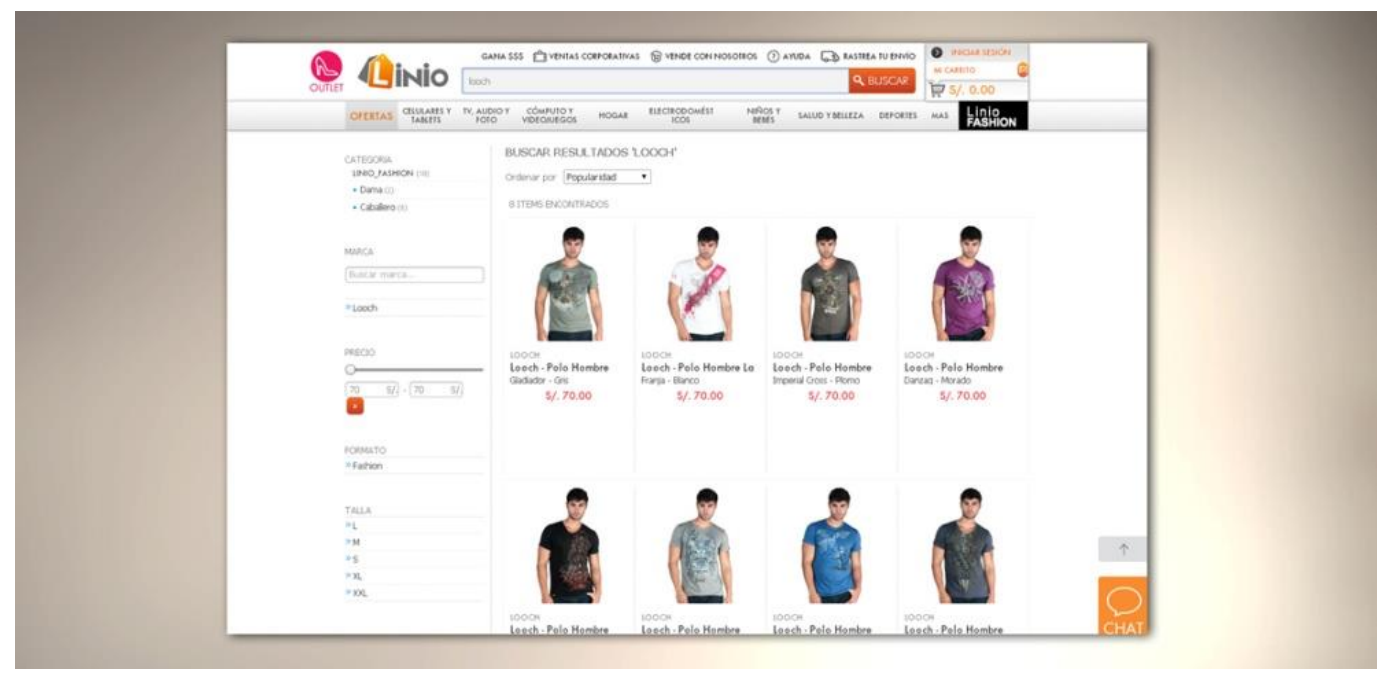

Fig. 29. Presencia de Looch en Linio 


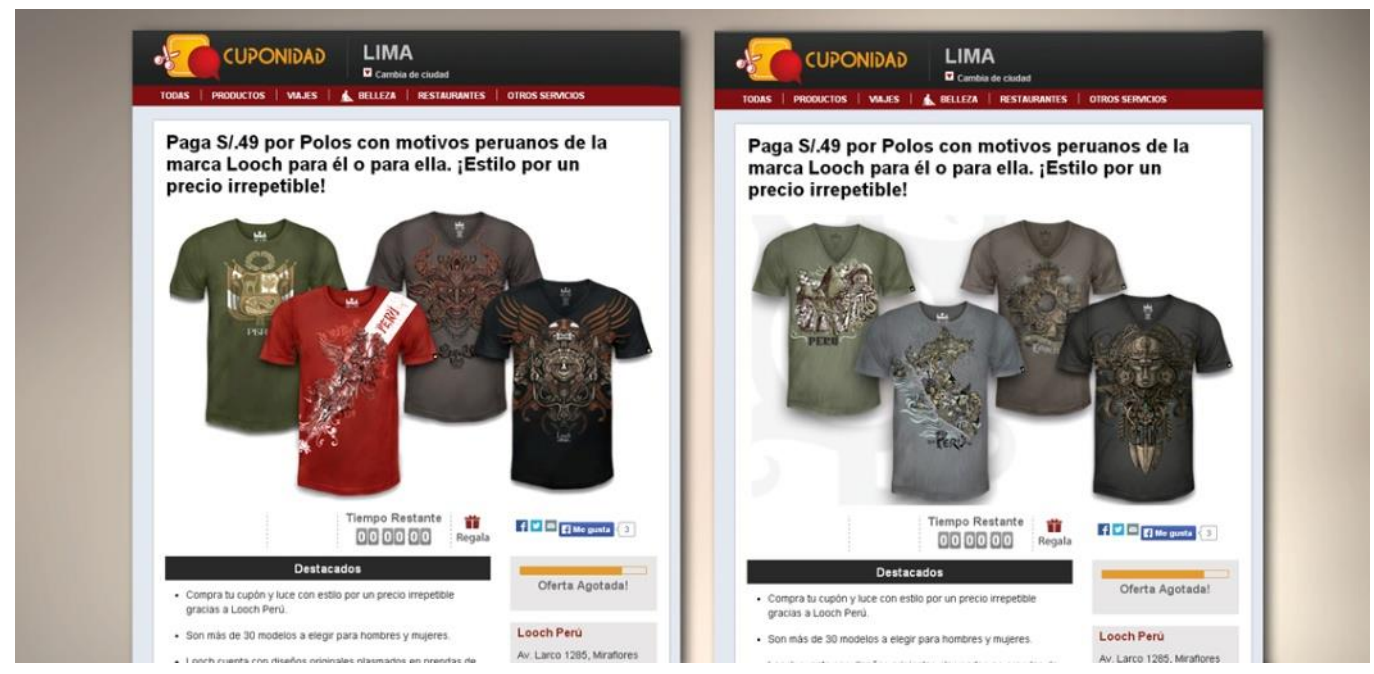

Fig. 30. Presencia de Looch en Cuponidad

\section{Campañas publicitarias en Facebook}

Con fines de promover la relación con los seguidores en la red social Facebook, se publican, de manera periódica, concursos y promociones invirtiendo una cantidad monetaria en su impulso para que pueda llegar a un segmento más amplio de consumidores.

Los concursos promueven no solo la participación lúdica, sino también el interés por la identificación de la iconografía peruana a cambio de obsequios, descuentos o vales de compra. La figura 31 muestra un concurso en el cual se invita a predecir el resultado de un encuentro de futbol entre las selecciones de Perú y Uruguay, mientras que la figura 32 incentiva a los seguidores a despertar la curiosidad respecto a la identificación de 4 deidades andinas.

Por otro lado, las promociones publicadas en Facebook ofrecen envíos gratis, campañas de descuento o el incentivo de un regalo por cierta cantidad de productos, tal como un $3 \times 2$. La figura 33 muestra este tipo de publicidades promocionales. 


\section{lood

¿Listos para alentar a Penú este viernes?

¡Danos tu pronóstico del resultado y de los autores de los goles del partido Perú - Uruguay!

Entre los participantes que acierten con el resultado, sortearemos 02 potos $100 \%$ algodón pirna con el điseño "La Franja" (1 polo para damas para una ganadora y 1 polo para varones para un ganador). Si además del resultado aciertan con los nombres de los autores de los gotes.

regalaremos 02 polos adicionales para cada uno de dichos ganadores co ... Ver más

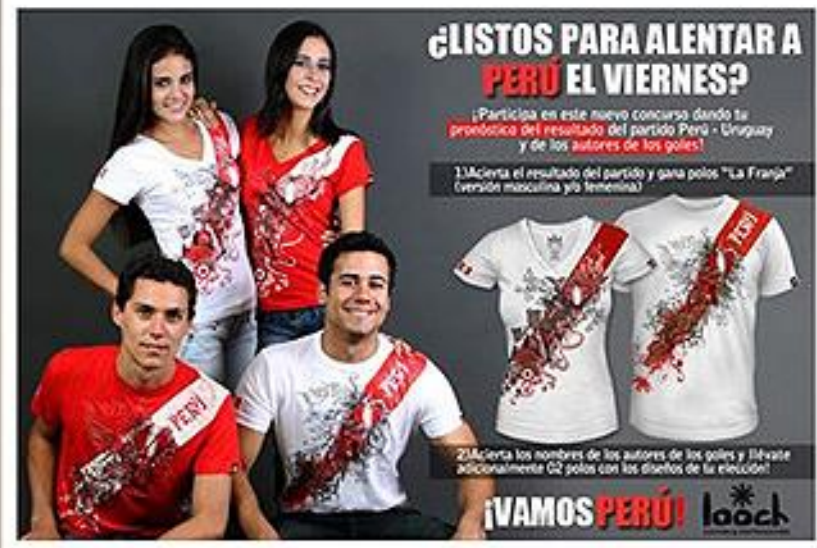

Fig. 31. Concurso con motivo de un partido de fútbol

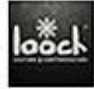

LOOCH $\otimes$ Cultura \& Contracultura

24 de mayo de 2013 . (2)

¿Reconoces a estos dioses? jComparte la imagen, participa y gana un cupón por $\$ / 200.00$ en productos!

Descarga la imagen haciendo click derecho. En dicha imagen aparecen vistas parciales de algunos de nuestros diseños, los cuales presentan a dioses o deidades que corresponden a ... Ver más

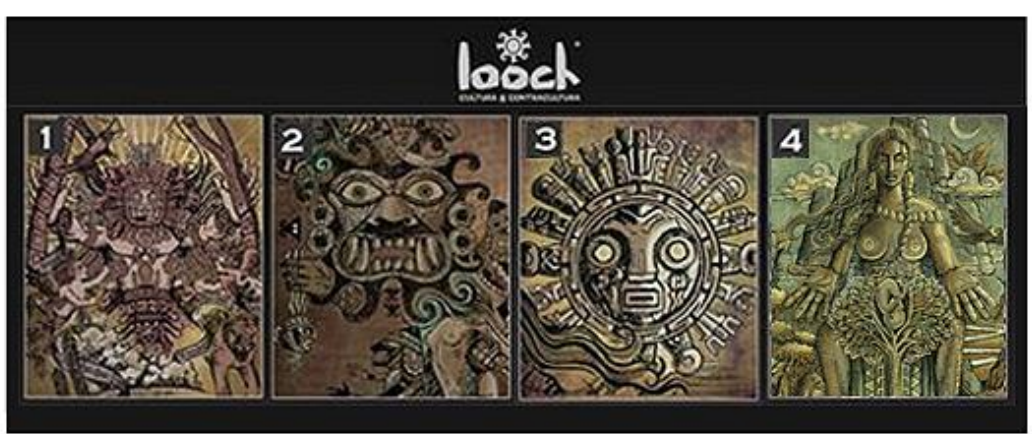

Fig. 32. Concurso de identificación de deidades 


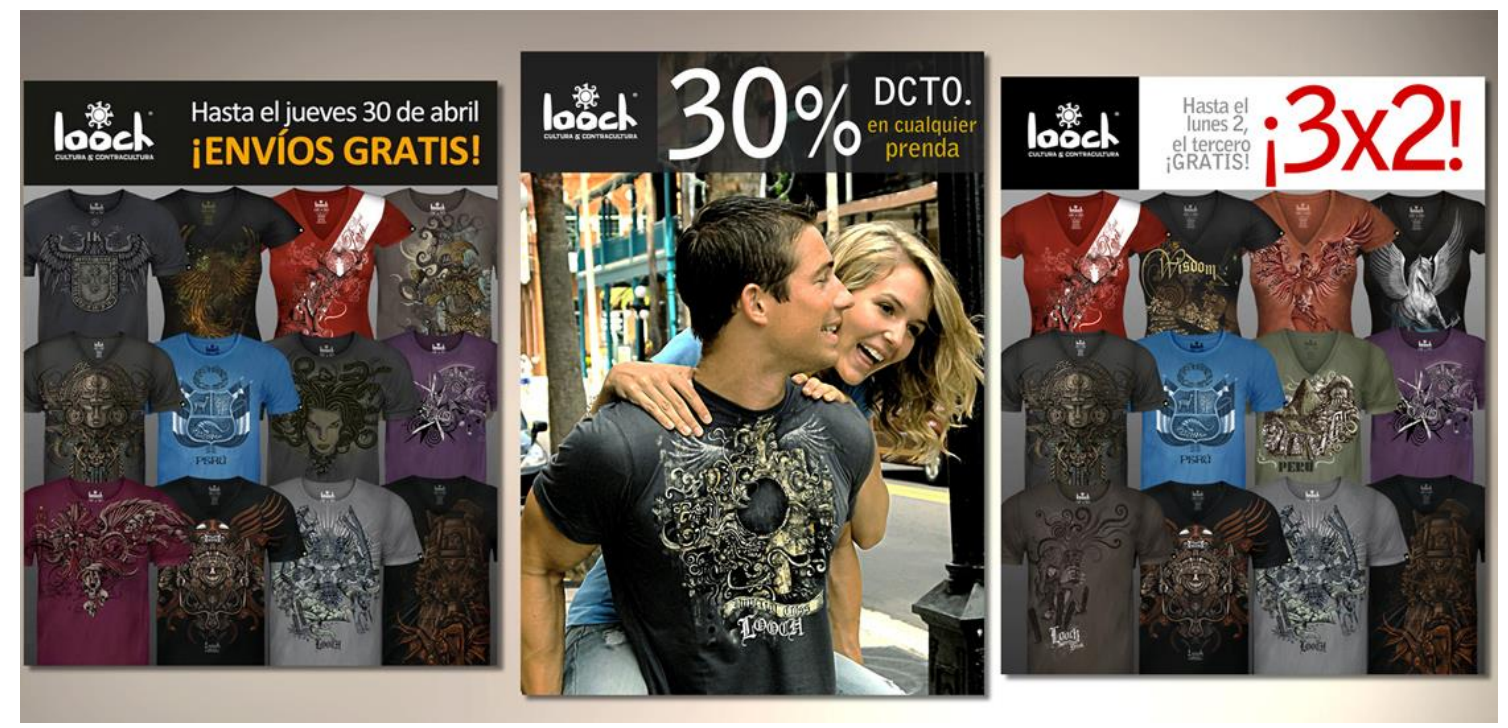

Fig. 33. Campañas publicitarias: envíos gratis, 30\% de descuento y 3x2

\section{Participación en ferias y eventos}

La marca ha participado en ferias tanto a nivel nacional como en el extranjero (EEUU, Italia y Francia). La figura 34 muestra el stand de la marca en la feria Latinoamericando, llevada a cabo en Milán, Italia, en el año 2011. La figura 35 muestra la participación de la marca con una impulsadora en un evento promocionado por PromPer en la ciudad de Lima.

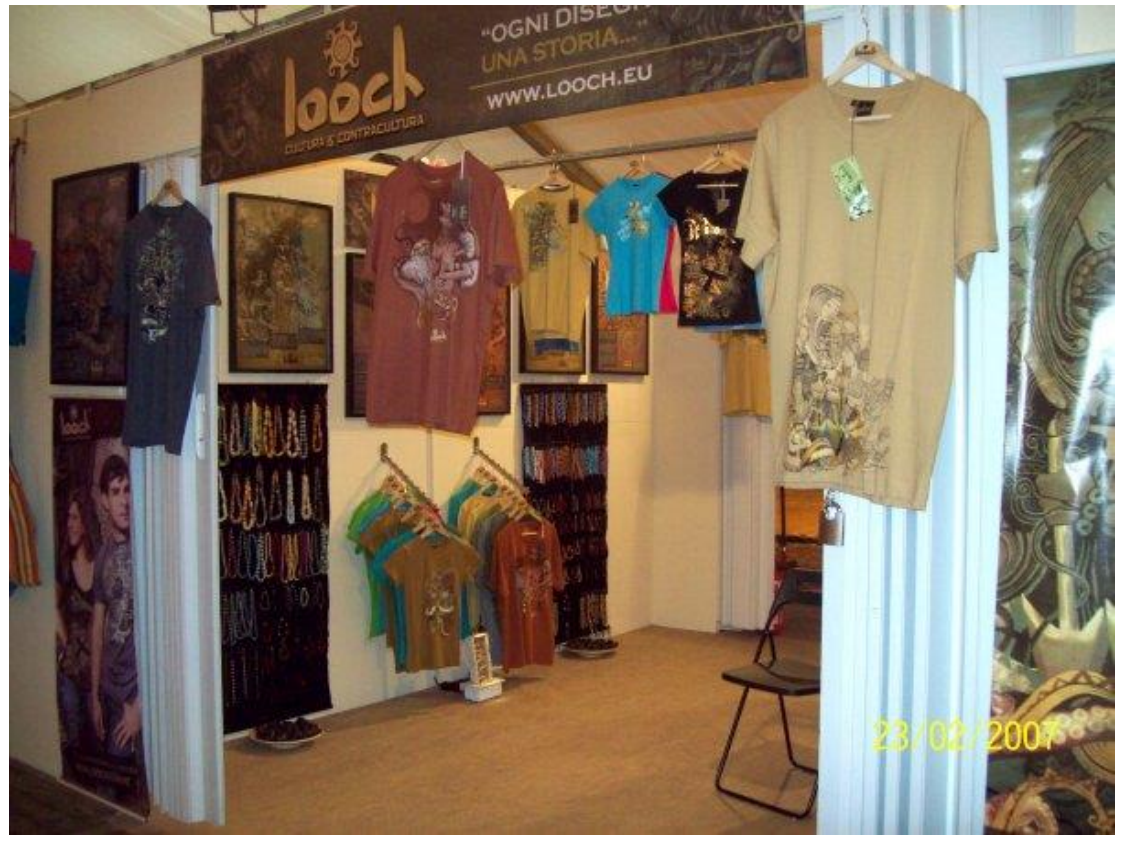

Fig. 34. Participación de Looch en la feria Latinoamericando, Milan, Italia, 2011 


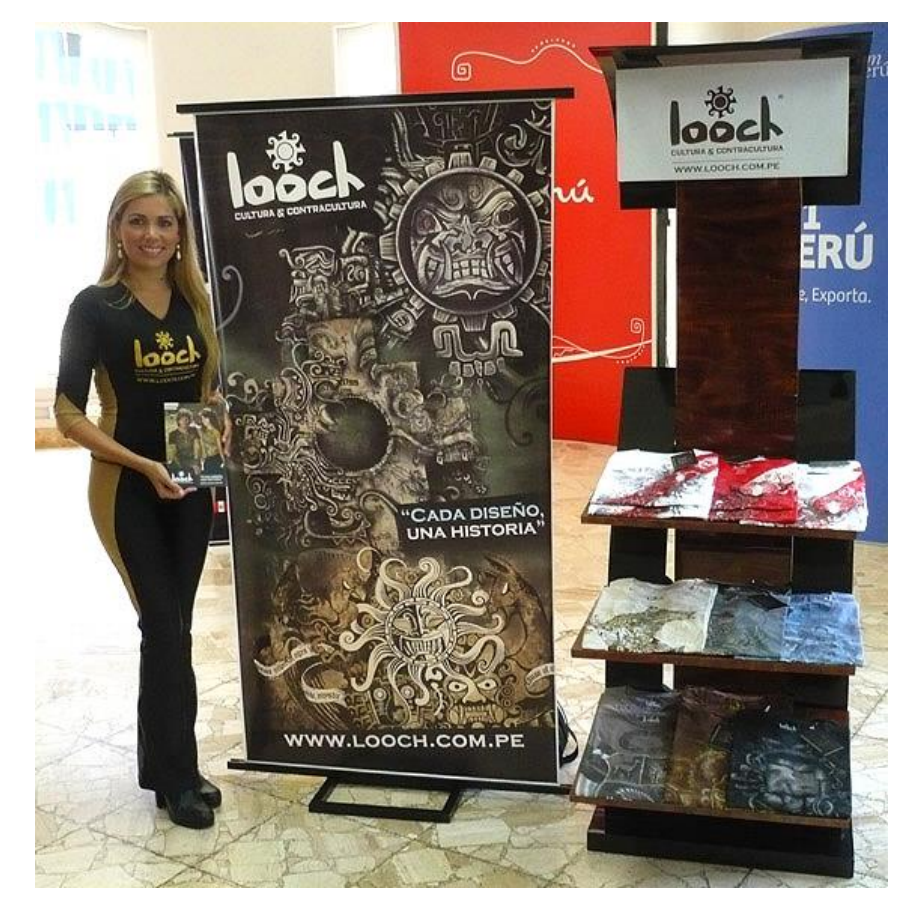

Fig.35. Participación de Looch en un evento patrocinado por PromPerú

\section{Co-Branding}

El co-branding o alianza estratégica de marcas es una estrategia de marketing cuyo valor diferencial reside en la asociación de marcas con el fin de lograr un impulso del valor de éstas. En tal sentido, es de relevancia señalar que en dichos convenios, la identidad corporativa de los participantes se verá afectada en vista que existe un influjo de mutuo entre éstos cuando se genera el vínculo comercial.

Un ejemplo de co-branding se muestra en la figura 36. La imagen corporativa de Looch se fusionó con la correspondiente de la marca Candelaria con el objetivo de impulsar una promoción en la cual, por la compra de dos polos, el cliente podía acceder a llevarse un 4-pack de cervezas artesanales de la línea "La Patriota" de Candelaria completamente gratis. La promoción fue impulsada por la red social Facebook. 


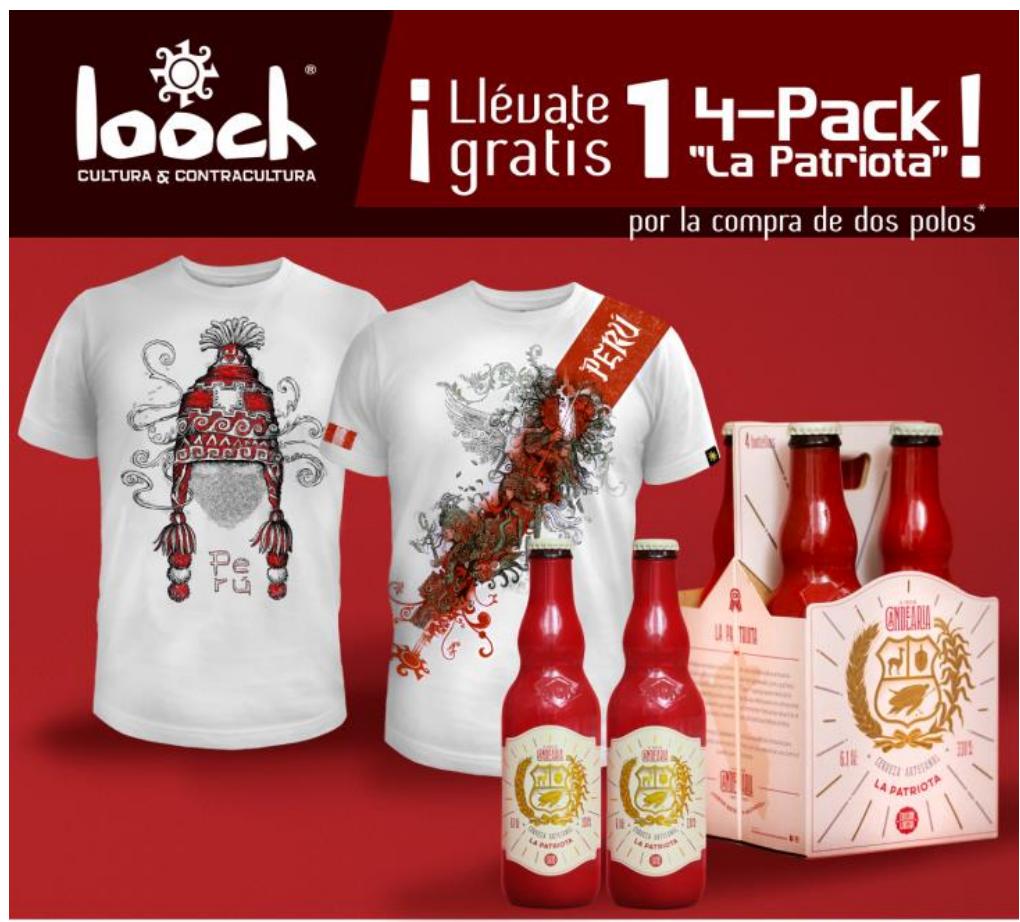

Tomar bebidas alcohólicas en exceso es dañino

Fig. 36. Publicidad de co-branding con Candelaria

\section{Auspicios}

Se han consolidado relaciones amicales con artistas cuyos intereses se alinean a la misión de la marca. En favor de la promoción de la labor que éstos realizan, la marca ha brindado prendas de vestir o aportes económicos. La figura 37 muestra el evento de lanzamiento de la Guitarra Perú, construida por el músico Gonzalo Belmar, siendo Looch uno de los auspiciadores. Por otro lado, la figura 38 expone un trabajo de pintura pavimental 3D con el diseño Danzaq de Looch, pintado por el artista de anamorfosis César Paredes Pacora, a quien se le aportó económicamente para promover su arte. 


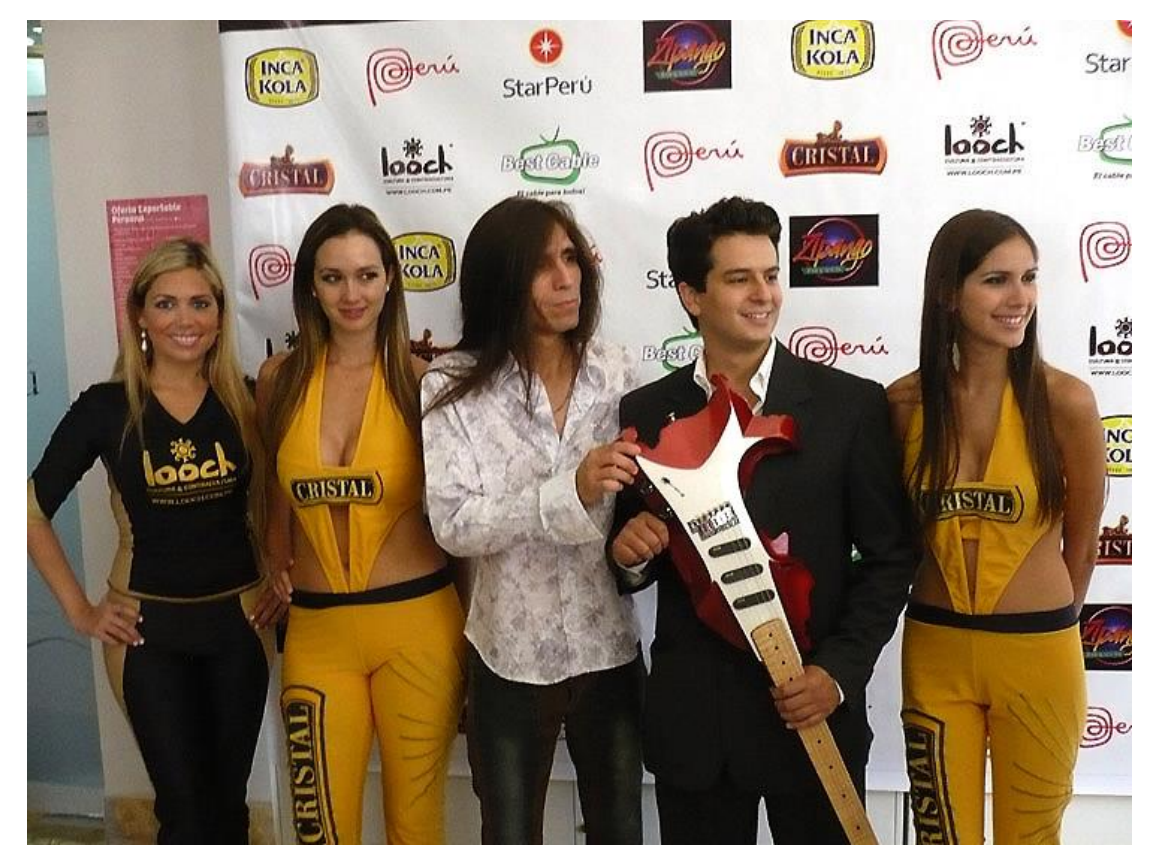

Fig. 37. Auspicio para el evento de lanzamiento de la Guitarra Perú

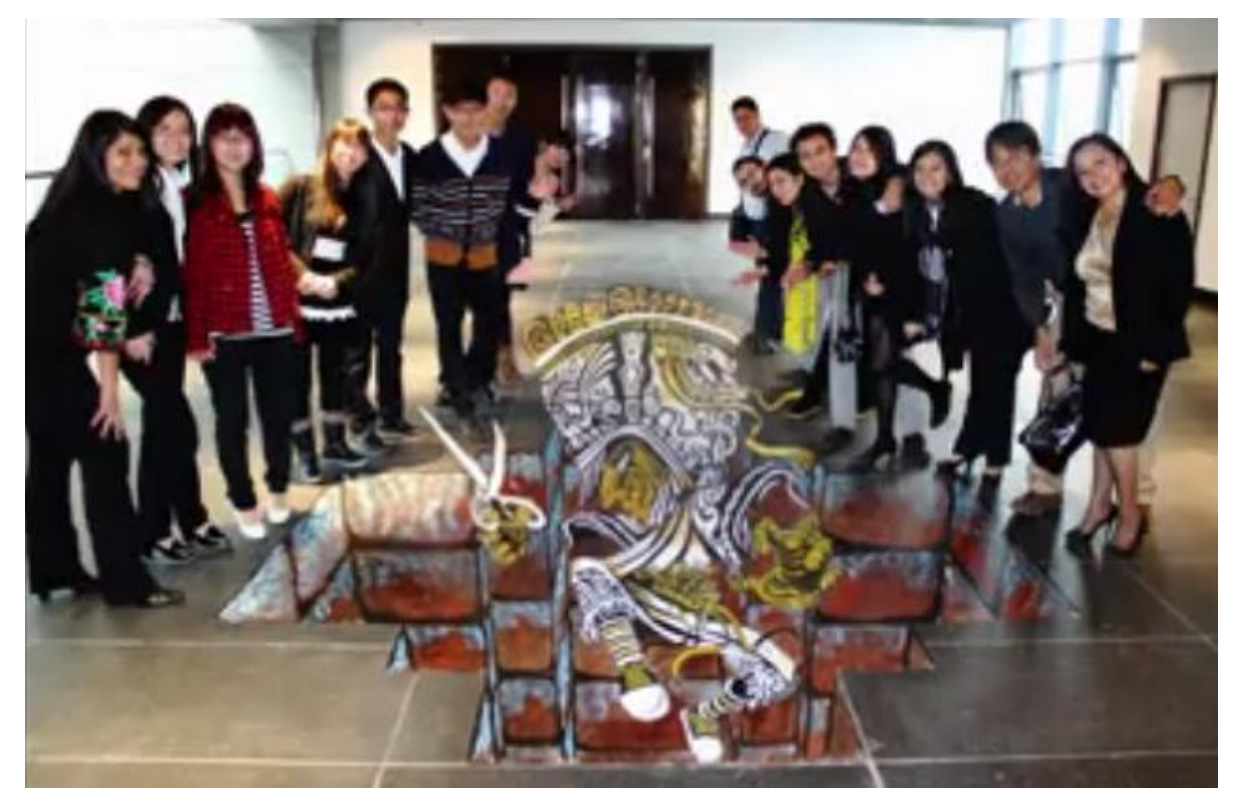

Fig. 38. Reproducción en anamorfosis del diseño Danzaq

\section{Canjes publicitarios con líderes de opinión}

El ejercicio del liderazgo, en la formación de pueblos y culturas en la antigüedad, estuvo reservado para aquel que era capaz de ejercer dominio haciendo uso de la fuerza o para aquel que, debido a su sabiduría tenia las 
cualidades necesarias para influir y guiar a la gente. En la actualidad, dicho ejercicio se obtiene de diversas fuentes a las luz de la aparición de "conductores sociales, de individuos influyentes, capaces de dirigir, manipular, persuadir a los demás, ejercer autoridad, mandar y ser obedecidos" (Rivadeneira, 1986: 197). Dentro de esta clasificación de conductores o individuos influyentes, existen lideres naturales debido a su apariencia física, su talento o su intelecto en relación a alguna disciplina o quehacer en particular en que se han desarrollado, forjando aquella imagen que les ha permitido llegar al sitial que les concierne.

El marketing encuentra una conexión de suma valía entre dichos líderes -dado el poder que estos ejercen sobre las masas- $y$ tanto con los productos que una marca genera, como con su imagen misma. El acordar canjes o convenios publicitarios entre un líder y una marca, la aprobación natural cedida por cierto público hacia el líder se traslada, de manera inconsciente, hacia el repertorio de productos y servicios que ofrece la marca.

Looch ha efectuado esta opción de marketing con diversos artistas y comunicadores a modo de canjes publicitarios. La exposición de estos líderes de opinión usando las prendas de la marca dentro del ámbito en que se desenvuelven, se muestra en la figura 39. 

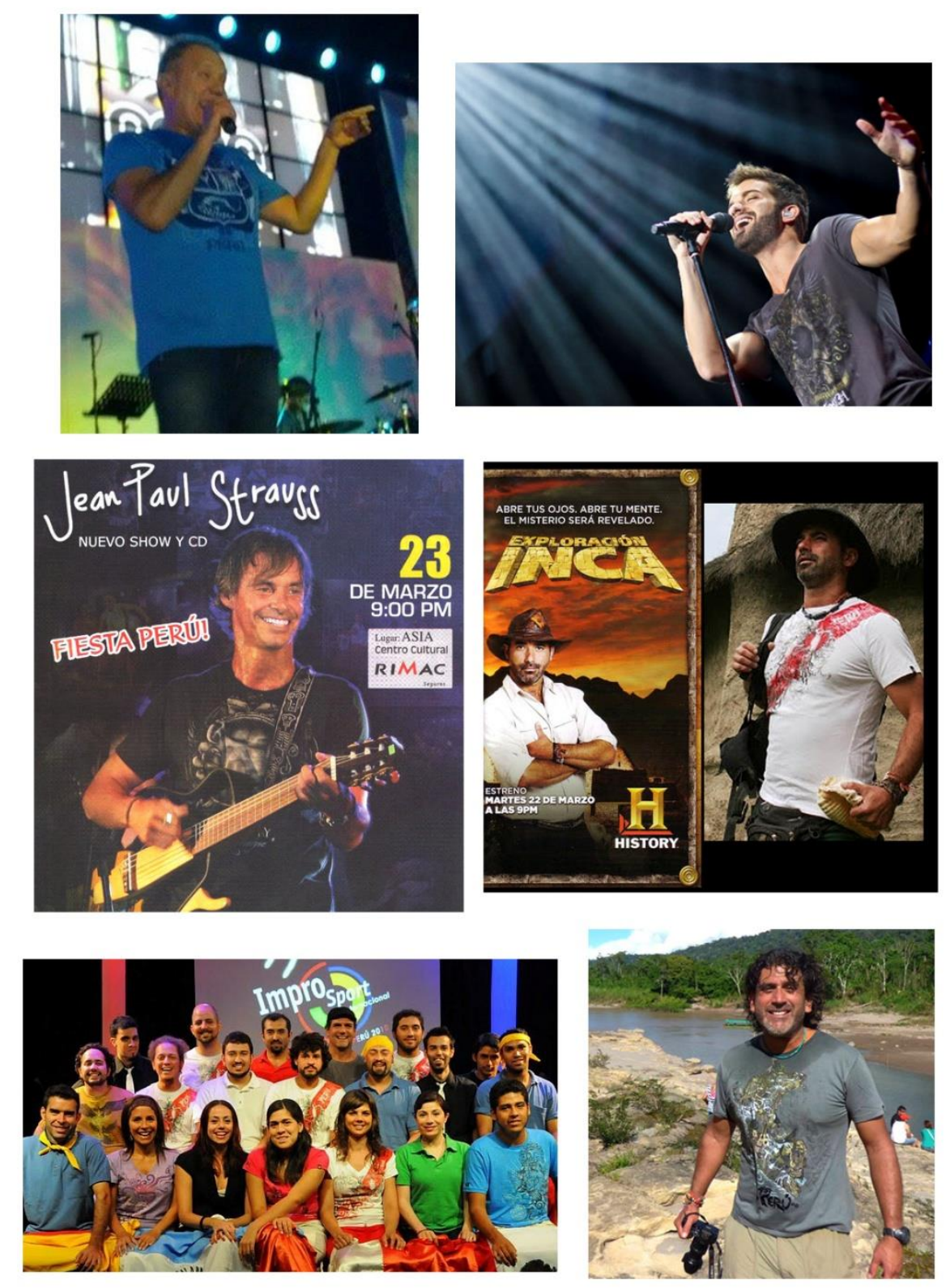

Fig. 39. Canjes publicitarios con líderes de opinión

\section{Video de marca}

Para efectos de construcción de patrimonio y valor de marca, se realizó un video en 3D (Fig. 40) de medio minuto de duración en el que se visualizan los diseños sobre las páginas de un libro. Al correr las paginas, el libro se desvanece y emergen tres polos con los diseños estampados. El video cierra con el logotipo de la marca y una invitación a visitar sus redes sociales. El video deja abierta la posibilidad de explotar las ideas o los conceptos que ofrece el proyecto haciendo uso de las herramientas que ofrece el 3D. 

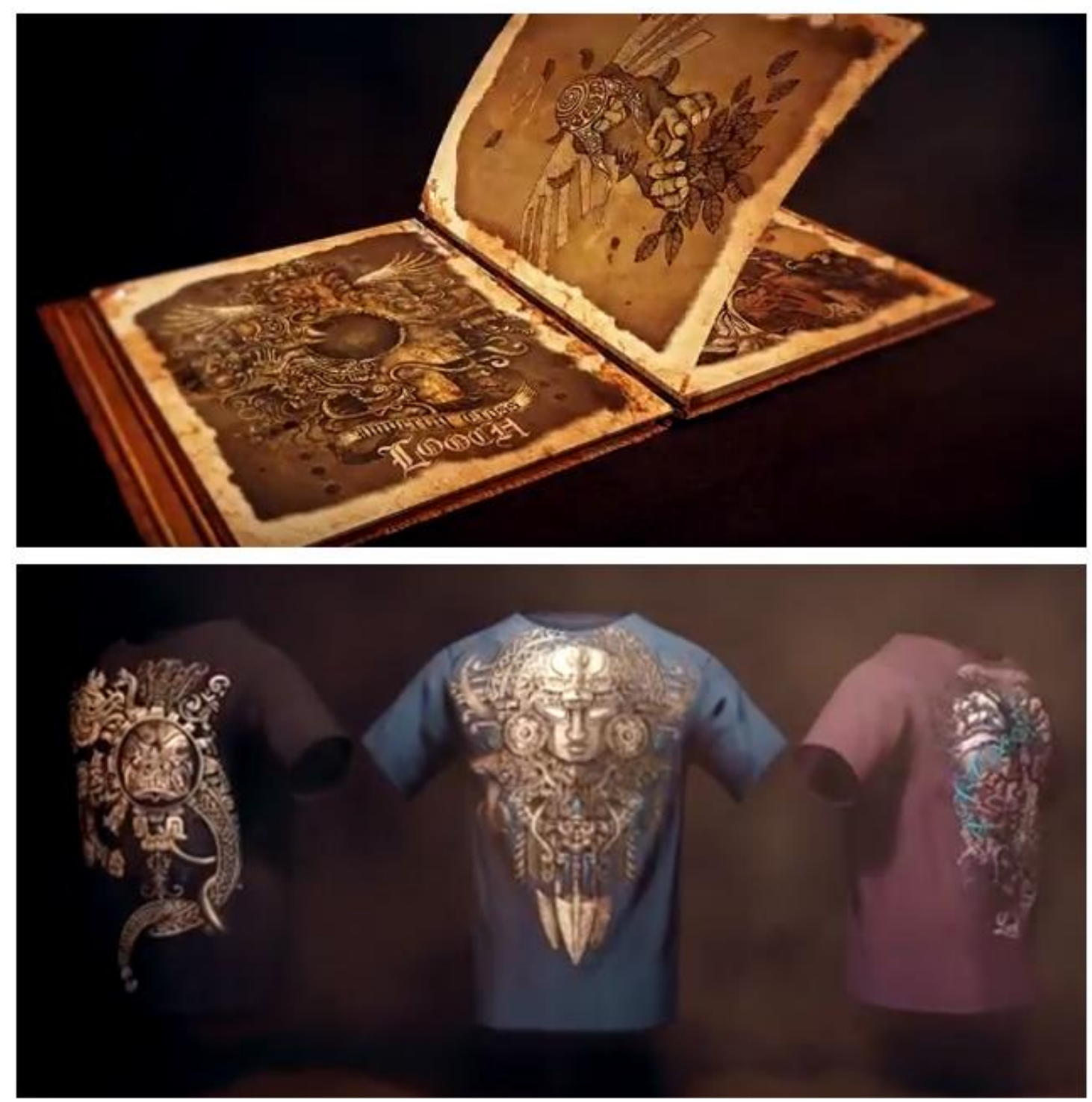

Fig. 40. Video publicitario 3d 


\section{CAPITULO VI}

\subsection{Análisis de los resultados}

Con fines de medir la efectividad del objetivo pedagógico del proyecto y medir su alcance en el público objetivo, se hizo uso de las herramientas estadísticas que proveen algunos medios digitales como Facebook o Google.

Dado que cada uno de los diseños producidos, junto con su información textual, guardan reacciones diferentes en distintas plataformas, se tomará como caso de análisis al diseño relacionado al personaje mitológico Amaru, el mismo que, según las encuestas realizadas explicadas anteriormente, no goza del conocimiento del público objetivo. La marca procede a efectuar un estudio del mismo a nivel iconológico para luego reformularlo gráficamente con sus propios códigos visuales con el fin de exponerlo o visibilizarlo.

El Amaru es un dios importante en la mitología y religión andina precolombina asociado al sol y la luna además de estar profusamente representado en la época inca y pre-inca (Lizárraga: 67). Con la llegada de los españoles, se le relacionó con la figura mitológica de los dragones, añadiéndosele al imaginario andino, contenidos europeos.

Su reinterpretación iconográfica se muestra en la figura 16. El diseño, posteriormente, fue estampado en polos para caballeros según la técnica de la serigrafía previamente descrita. Una vez que la producción estuvo disponible, se elaboró un concurso en el cual se invitó al público a no solo dar con el nombre del personaje, sino también a brindar información relacionada a éste, estimulando la investigación de los participantes. Es así que la respuesta correcta y el valor agregado relacionado a la historia del personaje serían considerados para definir al ganador del concurso, el mismo que ganaría una prenda estampada con el mencionado motivo. El concurso fue publicado en junio del 2012, según muestra la figura 41. La publicación se impulsó invirtiendo una cantidad económica, efectuando previamente una segmentación del público según las consideraciones que provee dicha red social. Tuvo 2,565 reacciones, y fue compartido 559 veces. 
¡Responde y participa de este concurso!

En el diseño adjunto aparece una deidad andina con cabeza de auquénido, cuerpo de serpiente alada y cola de pez, habitante de los lagos y los andes. Su simbolismo dentro de la cosmovisión andina contempla al agua, los rayos, la sabiduria, la fuerza. ¿Cuál es el nombre de este monstruo mitológico andino?(Se tomará en consideración el valor agregado de la respuesta).

Las respuestas correctas participarán en un sorteo. El(la) ganador(a) S... Ver más

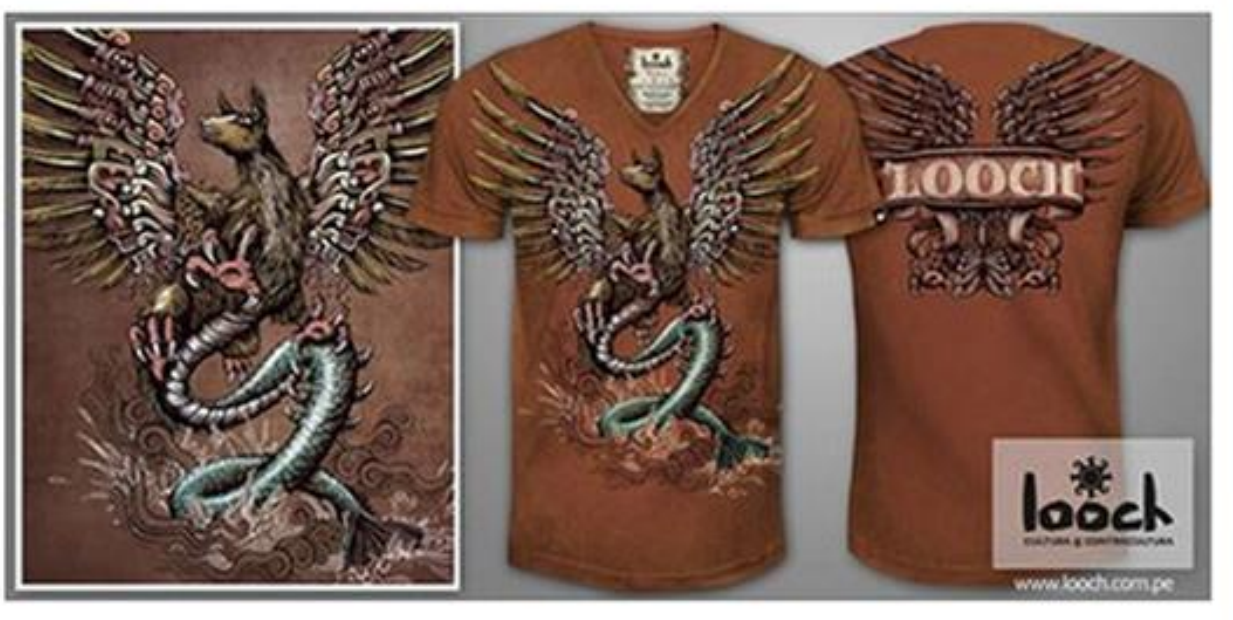

Fig. 41. Concurso de identificación de personaje impulsado en Facebook

Se revisaron los comentarios dejados por el público y siete días después, ya concluido el tiempo estipulado por el concurso, se publicó el nombre del ganador, según muestra la figura 42 (el concurso fue impulsado junto con otros concurso de características similares, en el que el motivo era las flores de Cantuta y se premiaba con una prenda para damas) 
*. LOOCH® Cultura \& Contracultura

18 de junio de 2012 .

Gracias a todos por su participación en el último concurso.

Las nombres de los diseños expuestos son-como bien han respondido en casi la totalidad de los mensajes- el Amaru y las flores de Cantuta.

Han habido muchas respuestas que no sólo se han limitado a responder la pregunta, sino también a contarnos detalles de los diseños de forma ilustrativa contemplando mitologias o leyendas asociadas,

características, origen, morfología, etc. Se han seleccionado todas las respuestas con valor agregado y entre ellas se ha procedido al sorteo respectivo resultando ganadores:

1) @Mario Murguía (ganador de un polo con el diseño "El Amaru") y @Adriana Villafuerte (ganadora de un polo con el diseño "Flores de Cantuta")

En breve estaremos coordinando la entrega de los premios a los 2 ganadores. Felicitaciones a ambos!

Pronto estaremos publicando mas concursos y promociones en este espacio.

Saludos!

$\mathrm{LOOCH}$

Fig. 42. Publicación de ganadores del concurso de identificación de personajes

El concurso produjo un intercambio de opiniones con el público objetivo en el que se comprobó no solo una asimilación de la historia detrás del personaje, sino también una identificación cultural y un vínculo de apropiación con el mismo. Algunos de estos comentarios se muestran en la figura 43.

Ernesto Trujillo Santos Es la Serpiente Alada o el Dragon Andino, cuyo rostro es alargado al igual que de una llama.

Me gusta Responder

Anace Ascoy Ganoza Me encanta, orgullo de mi tierra ०००

Me encanta - Responder - Mensaje

Alan García Aquino Asu, q tal historia, simplemente bravaza... Saludos

Me gusta Responder

Fig. 43. Registro de algunos de los comentarios al concurso 
La expansión del imaginario y de la cultura visual relacionada a dicho personaje se puede comprobar con las búsquedas de imágenes en Google. La ilustración aparece repetidas veces usando diferentes filtros de búsqueda, así como la foto de la prenda estampada con dicho motivo, promovida por la marca. La imagen 44 muestra un ejemplo en que el diseño aparece en los resultados de búsqueda del Google. Además, fue tomado por una web relacionada a mitos y leyendas, dentro de la cual se expone la ilustración junto con una breve descripción textual en referencia al personaje.

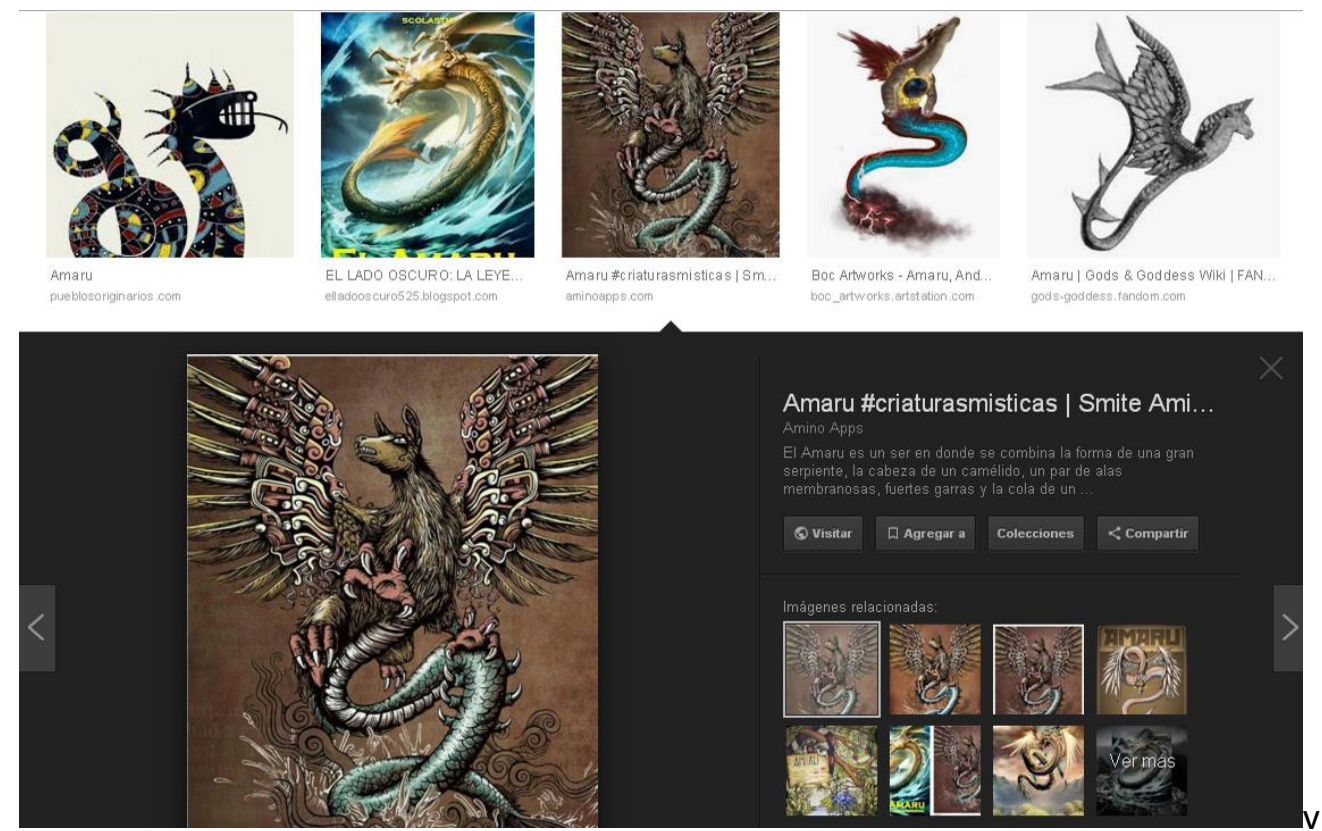

Fig. 44. Resultado de búsqueda de imágenes al filtro "Amaru"

De igual forma, en la red social Pinterest, el diseño aparece compartido en distintos tableros, según muestra la figura 45. 
๑

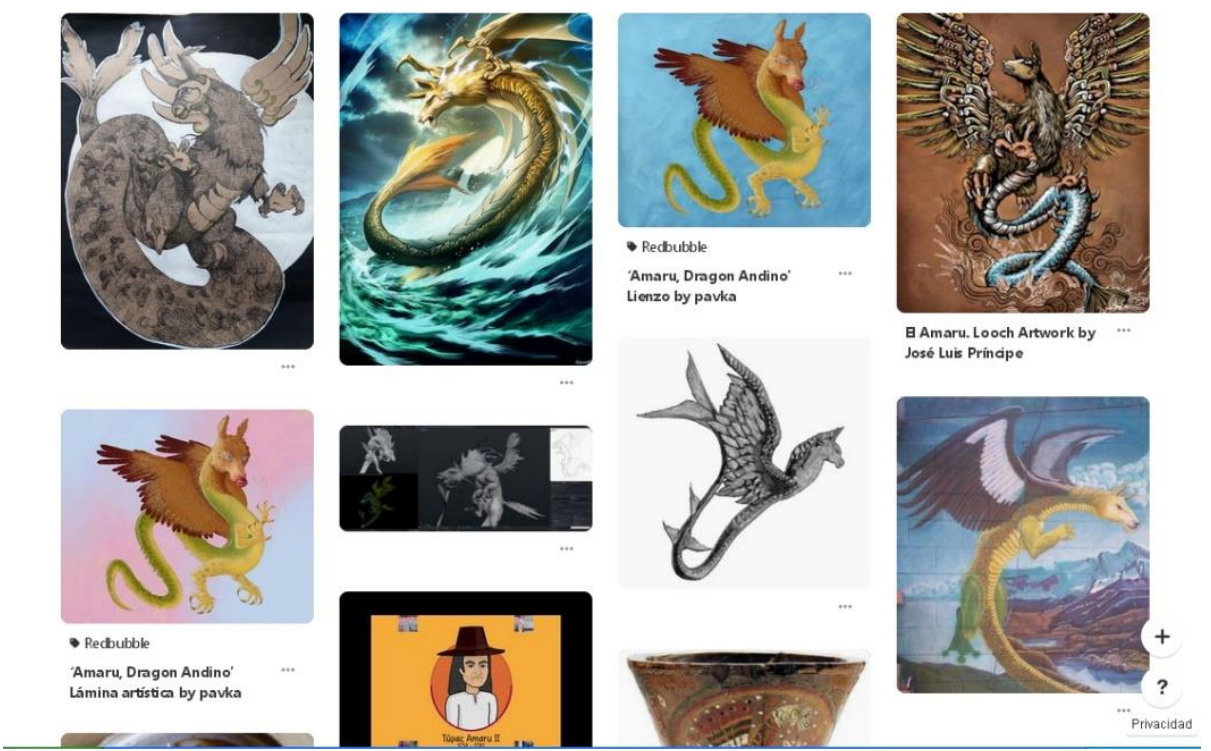

Fig. 45. Resultado de búsqueda de imágenes al filtro "Amaru" en Pinterest

El tránsito o flujo del diseño en las búsquedas en internet puede comprobarse en la relación que se aprecia entre Wikipedia y la ilustración una vez efectuada la búsqueda en Google, según muestra la figura 46.

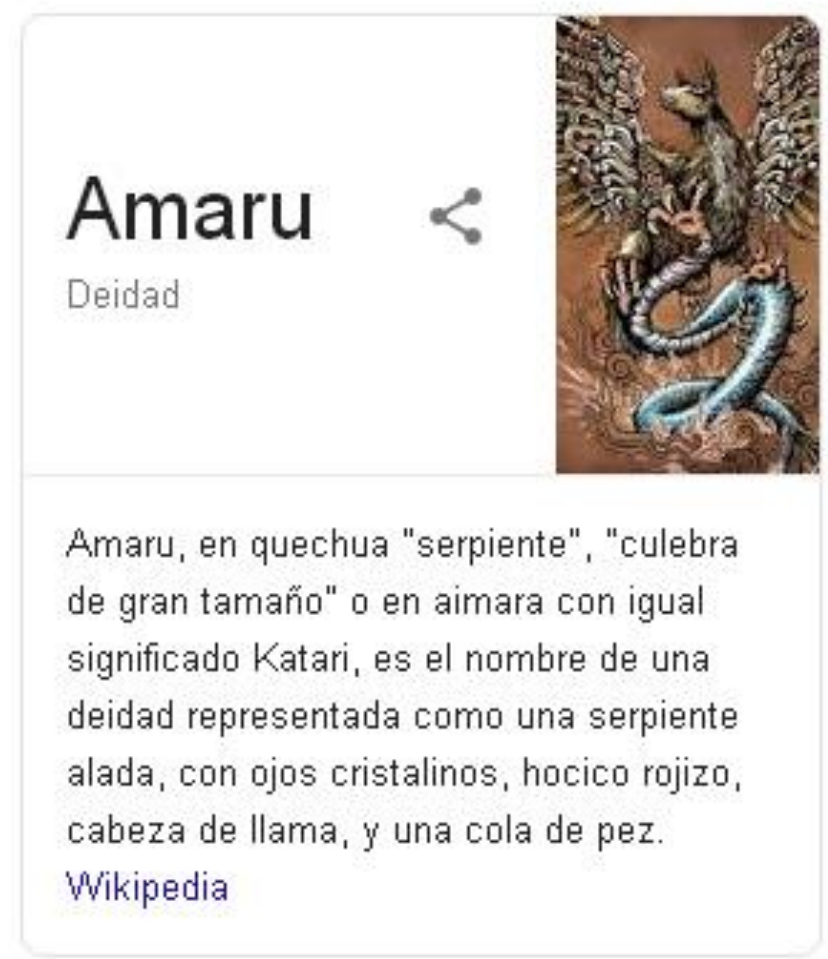

Comentarios

Fig. 46. Vinculación del diseño Amaru de Looch con Wikipedia 
El caso de estudio descrito con el diseño Amaru ha tenido resultados similares con los demás diseños producidos por la marca. Cada uno de estos ha experimentado reacciones de diversa índole en distintas plataformas, por lo que se comprueba no solo la expansión del imaginario y la cultura visual de los personajes o temas propios de la mitología ancestral de los pueblos originarios peruanos, sino también un compromiso en cuanto a la divulgación de los mitos, leyendas e historias que se han construido culturalmente en torno a éstos. Se evidencia entonces, un resultado favorable en cuanto a los objetivos trazados.

\subsection{Conclusiones}

1. El proyecto expuesto no pretende solucionar los problemas y las dificultades culturales y educacionales que han sido motivo de la presente investigación, sino más bien contribuir a la mitigación del problema aportando con la difusión de todas aquellas expresiones culturales ancestrales peruanas que, debido a diversas razones, no han sido visibilizadas al público objetivo. En ese sentido, el presente trabajo será expuesto como un proyecto a los actores definidos en la investigación (instituciones públicas y privadas), con la finalidad de obtener alianzas estratégicas, impulsión y/o financiamiento, con lo cual se pueda aspirar a una mejora continua del mismo.

2. Las propuestas ilustradas para atender las problemáticas $y / 0$ necesidades de determinado público, pueden configurarse o expresarse de múltiples maneras, presentando diversos discursos gráficos. La retórica visual ilustrada y los códigos visuales usados en la propuesta del presente proyecto exponen una narrativa particular que responde a los intereses de un público objetivo en particular dentro del rango comprendido entre las edades de 20 a 30 años.

3. El presente estudio describe tan solo los cimientos de un proyecto visual que aspira a expandirse hacia distintos soportes y no limitarse tan solo a 
prendas de vestir. En el corto y mediano plazo, aspira a fortalecer sus propias narrativas y brindar nuevas experiencias visuales a su público objetivo.

4. Según la evaluación de resultados, el proyecto es viable como la proyección y promoción de una nueva estética visual en función a la difusión de la iconografía ancestral peruana apelando a intereses pedagógicos, no solo para el público nacional, sino también para la imagen del Perú a nivel internacional. 


\section{Bibliografía}

\section{CASSIRER, Ernst}

1971 Filosofía de las formas simbólicas. Fondo de Cultura Económica

CASTIÑEIRAS, Manuel

2007. "Introducción al método iconográfico" Barcelona, Editorial Ariel, S.A.

CHORDA, Frederick,

1993 "Aprendiendo a mirar el arte". Zaragoza, Gobierno de Aragón y Diputación de Zaragoza.

DONDIS, Donis A.

1992 "La sintaxis de la Imagen. Introducción al método visual". Ediciones G. Gilli S.A..

HEGEL, Georg Wilhelm

2002 Estética, Libro Tercero: La forma del arte simbólico". Biblioteca de grandes pensadores.

KEMP, Martín.

2000. "La ciencia del Arte". Ediciones AKAL, Feb 16,

LEVI STRAUSS, Claude

1987 "Antropología estructural ". Paidos Ibérica

MARTINEZ MORO, J.

2004 "La ilustración como categoría: una teoría unificada sobre arte y conocimiento. Ediciones Trea, Gijòn

MORIN, Edgar 
2000 "El paradigma perdido. Ensayo de bioantropología", Barcelona, Kairós

PANOFSKY, Erwin.

2000. "El significado de las artes visuales". Alianza Editorial, Madrid

VASARI, Giorgio

2011 "Las vidas de los más excelentes arquitectos, pintores y escultores italianos“. Cátedra 


\section{ANEXOS}

Marque con un aspa el nombre que considere correcto Nombre:

Edad:
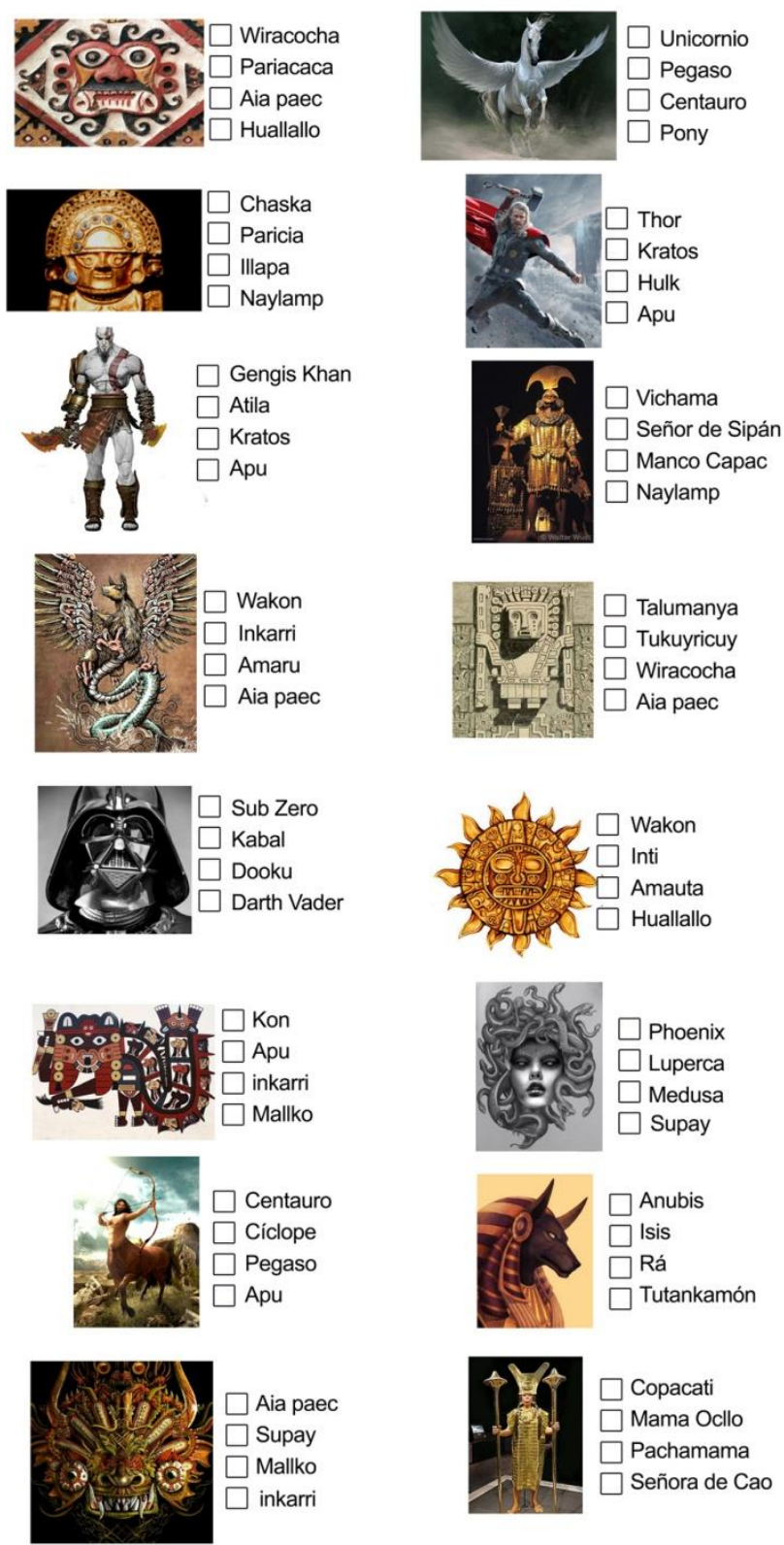

$\square$ Aia paec

$\square$ Supay

$\square$ Mallko

$\square$ Malko
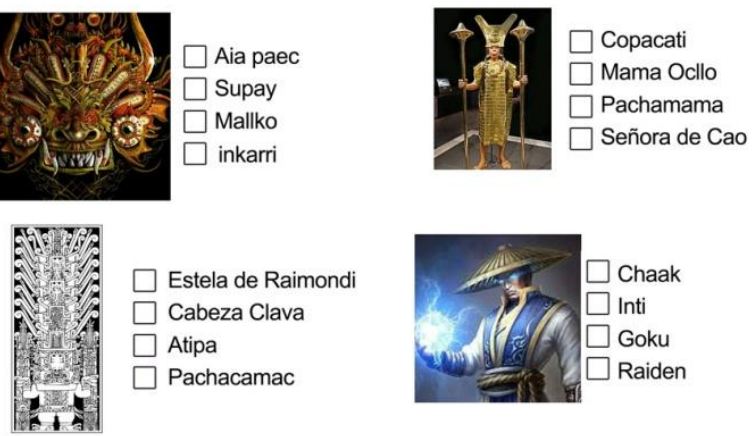

ANEXO 1 


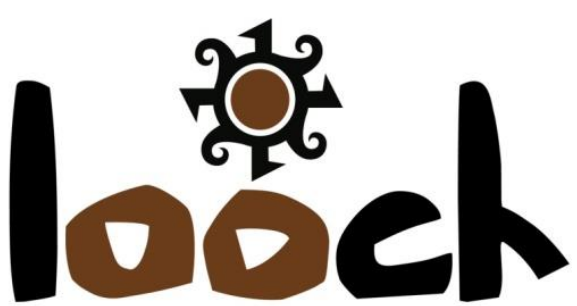

CULTURA $\propto$ CONTRACULTURA

CMYK: $40,70,90,40$

RGB: $110,66,36$

CMYK: 0, 0, 0, 100

RGB: 0, 0, 0
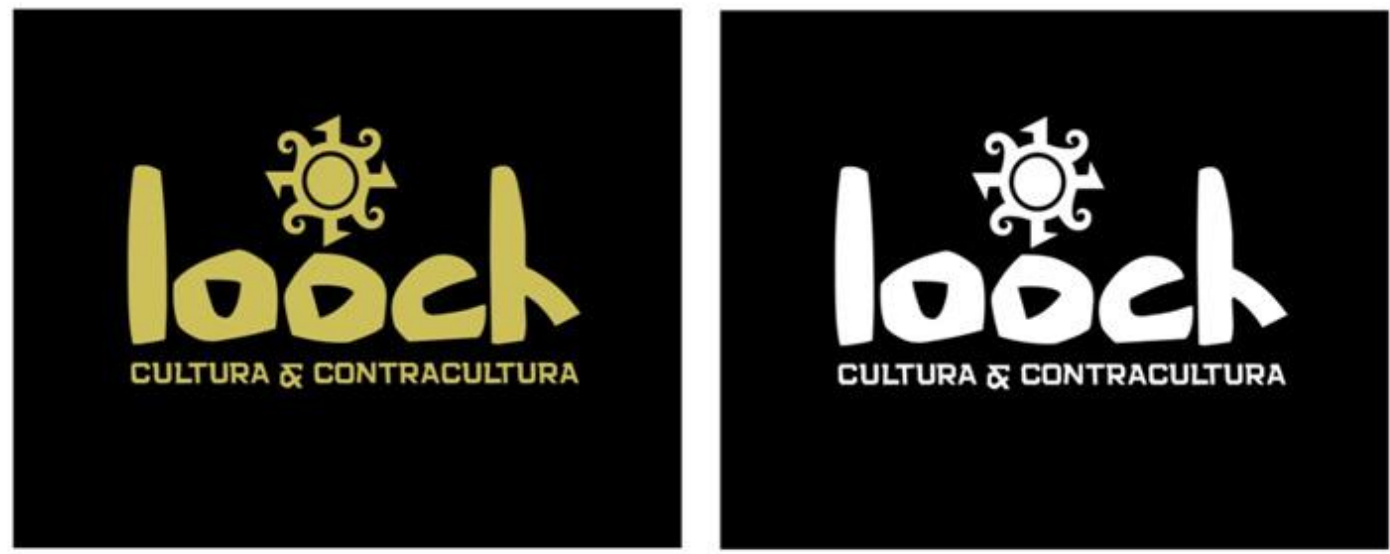

CMYK: $20,20,80,0$ RGB: 205, 192, 90

CMYK: $0,0,0,100$

RGB: $0,0,0$

CMYK: $0,0,0,0$

RGB: $255,255,255$

CMYK: $0,0,0,100$

RGB: $0,0,0$ 


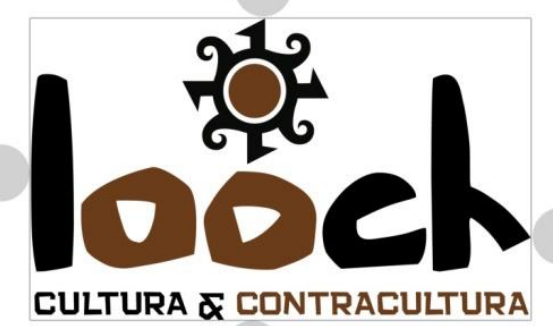

$$
=20^{2}
$$

ANEXO 2 

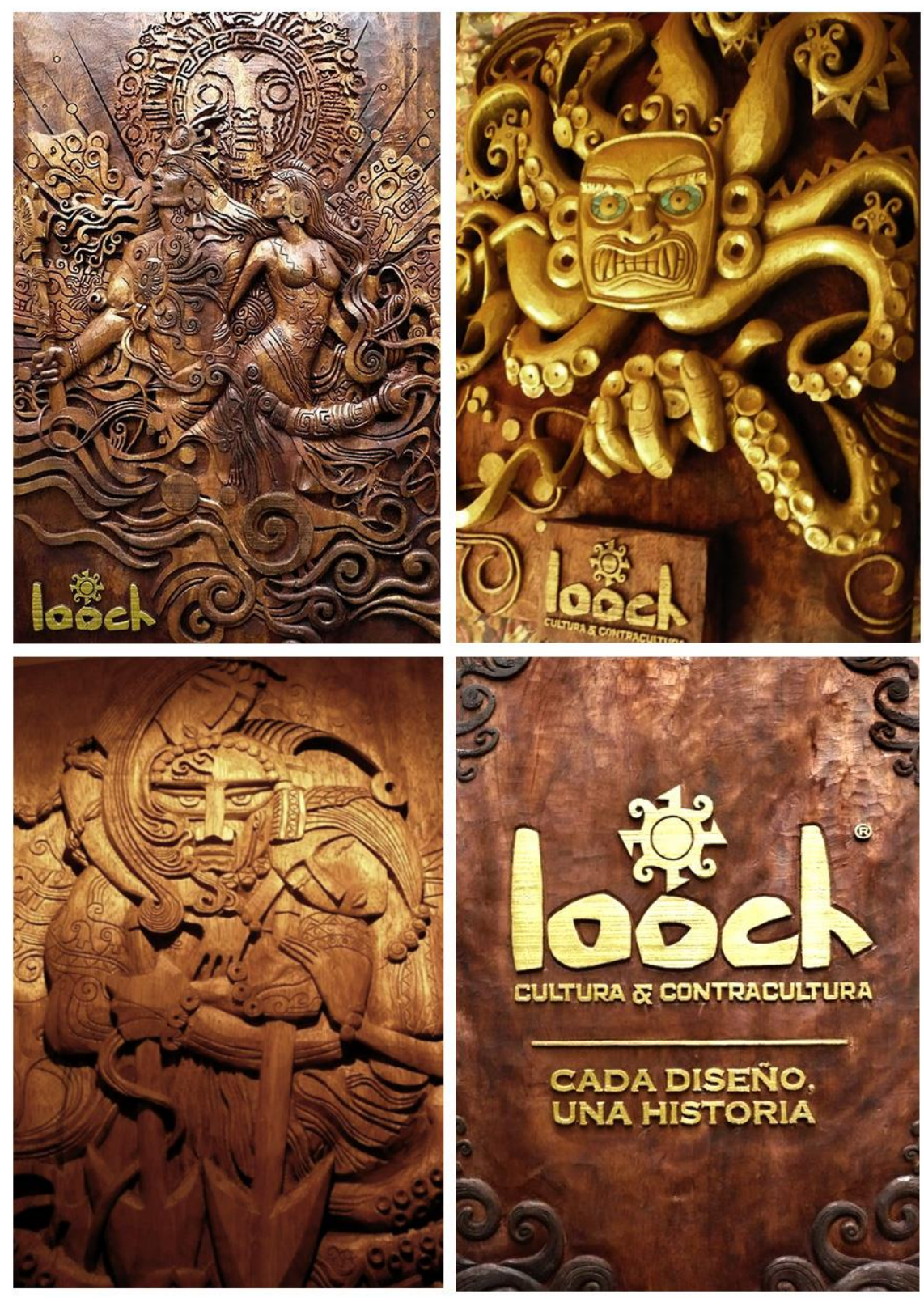

ANEXO 3 

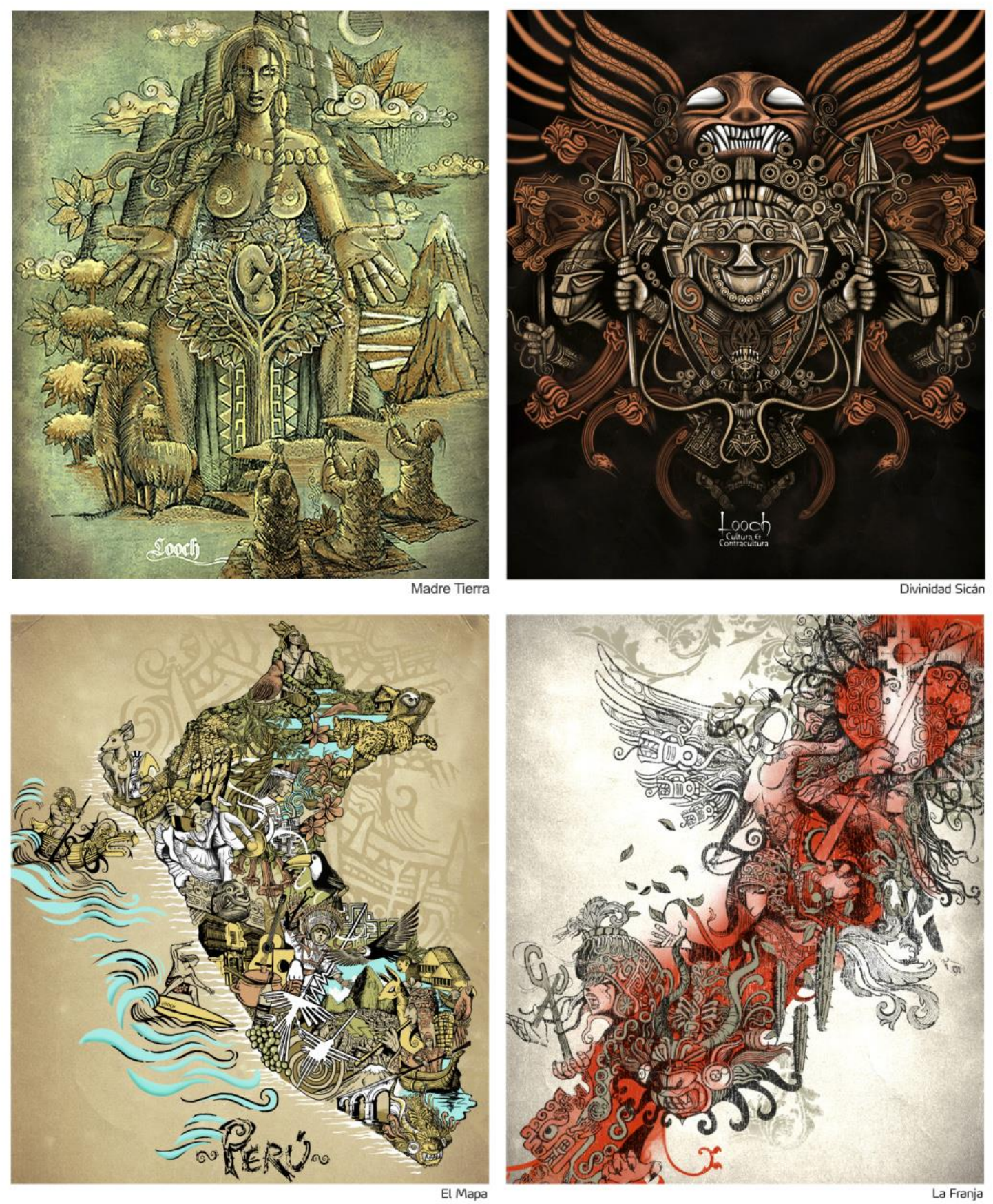

ANEXO 4 

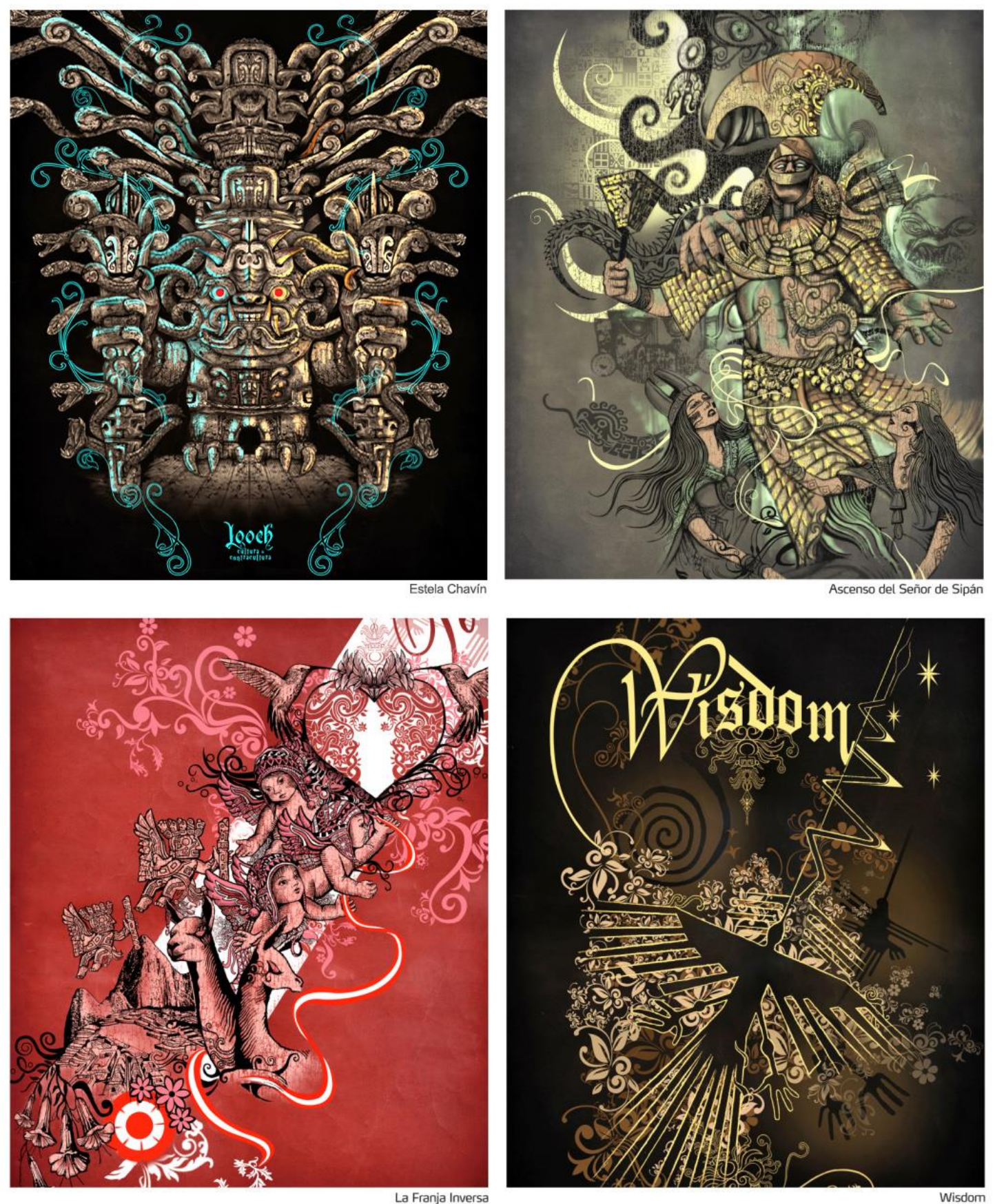

ANEXO 5 

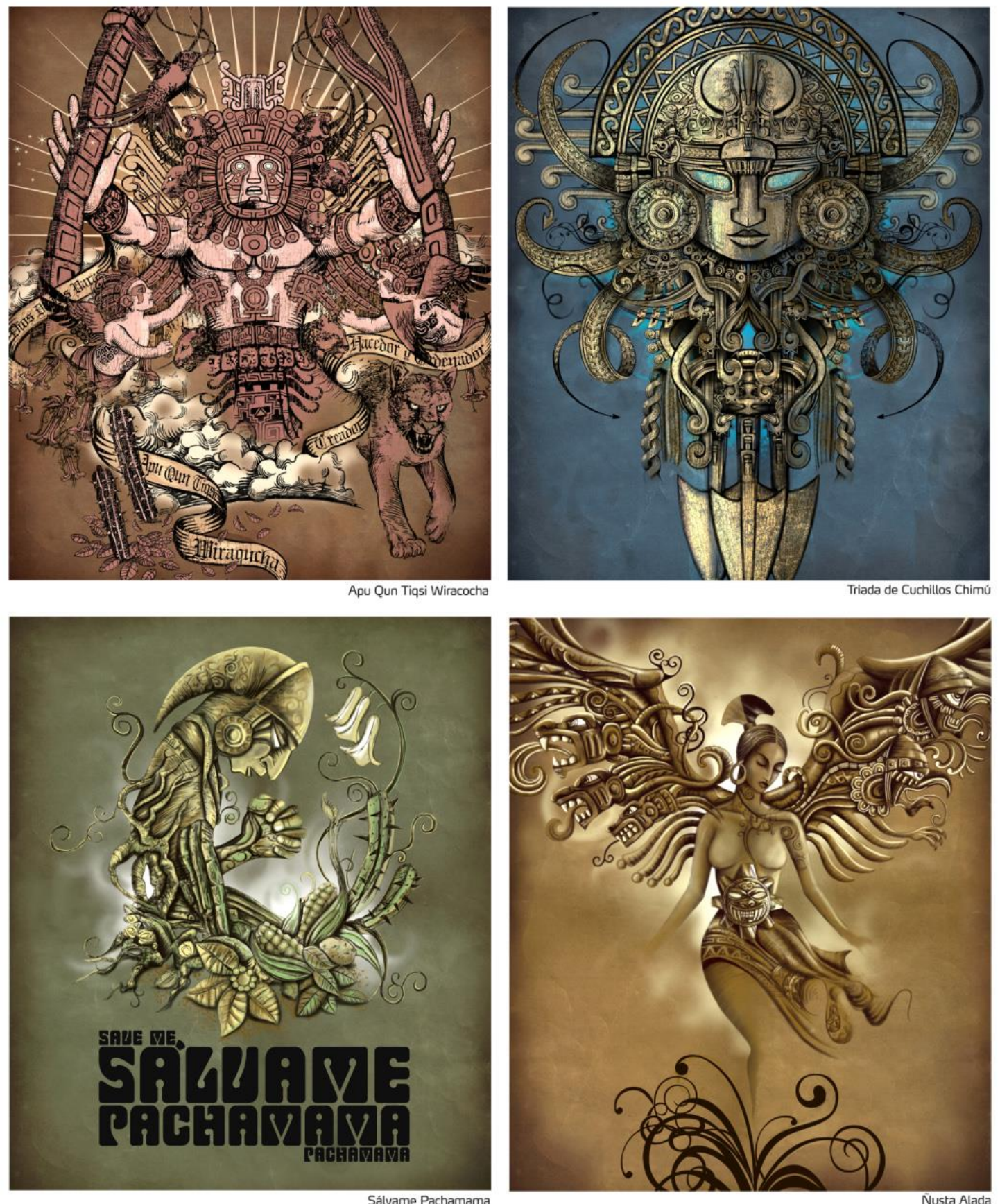

N̄usta Alada

ANEXO 6 

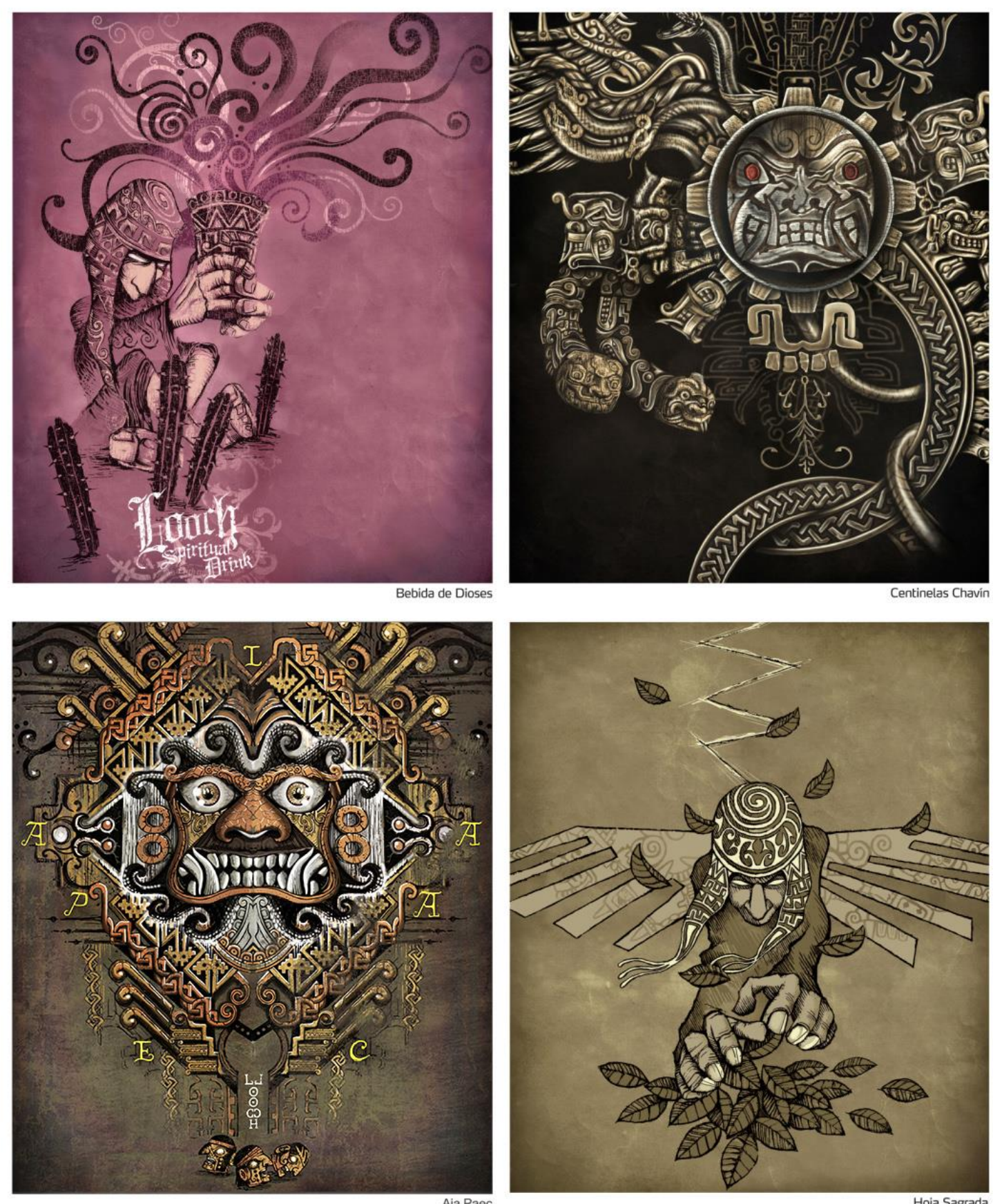

ANEXO 7 